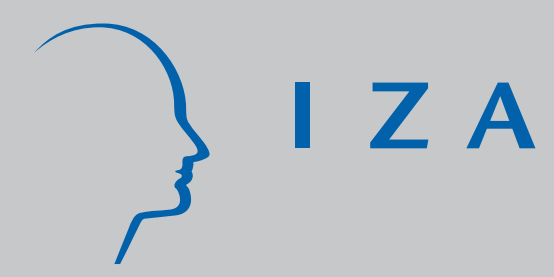

IZA DP No. 2354

The Income of the Swedish Baby Boomers

Lennart Flood

Anders Klevmarken

Andreea Mitrut

October 2006 


\title{
The Income of the Swedish Baby Boomers
}

\author{
Lennart Flood \\ Göteborg University \\ and IZA Bonn
}

Anders Klevmarken

Uppsala University

and IZA Bonn

Andreea Mitrut

Göteborg University

\section{Discussion Paper No. 2354 \\ October 2006}

\author{
IZA \\ P.O. Box 7240 \\ 53072 Bonn \\ Germany \\ Phone: +49-228-3894-0 \\ Fax: +49-228-3894-180 \\ E-mail: iza@iza.org
}

\begin{abstract}
Any opinions expressed here are those of the author(s) and not those of the institute. Research disseminated by IZA may include views on policy, but the institute itself takes no institutional policy positions.
\end{abstract}

The Institute for the Study of Labor (IZA) in Bonn is a local and virtual international research center and a place of communication between science, politics and business. IZA is an independent nonprofit company supported by Deutsche Post World Net. The center is associated with the University of Bonn and offers a stimulating research environment through its research networks, research support, and visitors and doctoral programs. IZA engages in (i) original and internationally competitive research in all fields of labor economics, (ii) development of policy concepts, and (iii) dissemination of research results and concepts to the interested public.

IZA Discussion Papers often represent preliminary work and are circulated to encourage discussion. Citation of such a paper should account for its provisional character. A revised version may be available directly from the author. 
IZA Discussion Paper No. 2354

October 2006

\section{ABSTRACT}

\section{The Income of the Swedish Baby Boomers}

This paper studies the income of Swedish households belonging to the baby boom generation, i.e. those born in the 1940-50. An international comparison as well as an historical presentation of income patterns is given. However, the main purpose is to generate the future income of the baby boom generation as they get older. A major result is that the income standard of the young-old will become much higher than that of the very old. If our simulations bear the stamp of realism, they suggest that we will see new and large poverty in Sweden among the very old in the future. The pension system contributes to this result. The "front loaded" design gives with its reduced wage indexation a higher income immediately after retirement but a much lower income at older age. From this perspective it is unfortunate that so much attention is given to the discussion of replacement rates. The replacement rate, although interesting in itself, completely misses the long run effect and just provides a comparison of incomes shortly after with incomes before retirement. If we instead focus on the relative income of older pensioners, the results become quite different. Our results challenge the conception of a sustainable pension system. If the relative income of older pensioner's drops and at the same time expenditures for health and care increase, one might wonder how the old in our society will make both ends meet. If pensions become too small to meet "minimum standards," the requirement of financial sustainability of the pension system results in an increasing financial burden on other parts of the general social protection system.

JEL Classification: $\quad \mathrm{H} 24, \mathrm{H} 31, \mathrm{H} 55$

Keywords: pension system, micro simulation, replacement rate

Corresponding author:

Lennart Flood

Department of Economics

School of Business, Economics and Law

Göteborg University

Box 640

S-405 30 Göteborg

Sweden

E-mail: Lennart.Flood@handels.gu.se

\footnotetext{
* Financial support from the Jan Wallander and Tom Hedelius Foundation for Research in Economics is gratefully acknowledged.
} 


\section{Contents:}

\section{Introduction}

2. Sweden in an international comparison

3. The Swedish experience

\section{The Swedish Micro simulation Model Sesim}

\subsection{Introducing SESIM}

4.2 Modelling of real and financial wealth in SESIM

4.3 Income generation in SESIM

\section{The Swedish pension system}

5.1. The Notional Defined Contribution Pay-as-you-go System

5.2 The Advance-funded Defined-Contribution (AF-DC) System

5.3 Occupational Pensions

\section{Retirement replacement rates}

6.1 Concepts and measures

6.2 Replacement rates for the baby boomers

6.3 Comparing different measures of replacement rates

\section{Income and poverty}

7.1 Relative income for the baby boomers

7.2 Income distribution and poverty

\section{Conclusions}




\section{Introduction}

While several studies have examined the fiscal consequences of the aging problem, there has been less focus on the level or on the distribution of income. ${ }^{1}$ The main objective of this chapter is thus to analyze the distribution of income of the baby-boom generation in comparison with earlier and later generations. Data from the Luxemburg Income Study (LIS) are used for the international comparison and data from the Linda panel for historical income earning profiles, and finally SESIM to forecast future income. ${ }^{2}$ Future income for the babyboom generation is predominantly income from pension. To better understand the relative income position of the retired we will focus on replacement rates and similar measures that relate the income of the retired to their own previous income or, respectively, with the incomes of the working generations. We intend to address the following topics:

- Incomes and pensions in Sweden compared to a few OECD countries.

- Income and labour force participation in the period 1992 to 2003.

- Future incomes under different scenarios; effects of alternative assumptions about the return on financial assets and about the age of retirement.

- The relative importance of the three pillars in the pension system - the public pensions, the occupational pensions, and the private pensions - and income from capital.

- A comparison of different definitions of replacement rates.

- Income of the pensioners in relation to the active population.

- Distribution of income and incidence of poverty.

Since SESIM is of a fundamental importance for this analysis, we also give a short presentation of this model, focusing on the wealth and income generation.

\section{Sweden in an international comparison}

According to Statistical Sweden (2003), the level of equalized disposable income in Sweden is below the average level for the EU-15 countries and the income distribution is more compressed than in most other countries. Figure 1 below presents the level of disposable income for households aged 55-90 in a sample of OECD countries. Data come from the Luxemburg Income Study (LIS) and include single as well as non-single households. ${ }^{3}$ As expected the Scandinavian countries have the most compressed income distribution. The relation between the top and bottom deciles is lowest for Norway $(2,6)$ followed by Finland and Sweden $(2,7)$. The US has the highest ratio $(5,3)$, followed by Spain $(4,6)$, Italy $(4,1)$ and the UK $(3,9)$. The high value for the US is due to a high level of income in the ninth decile (about \$57000), and not from a low first decile. The income in the first decile is approximately at the same level for several countries, the exceptions being lower incomes in Spain, only about \$5500, and Italy \$7200 and higher in Canada and Norway \$12700 and

\footnotetext{
${ }^{1}$ Recent exceptions are Mantovani et. al (2005) who use the micro simulation model EUROMOD to study pension income for the EU-15. The SHARE project reports income for 55+ in Börsch-Supan et.al (2005). Income and income distribution for older households in Sweden is also discussed in Andersson, Klevmarken and Berg (2001)

${ }^{2}$ For LIS see http://www.lisproject.org/techdoc.htm and for LINDA (Longitudinal Individual Data for Sweden), see Edin Fredriksson (2000).

${ }^{3}$ The household size is controlled for by dividing household income by the square root of number of household members. Conversion to US dollars uses OECD purchasing power parities (PPP).
} 
$\$ 11600$ respectively. The median value is highest in the US, almost $\$ 25000$, which is more than twice the median level in Spain (\$11500). Sweden with a median income of $\$ 17400$ is ranked in the middle.

A large component of the 55-90 year old retiree's income is income from pension, the size of this component depends to a large extent on previous market work and on labour force participation rates. In Table 1 LIS data have been used to classify individuals into pensioners or employed. ${ }^{4}$ There are substantial differences in cross country retirement behaviour. In the youngest age interval (51-55), Italian men stand out with almost 35\% pensioners and an employment rate of only $65 \%$. For all other countries the corresponding retirement rate is between $4 \%$ and $9 \%$. The highest employment rates for young males is in the United States (92\%), followed by Norway and Sweden. In most countries there is a strong increase in retirement after age 55. The highest share for the males in the age bracket 56-60 is in Italy (58\%) closely followed by Austria (55\%), and Finland (24\%). The lowest share is in Spain, less than $8 \%$, and for the other countries the share is somewhere between 9 and $16 \%$. For males aged 61-65 there is a clear division into two groups of countries; a high share of retired, 70-95\% - Germany, Finland, Italy and Austria- and the rest with a much lower share $34-48 \%$. Also in the oldest age group there are large differences in retirement, from the highest in Austria (100\%), Spain (96\%), and Finland (95\%) to the lowest in the United States (59\%), Norway (80\%) and Sweden (88\%).

For both males and females there are large categories not included in Table 1 namely unemployed males and house wives. For the youngest ages three countries have a female employment share below 50\% - Spain (23\%), Italy (29\%) and Austria (46\%) - in Germany and the UK the share is between $60-70 \%$ and for the rest above $70 \%$ (highest in Sweden $84 \%$ ). The cross country differences in female employment rate are substantial for the age bracket 56-60. Two groups of countries can be identified; low rates ranging from 17 to $48 \%$ in Italy, Spain, Austria, Germany and the UK, and high rates ranging from $60 \%$ to 81\% with the highest in Sweden. For the oldest the highest employment rate is found in the United States (19\%) followed by Norway, the UK and Sweden. In some countries it is possible to distinguish the self-employed as a separate category and this group stands out in terms of a late retirement age.

The female employment share plays a crucial role for the standard of living of elderly households. Countries characterised by the "male bread winner model" are all ranked low in household disposable income. Income below the first quartile is lowest in countries with the lowest female employment rates. Thus, Spain, Italy, UK and Austria have a disposable income below $\$ 10,000$ in the first quartile.

In order to get a better description of the relative importance of pension income Figure 2 repeats the information given in Figure 1 but now only for households in the age bracket 65-90. Except for the United States, which had a high employment share after 65, income of households 65+ should mainly come from pensions. Again Finland, Sweden and Norway have a compact distribution, with the smallest difference between the lowest and the highest decile. The income dispersion is highest in the United States, Canada, Austria, Italy and Germany due to a very right skewed tail. According to Whitehouse (2003), these are all countries with a relative small maximum benefit from the public pension schemes. Thus private pension plans are more important and since these plans lack a ceiling a higher income distribution can be expected. While in countries like Sweden, Norway, Finland and Holland public pensions and transfers dominate and make the income distribution more equal.

Comparing pension and pension system across countries is complicated. However a recent OECD report, Whitehouse (2003), compares the values of pension

\footnotetext{
${ }^{4}$ It should be noted that this classification is not without problem and that there are country differences in definitions and categories, and also that the sample size is small for some countries.
} 
entitlements in nine OECD-countries. The paper includes both public and private pensions. An important distinction in this study is the difference between countries with a low or high ceiling in the pension system. Countries like Canada, Germany, Japan, the United Kingdom and the United States have ceilings for contributions and/or benefits in the mandatory system. Finland and the Netherlands have no ceilings, while Sweden and Italy have a high ceiling. At low level of earnings, the benefits are similar in all the countries, but at higher levels, benefits do not increase in countries with ceiling and increase if there is no ceiling. Countries with high ceilings provide income insurance through the mandatory retirement system. The replacement rate in those systems can be high even for high income earners. In countries with low ceilings the mandatory systems are focused more on redistribution, only ensuring that all pensioners meet a reasonable minimum income standard.

It is also important to remember the role played by the tax and benefits system. In most countries older people pay less income-tax compared to people of working age. Some treat pension income more favourably than earnings, and most do not levy social security contributions on older people. These policies mean that the tax burden of older people is lower than for people of working age. Whitehouse (2003) reports that at an average income the average tax burden (in the nine countries studied) is ten percentage points lower for pensioners than it is for workers. Therefore differences in taxes between pensioners and workers are an important means of governments to support people during their retirement. The so called net replacement rate - the value of pension benefits for a full-career worker relative to earnings when working, is a measure that captures this kind of compensation. Again according to Whitehouse, on average, one fifth of the net replacement rate for a worker on average earnings is due to tax differentials rather than the pension system.

\section{The Swedish experience}

\subsection{Changes in income 1975-2003}

In the period 1975-2003 mean disposable income per household, adjusted by an equivalence scale, on average increased by a modest 1.5 per cent annually in fixed prices. ${ }^{5}$ Figure 3 details these changes with the recession in the first half of the 1990s and the subsequent recovery. The discontinuity in the beginning of the 1990s is explained by changes in the definition of income concepts at the time of a major tax reform in 1991-92. Similar to many other countries the inequality of income has increased, in particular in the 1990s influenced by the boom in the stock market at the end of this period (Figure 4). We find for instance that elderly and married or cohabiting partners gained more in income than young and singles. Families with children also experienced a rather low growth in income.

Income and labour force participation for the baby-boom generation 1992-2003

In the sequel we will not focus on cross sectional distributions but rather on cohort differences. ${ }^{6}$ Because we are interested in the baby-boom generation we follow closely the economic status of those born in 1940 to 1949. Also, as a comparison, we consider two older cohorts (born in 1934 and 1937) as well as two younger cohorts (born in 1952 and 1955).

\footnotetext{
${ }^{5}$ The household concept "family unit" does not include adult children living with their parents. They are considered singles.

${ }^{6}$ The data used in this section comes from the Swedish register-based LINDA and consists of a large panel of individuals and their household members, from 1992 to 2003. All figures in this section are based on a balanced panel from LINDA.
} 
For most people income from market work is the most important income source. To study changes in labour force participation as people age and across generations are thus important in order to understand differences in income. Figures 5a and 5b show the labour force participation rates for men and women belonging to the birth cohorts mentioned. Participation is here defined as having income from employment or business.

In 1992 the cohort born in 1934 was 58 year old and those born in 1955 were 37. As expected these cohorts start out with a high participation rate, males with a rate close to 95 per cent and women with one close to 90 per cent. Due to the recession in 1992-1993 there was a decrease for all cohorts, but the long run effect was quite different across cohorts. The youngest cohorts recovered immediately, while the participation rates among men and women aged 52 and 58 in 1992 never recover but dropped monotonically down to almost 50 $\%$ for men and 40\% for women in 1999 (when they were 65 year old). There was an asymmetry in the effect of the recession, young workers returned to work after the recession while many of the older workers never returned. However, we should perhaps not overemphasize the effect of the 1992 recession on labour force participation. Even without a recession we should have seen a withdrawal from the labour market among these cohorts, in particular after the age of 60 . At the age of 64 , one year before the typical retirement age, the labour force participation rate was low: 55 per cent for men and only 42 per cent for women. These differences in labour force participation explain much of the income differences with increasing age as well as cohort differences in income.

Figures $6 \mathrm{a}$ and $6 \mathrm{~b}$ show the income from employment and business ${ }^{7}$ for both men and female respectively. These income estimates include all individuals regardless of working status. Compared to the corresponding graphs for labour force participation, these graphs illustrate once more how the 1992's recession influences labour incomes for the cohorts considered. There is decrease in mean income in 1992 but also a recovery for all cohorts except the oldest ones (cohorts '34,' 37 and '40). The drop for these old cohorts reflects the decrease in participation. We also observe that the youngest cohorts ('55,'52) recover faster compared to the middle ones ('49, '46, '43), especially for men.

In order to see the earnings profiles for those with an income from work Figures $7 \mathrm{a}$ and $7 \mathrm{~b}$ were drawn and based only on people with a nonzero income from employment and business. As expected the recovery trend is now more evident for all cohorts, including the oldest ones. Figure 7b shows an interesting trend for females born 1937, with an almost constant income from work from age 55 to age 62, followed by a sharp decrease. Compared to the two oldest cohorts, the 1940 cohort recovers faster but, also, much slower if compared to the youngest cohorts. These trends provide evidence of an increasing number of part time retirees among the oldest. This raises the interesting question of the long term effect of the crisis in the beginning of the nineties. Since many old age working individuals were offered attractive occupational pensions, they have chosen to retire early. Since we intend to forecast the income of the elderly this is important and it is also shows the importance in allowing for differences in outcome of an economic shocks across birth cohorts.

The same story could be told based instead on incomes from pensions. In figure $8 \mathrm{a}$ and $8 \mathrm{~b}$ all incomes from pension, public as well as private, are included. Again, we see an increase for all cohorts but much stronger for the oldest as a result of a significant decrease in the labour force participation. The increase in income from pension is starting with age 58-59 and continues through age 65 . Then we observe a relatively constant income because people start to collect old-age social security pension. This relatively sharp increase is due to the early exit from the labour force which was very common among the old cohorts (early retirement). It is usually the case that, during transition from work to retirement, people

\footnotetext{
${ }^{7}$ In reality it is almost entirely due to income from employment. We use year 2000 prices, as a base for income computations.
} 
collect benefits from the public sector such as disability pension or unemployment compensation, while only after 65 they start to claim old-age social security pension. This pattern is quite similar for both males and females.

Because income from capital is an important income source for at least some retirees we also analyze the cohort profiles of capital income, Figures 9a and 9b The level is much lower and the profiles much more erratic. The distribution of income from capital is highly skewed to the right and in fact the medium income for all cohorts and all year is zero. Still there is an increasing trend with increasing age, but it is to a large degree is explained by the increase in the price of shares. Both 1999 and 2000 represent a period of an unprecedented high level of the Stockholm Stock Exchange general index, see Figure 10.

However, the importance of the dramatic decrease thereafter should not be overemphasized. According to Statistical Sweden (2002) 67 \% of the total value of Swedish quoted shares was in 2000 owned by one percent of the population. Households for which shares represent both a substantial value as well as a substantial part of the portfolio are rather few. On the other hand the decreased return on financial wealth have a broader and more general effect on other asset, like pension savings, including PPM, mutual funds, etc. The unequal distribution of financial wealth explains why the boom and bust of the Stockholm Stock Exchange did not have a more dramatic effect on household incomes.

In order to finally arrive to an analysis of cohort changes in economic standard Figure 11 shows disposable income. We see similar patterns for all cohorts except the oldest ones. Disposable income starts to decrease around the age 57- 58 when workers start to withdraw from the labour market. The decline continues until age 64, one year before they start to collect old-age pension, then it starts to increase. However, after 65- 66 the disposable income declines again. It is interesting to notice that if we compare disposable income in the years prior to retirement (65) and in the years immediately after retirement we will get a very high replacement rate.

Section 6 provides a closer look at the replacement rates based on SESIM simulations. Since the simulation model SESIM was fundamental to the analysis, it will be presented first, with focus on the modelling of real and financial wealth as well as income. Then the new Swedish pension-system will be described briefly, followed by the design and the results of the simulations.

\section{The Swedish Micro simulation Model Sesim}

\subsection{Introducing SESIM}

In 1997 SESIM was developed as a tool to assess the Swedish education financing system. Part of that work has been documented in Ericson and Hussénius, (2000). We refer to this as version I of SESIM. Since year 2000 the focus has shifted from education to pensions. To evaluate the financial sustainability of the new Swedish pension system is a major purpose of SESIM. This new focus has also implied that SESIM has been developed into a general MSM that can be used for a broad set of analyses. This version is the second version of SESIM and this is documented in Flood et.al (2003). The present version, SESIM III, maintains the focus on pensions but extends the analyses to including health issues amongst elderly.

SESIM is a mainstream dynamic MSM in the sense that the variables (events) are updated in a sequence, and the space in time between the updating processes is a year. The start year is 1999 and every individual included in the initial sample $(\approx 100000)$ then goes through a large number of events, reflecting real life phenomena, like education, marriage, having children, 
working, retirement etc. Every year the individuals are assigned a status, reflecting their main occupation during the year. Every status is related to a source of income, working gives earnings, retirement's gives pensions etc. The tax and benefit systems are then applied and after tax income is calculated. If this simulation is repeated for a long time period life-cycle income for individuals can be generated.

The sequential structure in SESIM is presented in Figure 12. The first part consists of a sequence of demographic modules (mortality, adoption, migration, household formation and dissolution, disability pension, rehabilitation and regional mobility. After that comes a module for education (compulsory school, high School (Gymnasium), municipal adult education (Komvux) and university. Next module deals with the labor market including the retirement decision. The date of retirement can be decided according to a retirement model, but it is also possible to choose a specific age (it is also possible to allow for some variation around this age).

The labor market module also includes a model for sick leave, unemployment, employment and a model for imputation of labor market sector. The sector is required for calculations of occupational pensions. In SESIM, we have implemented the rules for occupational pensions as well as the choice of labor market sector. We also allow for change of sector and the occupational pension is then adjusted in accordance to the new rules for occupational pensions in that sector.

Having gone through the sequence this far, next step is to decide a status for each individual. There are nine different statuses, note each individual can only have one status each year (the status emigrated is an exception). These statuses reflect the main occupation during a year. Of course this is a simplification since an individual in reality can have many occupations during a year. You can be a student part of the year and work the other part etc, or you can have several occupations at the same time. The different statuses are given below.

1 child (0-15 years old)

2 old age pension: individuals with income from old age pension

3 student: individuals who study at gymnasium, adult education or university

4 disability pension: individuals with income from disability/sickness benefit

5 parental leave: women who give birth during the year

6 unemployed: individuals with income from unemployment insurance or from labor market training

7 miscellaneous

8 employed: market work

9 emigrated: individuals living abroad with Swedish pensions rights. Note, this classification is not unique since they also can have income from early retirement or old age retirement.

Given status next step is to generate an income. For status 8 (employed) the earnings equation is used to determine income. For other kind of status, e.g. unemployed different rules can be applied to obtain an income. After calculation of income, a module for wealth capital income and housing is entered. Since it is rather unusual to include formation of wealth in a MSM, we give a more detailed description below. After wealth/housing a large module describes all relevant tax, transfer and pension rules. For the old age pension system, the rules for public and occupational pension have been implemented in all relevant details. Given all information above the household disposable income can be defined. Next, a module for public consumption is entered; the details are discussed in Pettersson \& Pettersson (2003). The final 
module reflects the important update in SESIM III, the health module. In this module the need for care is imputed. In order to assess the importance of relatives as a resource we impute the geographical distance to relatives. The health status is calculated next and then days with inpatient care followed by severe disability and finally assistance for elderly is imputed.

\subsection{Modeling of real and financial wealth in SESIM}

In SESIM we have chosen to model financial wealth, savings in private pension annuities, the market value of owner occupied homes, wealth invested in other real estate, and debts. Financial wealth includes a number of different assets such as bank accounts, bonds, mutual funds, stocks and shares, and life insurances, but not private pension annuities. The latter asset is modelled separately for two reasons, first because this kind of savings is designated life-cycle savings with the purpose of complementing public and occupational pensions, and second because investments in this asset are deductible from income at income taxation. We thus need this deduction to compute the income tax. A further break down of financial wealth by risk level would have been of interest, but it had required a completely different set of models and we also would have to model -within or outside SESIM - the returns to each of these assets, a major task well outside our project.

Investments in real estate have been divided into two components, owner occupied homes and other real estate, because the major asset of many Swedish households is just their home. This component includes both one and two family houses as well as condominiums. In 2002 about 43 per cent of Swedish households owned a house and 14 per cent a condominium. ${ }^{8}$ Condominiums are most common in major cities. There are no direct data on market values of owner occupied houses and condominiums in the registers of Statistics Sweden, but they have been estimated using the product of the tax assessed value of each property and so called purchase coefficients. These coefficients are the annual mean ratios of the price to the tax assessed value of each sold unit in a relatively small area.

Comparisons with self-reported survey data show that these estimates give good mean levels. They might though underestimate the dispersion of house values a little. These estimated market values form the dependent variable in our model for market values, see below.

Other real estate is a mixture of different assets. One large component is secondary homes. About 13 per cent of Swedish households had a secondary home in 2002, some of which represented a major investment. Included in the aggregate Other real estate are also commercial apartment complexes, farm land and forests and other property owned by private households. There are rather few owners of these properties, but they represent large values for the owners. The corresponding distribution is thus strongly positively skewed.

Debts are modelled as a single category and it includes all kinds of debts such as mortgages on homes and other real estate, regular bank loans and consumer credit. It might have been of interest to separate these different types of debts, but such detailed information is not available in the register data of Statistics Sweden, and it is not obvious that a separation is analytically meaningful. A household can increase the mortgages on their house not only to invest more in the house but also, for instance, to buy a car, a boat or to go on a holiday trip. Thus, the legal form a loan takes does not necessarily say much about the uses of the borrowed money. Register data on mortgages and loans originate from banks and other credit institutes, which have to supply this information to the tax authorities for taxation purposes. Tax payers also have an interest to declare their loans because interest paid is deductible from incomes. Register data on mortgages and loans are thus considered being of good quality.

\footnotetext{
${ }^{8}$ These estimates are based on LINDA, using the family concept of this source.
} 
Figure 13 gives a view of the model structure and simulation path of the wealth model. The simulation starts with financial wealth. Different models are used depending on if the household had financial wealth or not in the previous year. Then follows the simulation of Other real wealth, again the choice of model depends on the household having Other real wealth or not in the previous year. In the third major step private pension wealth is simulated and in the fourth the value of any owner occupied home. Ownership might change if the household moves and decides to buy a (new) house after the move. SESIM thus simulates geographical mobility and tenure choice before the market value of a house is determined. Finally the debt of each household is updated and the cost of housing is simulated. The latter entity is of interest in its own right, but also needed for the computations of housing benefits. Modeling financial wealth

As mentioned there are two components of financial wealth: private pension annuities and other financial wealth. The latter component includes stocks and shares, bonds, mutual funds and bank accounts, and it will in the sequel for short be called just "financial wealth"9. In modeling financial wealth we have chosen to work with separate models for households which previously respectively had and did not have these kinds of assets. In the first case we use a dynamic panel model and in the second the combination of a logit model which simulates the transition from not having to having financial assets, and a regression model which simulates the amount. All three have been estimated using the Linda panel data. One might note that the period for which data are available, 1999-2003, is a period of exceptional changes in the stock market, which might have resulted in estimates that are not typical for other periods. Furthermore, our short panel does not allow any elaborated dynamic specification, nor is it possible to identify and estimate cohort effects separately from period effects.

The model for those who did not have any financial wealth previously is a so called two-part model. That is, the model for the probability to acquire financial wealth was estimated independently of the model that determines the amount of financial assets acquired. The reason for using the two-part model compared to, for instance, a generalized tobit model or a Heckit type of approach, is that we focus on obtaining good robust predictions rather than on explaining selectivity. Manning et. et al. (1987) showed that the two-part model performs at least at well as the tobit type 2 model. Flood \& Gråsjö (2001) demonstrated the sensitivity of the generalized tobit model to errors in the specification of the selection equation, which produce bias in all the estimated parameters.

Model specifications and estimates are exhibited in Table 2. For households that did not have any financial wealth the probability to acquire some increases with increasing age. This could be the result of increased financial saving in middle age when mortgages have been reduced and children have left home, and of decreased investments in own home and other real estate after retirement. The relative position in the income distribution also determines the probability to acquire financial assets, the higher incomes the higher probability. ${ }^{10}$

Although not uniformly and with the exception of the very old the amount acquired increases with increasing age. The differences due to age are though relatively small. Those who are in the top right tail of the income distribution acquire more financial wealth than most people, about 25 percent more than those who have incomes below the 90 th percentile.

\footnotetext{
${ }^{9}$ Financial assets abroad are included to the extent Swedish tax payers and tax authorities in other countries have reported them.

${ }^{10}$ We have here used a relative measure of income, i.e. the percentile of the income distribution, rather than income as such in order to avoid that a general increase in income level will drive the probability towards 1 as income increases over long periods. This is a general problem in simulation models such as SESIM.
} 
In the dynamic random effects model the estimated effect of the lagged stock of financial assets (Table 3) shows that there is a strong persistence in the investments of households. It is a little smaller among young people than among old, and among rich people compared to poor. The relative position in the income distribution has the expected effect, high income households invest more. Price changes in the stock market have a strong influence on the stock of assets held by households. Finally we might note that the variance of the purely random component is much larger than that of the unexplained household specific effects.

\section{Tax-deferred pension savings}

Because there are no register data on tax-deferred pension savings we first need estimates of theses stocks as of 1999, then a model which forwards these stocks after 1999. Because register data include information about how much each individual has paid into pension policies and claimed deduction from income each year, the simple idea is to construct accumulated savings by using Linda panels. Individual savings are summed up over years and the resulting stock is increased each year by applying the average return given by life insurance companies. In order to reduce the starting value problem, we started as early as 1980, at which time private tax-deferred pension savings were rather unusual.

Table 4 summarizes the main characteristics of pension savings during the period 1980-2000. Column (2) gives the share of all individuals with pension savings; note this is the share of the whole population, regardless of age. Thus, during this period there has been an increase from about 4 to $21 \%$. The share with a positive accumulated savings, i.e private pension wealth, is given in column (6). In year 2000, more than $30 \%$ have a positive accumulated savings, the mean value, column (7), is 110863 SEK and the corresponding mean of yearly savings, column (3), is 6591 SEK. Even if the share of pension savers has increased the yearly amounts have not. The yearly savings reached the highest value in 1989 and since then it has gone down. The reason for this is that changes in the tax rules after 1989 made deductions of savings from income less generous, and that the return on these savings has been quite low in more recent years.

The accumulated pension savings are given in column (8). The low value in 1980 indicates that the starting value problem is quite small. Pension savings were unusual before 1980. The total pension wealth has increased to some 315 billion SEK in year 2000. ${ }^{11}$ Given the accumulated stock of pension savings in 1999 we assume that whose who claimed deductions in 1999 continue to do so in the following years until the age of 64 by the same amount increased by the CPI. ${ }^{12}$ For those who did not save anything in 1999 and were in the age range 18-64 we applied a two-part model estimated from LINDA data (Table 6). The simulated amount saved in 2000 was then also applied to later years but increased by the CPI. For each year the probability of pension saving is simulated. If an individual is predicted to be a pension saver, the amount is also predicted. Again it is assumed that the individual continues to save this amount (adjusted by CPI) until he retires. Thus, for those individuals who do not save the probability of saving is simulated every year. Note, that the yearly amount saved is indexed by the CPI, but the stock of pension savings is increased by an interest rate for long term bonds.

\footnotetext{
${ }^{11}$ Compared to a few survey estimates from the Swedish Household Panel Survey (HUS) these estimates compare relatively well, see Klevmarken (2006)

${ }^{12}$ Of course this assumption has been introduced as a simplification, but there is some support for it in the data. Comparing the decile mobility for individuals with pension savings in 1995 with the same individuals in 2003, shows that the majority stays in the same decile or move up or down one decile.
} 
The estimates in Table 5 show that the probability to invest in private pension policies has a reversed U-shaped relation with age. It peaks at about 30 years of age and stops just before the typical pension age of 65 . The estimates also show that the higher education and the higher income the higher probability to invest, and that immigrant have a smaller probability to invest than Swedes. The amount invested increases with increasing age. The relation is close to linear. Females have a higher probability to invest than males but if they invest the amount is smaller than that invested by males. Schooling and income also determine the amount invested in the expected direction. The higher education and incomes the more invested. Among those who invest Swedes do not invest significantly more than immigrants.

\section{Household real wealth}

Household real wealth is decomposed into two components; Own home and other real wealth. Since the probability of owning a home is modelled in the regional mobility module only the model that determines the market value of a home and the model that simulates other real wealth is discussed here.

The market value of a home is primarily determined by its location, size and qualities. Changes in values depend on factors that influence demand and supply, such as changes in income and wealth and in the cost of borrowing. We do not try to formulate and estimate a model of the market value in this sense. We need a model which predicts the market value of the home of a particular family. In addition to some of the variables mentioned we will thus also use properties of the family as predictors.

The estimation of the market value model for own homes is based on both Linda and HEK data. Since information about house area is missing in Linda, HEK data from 1999 have been used to estimate a model of floor area (area in $\mathrm{m}^{2} / 100$ ) in order to impute this variable. The results are not reported here but the most important findings are that the age of the owner matters and that the size reaches a maximum in the age bracket 45-49. Marital status and number of children have strong effects. Income also has a strong effect. Those who belong to the first quartile have a house area $46 \mathrm{~m}^{2}$ smaller than those in the highest income quartile. There is a large negative Stockholm effect, dwellings are $12 \mathrm{~m}^{2}$ smaller compared to areas outside Stockholm, Gothenburg and Malmö for otherwise comparable houses and families.

Using the imputed value of floor area, jointly with the other covariates reported in Table 6, a model was estimated on data from 1999. The sample was limited to house owners and owners of condominiums having a property value between $50 \mathrm{tkr}$ and $10 \mathrm{mkr}$. There is a clear age effect and again an inverted-U relation, the maximum value is about 1.1 mkr for households in their mid forties to mid fifties. There are strong and significant effects of marital status, region, house area, financial wealth and nationality. The market value of a house in the Stockholm region is $\left(\mathrm{e}^{0.88}-1\right) 100=141 \%$ higher than a house in the reference region (rural region). The market value for a household with a financial wealth below the median is $42 \%$ of the value for a household in the highest wealth group.

The mixture of large and rather small properties in the aggregate Other real wealth makes it difficult to estimate good models. The distribution is heavily skewed. In the simulations we distinguish between households that have this asset and those who do not have it. In the first case we use a simple random walk. In the second case a logit model was estimated for the probability to buy property in the next year and a robust regression to simulate the amount. 
The estimates of Table 7 show that the probability to invest in other properties reaches a peak at middle age. Couples have a higher probability to invest than singles and there is a rather strong income effect. High income people have a much higher probability to invest than low income people. Income also determines the amount invested.

\section{Models of debts}

In SESIM we distinguish between study debts and other debts. Other debts include all debts but the study loans college and university students are offered by the government. It is assumed that the take up rate is 100 per cent and that students borrow as much as they are allowed to. Study debts are increased by an interest rate determined by the government. Repayments of principal and accumulated interest are proportional to the taxable income of the borrower according to certain rules, which are followed in SESIM. The reminder of this section deals with other debts than study loans.

Assuming that most households do not decrease or increase their debts much from one year to another, we need models that simulate debts at the end of next year conditional on current debts. We also need to account for any major investment a household might do in the coming year that might influence their decisions to take up new loans, such as buying a new home.

The analysis of the distribution of debts and the dynamics of debts was limited to stable households in the period 1999-2002. New households that have been formed through marriages, separations and deaths will have their assets updated by adding the wealth of new household members, by following standard rules for bequests and in the case of separation by dividing the assets between the newly formed households using common rules. Within stable households 77 per cent have debts. The median debt in this period was 156000 SEK while the mean debt was 355000 SEK. The distribution is thus positively skewed. The largest registered debt was 176 millions SEK.

A few households show major changes in debts in a year. The largest observed increase was 77 millions and the largest decrease was 97 millions. The changes observed for the majority of the households are, however, much smaller. The mean change was an increase of 13600 and the median change was 0 . Of those who had no debt in a year 11 per cent had one the following year. Of those who had a debt in a year about 92 per cent also had one the following year.

The purchase of a house or other property is usually partly financed by a mortgage or loan. One might thus expect that households that buy or sell property would increase and decrease their debts respectively unless they owned property before or bought new property after having sold their old property. Data show that households that had no real estate or real estate at a value of less than 10000 SEK in a year but owned more than 10000 SEK worth of real estate in the following year in the mean increase their debts by 450000 SEK while the median change was a decrease of 6000 !

A similar pattern emerges if one selects out households that owned real estate at a value of at least 10000 in year, but had no such assets or at least less than a value of 10000 in the following year. This group of households decreased their mean debts by 669000 while the median decrease was only 15000 . There were, however, also households that increased their debts with large amounts.

We do find that changes in real estate investments influence the amount of debt a household has, but also that there is much heterogeneity in behaviour suggesting that other factors than investments in real estate might sometimes have a dominating influence on the decisions to take up loans. 
Lets first consider the group of households with no debts at the end of a given year t-1. We have first estimated a random effects probit model for the event of having debt at the end of the following year t. Explanatory variables were: the age of the oldest household member, if single, the change in real estate investments and in financial assets, the change in the sum of taxable income from work for all household members and last years disposable income. The current value of disposable income cannot be used in this equation because it will become simulated after the debt variables in SESIM. For this reason taxable income from work had to be used. ${ }^{13}$ The cost of borrowing is captured by a real rate of interest on short assets. Table 8 gives the estimates.

The probability to go into debt decreases with increasing age. Singles have a smaller probability to take up loans than couples, while those who have increased their investments in real estate during the year have a higher probability. If financial assets have increased since last year the probability to take a loan is smaller, but this effect is relatively weak. The higher income the easier the household has to pay interest and reduce the principle, and thus also easier to get into debt.

The model estimated to simulate the size of any loan is a random effect panel data model. The observations were conditioned to households with no debt in the previous year. The explanatory variables were the same as in the probit equation except for the variable change in taxable income from work, which was dropped, and the change in the real rate of interest, which was added. The results are displayed in Table 9.

The results show that not only does the probability to take up a loan decrease with increasing age but so does the size of the loan taken. Singles borrow less than couples. The larger increase in real estate investments the larger will be loan become, and the higher disposable income the larger loan can the household afford. The real rate of interest influences the size of the loan strongly, the higher rate the smaller loan. We might finally note that unmeasured heterogeneity among the households amount to a little more than 30 per cent of the total residual variation. The properties of the estimated residuals $u$ and e suggest that a normal approximation is not too bad. It implies that normal random numbers can be drawn when the amount of debt is simulated.

Let's now turn to the larger group of households who already are in debt and analyze how their debt changes. Also in this case a two-part model was estimated. The results from a random effects probit model for the probability to stay in debt can be found in Table 10 and the results from the random effects regression model for the amount borrowed in Table 11.

The probability to stay in debt decreases with increasing age independently of the size of the debt. Independently of age the probability to remain in debt increases with increasing debt. This relation is almost the same through the whole age range, possibly with a somewhat smaller factor of proportionality above the age of 75 . Singles have a smaller probability to stay in debt than couples, and households that have increased their investments in real estate have a higher probability. The effect of changes in the stock of financial assets is negligible. A high disposable income decreases the probability somewhat, but this effect is small. The cost of borrowing is important though, the higher cost the smaller probability to stay in debt.

It was not easy to find a satisfactory model for the size of the debt given that the household remained in debt. We have finally selected a random effects regression model that was estimated using a sample constrained to households with a lagged debt exceeding 10000 SEK. Without this constraint, i e using all observations with a debt, the right tail of the distribution of the residuals became very thick. In the simulations this resulted in a few

\footnotetext{
${ }^{13}$ I $\mathrm{f}$ we had been able to use the change in disposble income the estimates could have been interpreted in the following way: $\mathrm{bx}_{\mathrm{t}-1}+\mathrm{c}\left(\mathrm{x}_{\mathrm{t}}-\mathrm{x}_{\mathrm{t}-1}\right)=(\mathrm{b}-\mathrm{c}) \mathrm{x}_{\mathrm{t}-1}+\mathrm{cx}_{\mathrm{t}}$
} 
households having excessively large debts. Although the sample was restricted to households with at least 10000 in debts, the model will in SESIM be applied to all households with a debt. ${ }^{14}$ The parameter estimates are displayed in Table 11.

Lagged debt is an important variable explaining current debt. The more indebted a household is the more will it reduce its debts. The estimates imply elasticities that vary from -0.2 among the youngest households to -0.04 among the oldest. So young people with high debts tend to decrease their debts more than elderly with high debts do, but independently of the size of the debt elderly generally reduce their debts more. Households which have increased their investments in real estate accumulate more debts than other households do, and the higher income a household has the more debts will it get. The cost of borrowing does not only influence the probability to stay in debt but also the size of the debt. The higher cost the less borrowed.

Examination of the residuals, both the household unique component $u$ and the general residual e, shows that both distributions are negatively skewed and have a rather high kurtosis. It is thus not advisable to simulate using random draws from normal distributions. Instead we have drawn random numbers from the empirical distributions.

\subsection{Income generation in SESIM}

\section{Income from earnings}

Due to the importance of earnings a detailed description of this process is provided. It is well known that using information from a cross section only, in general produce incorrect predictions of individual earning profiles. As a consequence it also produces incorrect predictions for a given cohort. For this reasons the estimated earnings model in SESIM is a random parameter model estimated on panel data, i.e. the same individual is observed repeatedly in the data. The model is given as:

$Y_{i t}=\mathbf{X}_{i t} \boldsymbol{\beta}+\gamma_{i}+\varepsilon_{i t}$, where $\gamma_{i} \sim N\left(0, \tau^{2}\right)$ and $\varepsilon_{i t} \sim N\left(0, \sigma^{2}\right)$.

The error components $\gamma_{i}$ and $\varepsilon_{i t}$ are assumed to be independent. The random intercept $\gamma_{i}$ is designed to represent unobserved heterogeneity (typically interpreted as ability). The implication is that earnings for a given individual are not independent over time, but independent across individuals. ${ }^{15}$

The earnings equation is estimated on a four year panel and includes in the Xvector variables such as; experience, highest level of education, marital status and nationality. Separate models are estimated for occupational sector as well as for gender. The dependent variable is the logarithm of earnings.

Table 12 shows the estimated parameters. As expected, earnings increase at a decreasing rate in experience. Except for self-employed, women have a lower return on experience as well as a flatter experience-earning profile. There is an educational premium in all sectors and the largest return on a university degree (compared to compulsory level) is for the males in the state governmental sector and for the self employed females. On the other hand the lowest return is for self employed males and women in the private blue collar sector. Nationality and marital status have only minor effects, the exceptions being that Swedish born males, self employed or in the state governmental sector, have higher earnings.

\footnotetext{
${ }^{14}$ The restriction of the sample reduced its size by about 5 per cent.

${ }^{15}$ For a presentation of statistical models for panel data see for example Baltagi (2001).
} 
The simulations of the earnings equation is based on the individual attributes in $\mathrm{X}_{\mathrm{it}}$, the estimated parameters $\hat{\boldsymbol{\beta}}$ and the random numbers $\tilde{\gamma}_{i}$ and $\tilde{\varepsilon}_{i j}$. The random numbers are drawn from two independent normal distributions with variance $\hat{\tau}^{2}$ and $\hat{\sigma}^{2}$ respectively. The simulated earnings are calculated as $\tilde{Y}_{i t}=\mathbf{X}_{i t} \hat{\boldsymbol{\beta}}+\tilde{\gamma}_{i}+\tilde{\varepsilon}_{i t}$. Since $\tilde{\gamma}_{i}$ is specific for each individual and constant over time, only one draw at the start of the simulation is need, but draws for $\tilde{\varepsilon}_{i t}$ have to be repeated for each year (and new individual). As follows from Table 2, the individual variation, $\hat{\tau}^{2}$, is larger than the random component, $\hat{\sigma}^{2}$, in all sectors. However there is a large cross-sector difference in these estimates. The self employed have the largest individual variation, indicating the large heterogeneity in this sector. Self employed covers everything from low skilled low paid job to highly paid consultants. The lowest individual variation is for blue collar males and for females in the local governmental sector.

Note, that the model described only generates income from market work, i.e. for individuals with status= market work. For other individuals incomes are generated conditional on their status.

\section{Pension income and other benefits}

Social security pensions are computed using the rules that apply each year jointly with simulated income histories and eligibility status. Each worker is simulated to belong to one of the four major contract areas and will then receive occupational pensions accordingly following the rules of each contract.

How the stock of private pension annuities has been estimated is explained above. Regarding the income generated from these stocks many different options are possible, a limited time, the whole lifetime etc. In all the simulations reported here a five year period after retirement has been used. Benefits other than pensions such as housing allowances, child allowances and social relief are computed using the rules of the benefit systems.

\section{Income from capital}

The structure of the set of models specified to simulate incomes from capital is partly determined by the income tax legislation. Incomes from capital in the form of interest, dividends and capital gains are taxed by a flat rate tax of 30 per cent. The tax base is net of interest paid and capital losses according to certain rules. The tax on capital gains on own home can under certain conditions be postponed if a new replacement home is acquired.

SESIM now includes one model that simulates interest and dividend incomes, a set of rules that determines the capital gain on an own home and any postponement of taxation, a model that simulates the capital gains from other assets and finally one that simulates interest paid on debts.

Interest and dividend incomes

It is natural to model interest and dividend incomes as a rate of return on financial assets. In order to do this the mean of the assets at the end of 1999 and 2000 was computed for every household in our LINDA sample and related to the sum of all interest and dividends earned in 2000. The first quartile of the mean asset variable was just 3121 SEK and most households in the first quartile had no financial assets at all. To avoid excessively high return rate estimates all households with less than 1000 SEK were dropped from the sample. As a result 22 per cent was dropped and of these only 2 per cent had any interest or dividend incomes and they were small. The mean was only 889 SEK. The quartiles of the resulting distribution of the rates of return were $0.6,1.1$ and 1.7 per cent respectively. There were, however, a few 
unrealistically high values, most likely caused by too small mean asset estimates. It is possible that a few households owned an asset part of the year and collected a return, while their financial assets were small both in the beginning and in the end of the year. For this reason we truncated the right tail of the rate of return distribution at 5 per cent and thus dropped another 4 per cent of the sample. The resulting distribution is censored from the left because between five and ten per cent of the households had no return on their financial assets. A tobit model was estimated using schooling, age, a dummy variable for marital status and the mean value of the assets as explanatory variables. The results are found in Table 13.

Interpreting these results we find that the less schooling the smaller return. Schooling does not only increase the return in the labour market but also in the financial markets. There is a clear relation with age. People in middle age have a higher return than both young and old. One explanation is that they have a higher share of shares and stocks in their portfolios compared to those who are younger and older. Couples on average get a higher return than singles. The relation with the amount of assets owned is reversed U-shaped. Wealthy people have more investment opportunities and find it easier to get a good return. They might also be in a better position to diversify than less wealthy. Why the very wealthy earn relatively less is more difficult to explain.

Although the interpretation of the model parameter estimates is interesting the model explains relatively little of the variability in returns. Most of the simulation variability will come from the residual that has a rather large variance. For this reason we found that we could as well simulate the rate of return by drawing randomly from the empirical distribution, the deciles of which are displayed in Table 14. In the simulations we have interpolated linearly between the percentiles and also imposed a maximum of 0.3 . This distribution applies to the year 2000. If the average return in the financial markets changes cyclically or trend wise these estimates have to change accordingly. When simulating we thus multiply the rate of return drawn from this distribution by the ratio of a market rate for the current year and the year 2000.

\section{Capital gains on own home}

In SESIM we simulate both purchases and sales of owner occupied homes and record the price at which a transaction takes place (see section 4.2). The difference between the sales price and the purchase price of a given property is the capital gain, 80 per cent of which is added to the taxable income of capital ${ }^{16}$. If there is more than one owner of the property the capital gain is divided according to the shares owned. If a household sells their home and then buys another one within one year, and the gain exceeds a threshold, adding 80 per cent of the capital gain to the taxable income of capital is partly or completely deferred. If the new house is more expensive than the old the whole amount is deferred, if it is less expensive a share of the amount is deferred equal to the ratio of the market value of the new house to that of the old. This procedure is repeated for every new sale and purchase until the owner moves to a rented home or dies. In this way it is in principle possible to defer the tax on the capital gains of own homes until the owners die. Then the survivors have to pay the tax out of the deceased's estate. For each home owner who has previously sold a house or an apartment and used the opportunity to defer tax there is a cumulated deferred capital gain registered with the tax authorities. SESIM also keeps track of these amounts and applies the rules of deferred taxation. ${ }^{17}$

\footnotetext{
16 This applies symmetrically to losses.

${ }^{17}$ There is one simplification. If sales and purchases are not done in the same year then the household is assumed to move to a rented home and no deferral is allowed. In SESIM we thus do not strictly apply the one year rule.
} 
Capital gains from other assets than own home

Capital gains taxation also applies to gains from other properties and from financial assets. Register data only include information about total capital gains (losses) and it is not possible to distinguish gains by source. This makes it difficult to estimate a model for the gains accruing from other assets than own home. Register data, however, include information about the tax assessed value and an estimated market value of own homes. We used these data to eliminate from the sample all households that had reduced their investments in own homes in order to get a cleaner sample of households with capital gains from other sources. A potential source of error is the fact that we cannot eliminate those who sold their property and bought a replacement at the same or a higher market value. But this group is likely to defer the taxation of their capital gains from their old home, and the corresponding amount will not be included in the reported capital gain figure.

The distribution of net capital gains (the sum of gains and losses) is rather strange. The center of the distribution is essentially zero while there is a left tail with large negative values and a right tail with even larger (positive) values. The distribution thus has a high kurtosis and is positively skewed. The median is 0 and the mean 28467 SEK. It became difficult to find a model that could reproduce this distribution. Instead we have opted in favour of separate models for capital gains and losses. We first estimated a probit for the probability of having a nonzero gain, then a probit for having a loss conditional on no gain and finally a model explaining the size of the gain (loss) if the household had one.

Table 15 exhibits the estimates for the first probit model. Expect for age and marital status we use changes in the investments in property and financial assets, and gross wealth to explain the probability to have a capital gain. The change variables take the form of dummy variables, one for each quartile of the distribution of the change variable. For instance, the first of these dummy variables in Table 15 takes the value one if the household belongs to the first quartile of the distribution of decreases in real estate investments. The default is no decrease. Households which have decreased their assets are expected to have capital gains with a higher probability than households that have not changed or increased their assets and the more they have decreased their assets the higher probability they should have for a capital gain. The estimates of Table 15 confirm to this pattern. Sales of financial assets give a capital gain with a higher probability than sales of real estate. The effect of an increase in assets on capital gains is not as obvious. We only observe the net change that could hide a combination of sales and purchases. Because increases in net holdings result in capital gains, according to the estimates of Table 15, most investors must have sold and reinvested. The estimate for the last variable, gross wealth, suggests that large players have a higher probability of making a capital gain. The probability to make a gain is also higher for young people than for old and for couples compared to singles (Table 16).

The results for the probit to have a realized capital loss given that the household had no realized gains are rather similar to the previous results. The probability that young people will make a loss given that they made no gain is higher than the probability of a loss for old people. Couples have a higher probability than singles. Households that have no gains but have still reduced their investments in property have a higher probability to realize a loss than households which have a net increase in property investments. A net reduction of ones financial investments also give a higher probability to loose than a net increase, but the difference is only marginal. People who have high transactions without having gained have a relatively high probability of loosing. If wealthy people do not gain they have a higher probability of loosing.

The robust regression of the size of the capital gain on the same explanatory variables (Table 17), given that the household had a realized gain, shows that old people make somewhat larger gains than young people and that couples on average have somewhat larger 
gains than singles. The change in investment variables show that it is the size of the transaction that matters more than if the household makes a net investment or disinvestment. This is in particular clear for changes in financial holdings. Large increases or decreases in holdings result in large gains while small changes only give small gains. As one might expect wealthy households gain more than less wealthy.

We were not very successful in formulating and estimating a model for the size of capital losses. Instead we have chosen to draw randomly from the empirical distribution of the variable as such, the deciles of which are displayed in Table 18. Random draws are obtained from a distribution with linear interpolation between percentiles. Capital gains and losses are indexed by the CPI to capture changes in the general price level.

Interest paid and deducted

Almost 25 per cent of all households had deductions for interest paid on mortgages and loans. The median deduction was just above 14000 SEK, while the mean was close to 26000 SEK. The distribution is positively skewed and the largest deductions amount to a few millions.

It might be natural to relate the interest deducted to the total debt and simulate the corresponding rate. The problem with this approach is that about 25 per cent of all households have deducted interest although they did not have any debt at the end of the same year and about 10 per cent of all households have deductions without having any debt neither in the beginning of the year or in the end. It is of course possible to pay interest on a debt that was repaid before the end of the year, and it is also possible to take a loan after the beginning of a year and repay it before the end and still have interest to pay. Similarly we find households in the data set with large deductions but rather small debts.

In spite of these difficulties the advantages of modelling a rate rather than an amount are so great that we preferred this approach even if we will not be able to simulate a positive amount for households with no debt at the end of a year. The interest rate on debts was defined as the ratio of the interest paid by the household to the sum of all debts at the end of the year if this sum exceeded 1000 SEK. This truncation floor was used to avoid excessively high rates. Households with a debt less than 1000 but still had paid interest were dropped from the sample. With this definition 83 per cent of all households had a positive rate. The median was 5.6 per cent and the mean 7.8 per cent. The $95^{\text {th }}$ percentile was 14.1 per cent an there were a few observations exceeding 1.

The sample was split into two groups, one that did not pay any interest in the previous year and one that did pay. For each group a two phase model was estimated: a random effects probit model for the probability to have paid interest and a model for the amount. Note that in the probit models the alternative to paying interest is to have no debt or to have a debt but still not pay interest (in the current year).

The estimates of the probit models are given in tables 19 and 20. The probability to start to pay interest on debts is highest among young people, while the probability to continue to pay is highest among middle aged. People with secondary schooling have higher probability than people with less or more schooling. Couples have a lower probability to continue paying interest than singles, while this variable has no significant effect on the behaviour of those who start to pay interest. The higher debt ratio is the higher probability, while those who have higher debts than gross assets have a relatively lower probability to pay interest. One possible explanation is that they have borrowed from parents and relatives and do not have to pay interest or postpone any payments on these loans. The more real assets the household owns the higher is their probability to pay interest. The amount of financial assets owned only bites for those who already pay interest and the effect is negative. This variable probably captures those households that do not need to borrow because they have financial 
assets. The estimates for the income variable shows that the probability to pay interest increases with increasing income. People with good incomes can afford to pay interest.

The estimates of the regression models explaining the amount of interest paid conditional on paying can be found in tables 21 and 22. In both cases the dependent variable is the log of the interest rate paid in order to pull in the right tail of the distribution and avoid simulating negative rates. The number of panel observations is too small to estimate a panel model for the group that did not pay interest in the previous year, so in this case a simple OLS regression was used (Table 21). For the other group of households we used a random effects GLS regression (Table 22).

Of those who take up a loan and start to pay interest old people pay higher rates than young, probably because they have smaller incomes and perhaps less to offer in collateral. The less schooling the higher rates people tend to pay. The relation with age is less clear for those who already pay interest and the schooling variables came out insignificant. The higher debt ratio the smaller interest rate which might appear counter intuitive, but most households with high debt ratios probably have high mortgages on their homes, and interest rates on mortgages are usually lower than the rates on consumer credits and other loans. Support for this interpretation is found in the negative estimate for the amount invested in property for those who already had debts. The corresponding estimate for those who take up new debt is insignificantly different form zero. For this group we also find that the larger financial assets owned the less in interest they pay. The dummy variable indicating that debts exceed gross assets has no effect on the interest paid by new payers; they would probably never get a loan, while it has a counter intuitively negative effect for those who already pay.

\section{The Swedish pension system}

As mentioned earlier, pressure from an aging Swedish population forced the introduction of a new public pension-system in 1999, consisting of two parts: a notional defined contribution pay-as-you-go (NDC PAYG) and an advance-funded defined-contribution (DC). The former defined-benefit (DB) system is gradually being phased out, so the new system covers individuals born from 1938 to 1953 only partly, while covering individuals born thereafter totally. In the new pension system, employers and employees pay a total contribution of $18.5 \%$ on earnings: $16 \%$ to the NDC PAYG system and $2.5 \%$ to the DC system. Both systems are autonomous from the state budget and self-financing. However, general revenues from the state budget finance a minimum guarantee benefit for low-income earners and for lifetime poor.

\subsection{The Notional Defined Contribution Pay-as-you-go System}

The notional defined contribution pay-as-you-go system has the characteristics of a defined contribution system, but in a pay-as-you-go setting. One such feature is the full link between contributions and benefits, i.e., benefits are projected from contributions paid on all earnings during a lifetime. However, contributions are only recorded in individual accounts and the real contributions are financing payments to today's pensioners, as in any pay-as-you-go setting. However, contributions paid on annual earnings above a ceiling of about SEK 290,000 in 2003 (7.5 Basic Amounts (BA) $)^{18}$ per year do not qualify for pension rights. Contributions on the individual account represent a promise of future pension and are indexed

\footnotetext{
${ }^{18}$ The Basic Amount is calculated based on changes in the general price level, this is specified by changes in the Consumer Price Index and is set for a full calendar year.
} 
by average wage growth. Pension holdings and pension payments are indexed at a slower rate than average wage growth when average wage growth increases faster than wage sum and/or when observed average length of life increases after retirement.

A second feature of the NDC PAYG system is that the annual benefit level is calculated by dividing the total contributions in the individual account by age-specific and unisex life expectancy, which also includes an expected real rate of return of $1.6 \%$ per year.

\subsection{The Advance-funded Defined-Contribution (AF-DC) System}

The launch of the new defined contribution system in the fall of 2000 entitled the Swedish workforce, more than 4.4 million individuals, to invest pension assets in mutual funds. At this time, accumulated contributions from 1995 to 1998 were invested, which approximately corresponded to SEK 56 billion. The individuals could choose to invest in one to five different mutual funds from 460 available funds in the system. This means that the Swedish system has greater latitude for choice than U.S. 401(k) plans, which typically include only a few funds. For individuals who do not make an active investment decision, the government provides a publicly managed mutual fund.

Continuing annual contributions to the financial account system in the public and mandatory DC system are paid to an individual account once a year. These contributions are invested in mutual funds based on individuals' investment decisions. This implies that pension assets will grow at the rate of return of the chosen funds and based on annual contributions.

The accumulated capital in the individual account cannot be withdrawn until retirement age, which is flexible from the age of 61 . The annuity is calculated by dividing the individual account value by unisex and age-specific life expectancy at retirement day. During the years of retirement, individuals can choose a fixed or a flexible annuity rate: fixed, by moving the assets to the state annuity provider which includes a minimum annual return of 3 $\%$; flexible, by keeping the assets in the fund reflecting the market rate of return.

\subsection{Occupational Pensions}

Most employed individuals are also covered by central agreements between labor unions and employer confederations which include occupational pensions financed through employercontributions, both in addition to public pensions and covering incomes above the ceiling. Thus, these schemes are mostly important for high-income earners. In principle four occupational plans are distinguished: blue-collar workers in the private sector, white-collar workers in the private sector, central government employees and local government employees.

SESIM includes a model predicting which sector an individual works in, imputed upon entry to the labor-market. SESIM also allows for a change of sector, upon which accumulated occupational pension-rights are transferred to the new sector.

The four occupational systems have recently been reformed, in general, like the public system, from defined benefit to defined contribution. SESIM, we have implements both old and new rules in detail.

For blue-collar workers, in the private sector, the new system is a fully funded pension scheme where $3.5 \%$ of gross earnings are paid into a personal account in a pension fund. Each worker can chose about a dozen insurance companies to manage his pension fund. White-collar worker in the private sector are covered by a benefit defined scheme as well as a fully funded. The defined benefit scheme is determined by earnings the year before he retires. The benefits are $10 \%$ of that years's salary up to 7.5 BA, 65\% between 7.5 and 20 BAs, and 
$32.5 \%$ between 20 and 30 BAs. Contributions to the defined benefit scheme have been around 4.5 percent of gross earnings. The contribution to the fully funded system is approximately 2 percent of earnings up to $30 \mathrm{BA}$. The worker is free to choose a company to manage his fund. The fully funded system is normally claimed as monthly payments over a five-year period after retirement. After 1992, there exist two schemes for Central Government employees, one fully funded and one pay-as-you-go. In the fully funded $1.7 \%$ of annual salary is paid to a pension fund. The PAYSG is determined by average earnings during the five years preceding retirement. The benefits are the same as for White-collar worker but based on the five years average earnings instead of last years. The pension is reduced proportionally if the requirement of 30 years of contributions since age 28 is not met. The new system for local government employees is fully funded and similar to blue-collar workers.

\section{Retirement replacement rates}

\subsection{Concepts and measures}

One of the most common indicators used in pension policy analysis is the replacement rate. It provides information regarding the well-being during retirement years relative to the wellbeing during working years. The concepts and measures used to define replacement rates are subject to a great deal of controversy. The most direct approach would be to compare the retiree consumption while working with consumption after retirement. However high quality consumption data it is rarely available, therefore economists have concentrated mainly on the economic well-being measured by income data. Thus, it is the pre retirement and post retirement income that are usually compared - "... a ratio of some measure of post-retirement income to some, not necessarily similar, measure of pre-retirement income” (Boskin \& Shoven, 1984).

In order to carry out the objective of maintaining roughly the same standard of living through the working period and the retirement period, financial planners tend to argue in favour of 0.7-0.8 income replacement rates related to your own pre-retirement income. They attribute these figures below one to a supposedly lower cost of living during retirement. Furthermore, this also relates to the big controversy in the literature about retirees' consumption - the "retirement consumption puzzle." Most of researchers argue in the favour of decreasing consumption during retirement which is inconsistent with the life-cycle consumption smoothing hypothesis (Hurd \& Rohwedder2003). The retired have no longer job related expenses such as commuting costs; usually, by that time they would have paid their home mortgage and they do not spend money on raising children. The taxes for the retirees are typically lower and many advantages from price discounts are usually available and of course they are no longer saving for retirement. Also, since more leisure time is available, they could provide themselves with some services as cooking and home cleaning for which they might have paid while working. In the same time, once getting older, health related expenditures rise substantially, accounting for a big share of the retiree's income.

Apart from comparing income after and before retirement one should also consider pensions in relation to economy-wide earnings, that is pensions in relation to the income of the active population. This is a measure of the social adequacy of the pension benefits discussed in a recent OECD report (OECD, 2005), this is especially important for the low income pensioners, since they are less likely to have private pension savings or other assets.

To measure a replacement rates involve the choice of the most appropriate benchmark for the pre and post-retirement income. For the pre-retirement income there are 
typically two main approaches. One is to consider part of the earnings of one's career earnings in the last year prior to retirement, the average earnings in the last 5 years prior to retirement; or to include the peak earnings, as the average of the highest 3 or 5 years out of the last 10 years prior to retirement, the income at age 55 (Smith 2003), and so forth. The alternative approach is to consider in the denominator the average earnings during working years (22-64) (Boskin\&Shoven1987). On the other hand, there are researchers that argue in favour of replacement rates linked to the entire path of earnings during working years. Their argument is that individuals' entire life time working wages should be reflected in retirement income, not just the peak years. Secondly, it may be the case that during the last years before retirement some individuals are forced to career breaks, some part time work or not to work at all due to sickness or other problems independent of their choice, which would cause a substantially decrease in their earnings. The sensitivity analysis in section 6.3 illustrates the effects of the different individual pre retirement income on the replacement rate.

In order to carry out the goal of maintaining the same standard of living through the retirement period as during the working years, we believe that it is important to use a measure that could comprise the earnings towards the end of individuals' career. Therefore, it is reasonable to look at last 5 or 10 years prior to retirement period, when people usually form their expectations about retirement. If we should consider the average of this 10 year period, the average of the highest income of 3 or 5 years during this period or just one specific age (as 55 ) is a matter of debate and the purpose of the sensitivity analyses is to evaluate the effects of these choices.

Another important aspect is the variation of the retiree needs and expectations during the retirement period. Steurle \& Spiro (2000) found that relative replacement rates drop dramatically during retirement, concluding that in US, social security fails to give support to their retirees at the moment when they most need it, namely once they grow very old (>80 years).

During retirement, pensioners encounter two major sources of uncertainty: unexpected inflation and uncertain lifespan. If we take, for example, price index benefits that could permit retirees to keep their purchasing power during the retirement period it still does not necessarily adjust for the possibility of increased needs (especially related to health). While the price indexed benefits accounts for the imminent changes in the cost of living, the wage indexed benefits accounts for the changes in the standard of living, increasing demand of goods and services. In order to better protect against the erosion of the retirement income the pension benefits should be wage-indexed or both price and wage-indexed to account thus for both past inflation and real wage growth (Butrica et al. 2003). The design of the indexation in the Swedish system will be discussed further below.

\subsection{Replacement rates for the baby boomers}

SESIM is used to simulate incomes for a number of birth cohorts in the period 1999-2041. the pensions of these cohorts come both from the old and the new pension system. The transition from the old to the new system occurs gradually. The cohorts included in our analysis are those born in 1937 (completely in the old system), 1940 (6/20 in the new system), 1943 (9/20 in the new system), 1946 (12/20 in the new system), 1949 (15/20 in the new system), 1952 (18/20 in the new system) and 1955 (completely in the new system). The main indices of wealth and growth and their assumed average annual growth are presented in Table 23.

Table 24 shows replacement rates by birth cohort based on household disposable incomes (divided by the number of household members). These replacement rates have been computed for individuals who have worked at least five years before retirement, and then survived at least 10 year after retirement. In order to analyze the replacement rates for 
different level of income we group the mean of disposable income for the five years before retirement into quartiles. Our simulations are based on the following assumptions: a yearly inflation rate of $2 \%$, a real growth rate of $2 \%$ and a return on financial assets of $5 \%$ (relevant for all funded pension systems, including the PPM and private pensions).

The overall impression, starting with the baseline results (retirement at 65) in columns (1) and (2), is that the baby boom generation will not get a dramatic reduction in income, at least not immediately after retirement. For the average income earner the replacement rate is highest for the oldest cohort (97\%) and varies between 83 and $87 \%$ for the younger cohorts. Apart from the high rate for the 1937 cohort, there is no evidence that the new pension system reduces the replacement rate. Table 24 also shows that the replacement rate drops with increasing age. Compare, for instance, columns (1) and (2). For the cohort born 1955 the drop is around 10 percentage points. The reason for this drop in income is that both private pension savings and some funded parts of the occupational pensions are only paid out during a few years after retirement. The funded components are more important for the younger cohorts. ${ }^{19}$

As expected replacement rates varies with the level of income, from about 70 per cent in the highest income quartile to more than 100 per cent in the lowest quartile. These estimates are quite stable across both cohorts and age groups. ${ }^{20}$ For the oldest there is only a small drop in the age group 70-74 compared to 65-69 (in the lowest income there is an increase). For the younger the drop is stronger and for the 1955 cohort the drop is about ten percentage points, except for the lowest income. The ceiling in the pension system explains the lower levels among high income households.

The new pension system - based on lifetime earnings - compared to the old based on the best 15 years - is designed to give a higher penalty for early retirement and a better reward for late retirement. In order to estimate this effect, Table 24 shows replacement rates by retirement age. In columns (3) and (4) there are results assuming that everyone retires at age 67 and in columns (5) and (6) at age 63. For the average income household the cost of an early retirement, column (5) compared to the baseline in column (1), is $2-7 \%$ for all cohorts except the oldest (11\%), which does not agree with expectations. One explanation for the large effect for the oldest is that with monotonically increasing earnings, the two last years with highest earnings will not be included in the 15 best years.

A retirement postponed to the age of 67, produces a replacement rate between 91 and 98\% for the average income household and all cohorts except the oldest (102\%). The result of delaying retirement with two years is an increase in the replacement rate by about 5\% for those born 1937-1940 and 7-13\% for all others. But late retirees are not always rewarded; see the richest quartile for cohorts 1940 and 1949.

Next, the effect of alternative returns on financial assets is considered. Table 25 presents results based on a high return of $7 \%$ (columns (1) and (2)) and a low return of 3\% (columns (3) and (4)). These should be compared to the baseline in Table 24 of $5 \%$ (columns (1) and (2)). As expected the replacement rates for the older cohorts are not affected much by the return on financial assets. The main reason is that time until retirement from our base line year 1999 is too short and also that the old pension system had fewer components for which financial returns matter. However, for the younger the effect is larger, for instance, for the 1952 cohort the household in the average income category have a replacement rate between 76 and 85\% depending on the rate of return. The largest effect of differences in financial return we find for low income earners in the youngest cohort. For example, the replacement

\footnotetext{
${ }^{19}$ Indexation also matters and this will be discussed further below.

${ }^{20}$ The exception being the oldest cohort, with a rate well above $100 \%$ for the low income earners. This can partly be explained by an average before retirement income based on three years only, since individuals born in 1937 are 62 years old in 1999, at the start of the simulation.
} 
rate for the 1955 cohort increases from $92 \%$ to $108 \%$ when the rate of return increases from three per cent to seven per cent.

The conclusion is that if we base our estimates on disposable income, most rates for all scenarios are reasonable high. In fact, all replacement rates for low and average income earners are above $70 \%$. The low rates are found among the high income households and for the second five year period after retirement. For instance high income households with an early retirement, column (6) in Table 24, only gives a rate between 57 and 64\%.

In evaluating these results it is important to remember that we study a "homogenous" sample of individuals that have worked before retirement. Thus, the sample members had high incomes. If the comparison had also included other groups such as unemployed, disabled pensioners etc, then the replacement rates would have be even higher.

Disposable income is a household concept which includes other income components than labour incomes and pensions and it is net of taxes. In order to better understand the relative importance of the three pillars of the pension system, we next turn to an analysis of replacement rates based on taxable incomes. With only minor deviations taxable income before retirement is derived from labour incomes and after retirement from pensions.

As presented in Table 26, the importance of three pillars varies by income level, age and birth cohort. For individuals born in 1940 with an income in the midrange the average taxable income during the first five years after retirement is $77 \%$ of the average taxable income during the five years period before retirement. The major component is public pensions ( $56 \%$ of taxable income before retirement). Occupational and private pensions have about equal relative importance ( $10 \%$ of taxable income before retirement). ${ }^{21}$ The replacement ratio in the second five-year period drops to $69 \%$ and the main reason is the decrease in the private pensions. The occupational pension drops only slightly, because for this cohort most systems are based on defined benefits paid for life.

Private pensions are more important for older cohorts. This might be a result of underestimation of private savings for younger cohorts. Remember that individuals born in 1940 were 59 year old when the simulation started, and thus most of their savings were known from data, while most of the savings of younger cohorts have been imputed during the simulation. An interesting finding is that those private pensions are quite important for lowincome earners.

For young high-income earners, the public pension component covers just a little more than $30 \%$ of pre-pension taxable income. The reason is that many are not fully compensated because they have incomes above the ceiling. What is not obtained from the public system is however partly recovered from the occupational pensions.

A more complete picture of the economic situation of the retired would not only include incomes but also wealth that can be made liquid for consumption. This issue is discussed in the next chapter.

\subsection{Comparing different measures of replacement rates}

Following the broad discussion from Section 6.1, the purpose of this section is to evaluate different measures of the replacement rate. The importance of the definition of pre-retirement income as well as the sample used for the calculations has been considered. For the sake of simplicity all calculations are based on the cohort born 1950 and involve only the income from the public pension. The following five definitions on pre retirement income has been used; average income last 5, 10, 15 years before retirement, income at age 64 and finally at

\footnotetext{
${ }^{21}$ Note that the components do not add up exactly to taxable income, this is because taxable income can also include income from other sources, for instance income from capital.
} 
age 55. These definitions correspond to columns 1-5 in Table 27. The following samples has also been used; (1) all individuals regardless of working status before retirement, (2) only individuals that have worked at least 5 years before retirement, (3) same as (2) but with an alternative earnings equation and finally (4) only individuals with more than 30 years of pension rights and income below the ceiling. These four different samples are included in the rows of Table 27 as well as in figure 14 .

From Figure 14 it follows that, as expected, the sample of individuals working prior to retirement had the highest level of earnings. The reason for the monotonically increase until age 64, in Figure 14, is the assumed real wage increase of $2 \%$ per year. In order to test the sensitivity of the earnings profile an alternative profile is constructed by forcing earnings to decline the last four years prior to retirement. Thus, the alternative earnings equation does not have any support in the data but should only be considered as a test of the sensitivity of earnings profile prior to retirement. Figure 14 also includes the earnings profile based on all individuals, regardless of working history. This produces a considerable lower life earning profile. At any age from 49 and up, a large share of individuals is not working, as expected; this share becomes larger at older ages and therefore the average earnings decline from age 56 and at an accelerating pace from age 60. Thus, prior to retirement a large share are not working and the replacement rate based on this sample thus includes all kind of transitions such as from unemployment and disability pension. Even if we argue that the most relevant calculation of replacement rates are for the transition from work to retirement, it is nonetheless interesting to evaluate the effect of including other transitions. The final sample included in Figure 14 is based on individuals who have worked at least 30 years (30 years of pension rights) and with an income below the ceiling. The reason why this definition is of interest is because this is used by the Swedish National Social Insurance Office (NSIO), see Annual Report (2004). Thus, this definition has a special importance since this is the one used for calculations of the "official" replacement rates in Sweden; it is noteworthy that this measure produces the lowest level of the earning profile.

For the cohort born 1950, Table 27 reports all the 20 replacement rates according to the definitions discussed above. Even if Table 27 includes many entries, note that only two dimensions are considered; the sample used in the calculations which determines the level of the earnings profile and which period before retirement to consider. Of course, several choices for post retirement income could also been used, but in order to keep it simple all calculations after age 65 are based on average income during the age interval 6569.

Column 1 in table 27 lists the results based on average earnings 60-64. This definition is more sensitive for the curvature in the income profile than the results in column 2 , based on 55-64 but less sensitive than the results in column 5, income at 64 . If income is based on the whole age range, column 3, or a peak year, column 4, the result is not dependent on the curvature, only the level. Regardless of the definition of pre retirement income the highest replacement rate are always produced for the sample based on the NSIO definition (row 3). The second highest is obtained if the calculations are based on all individuals (row 1), followed by individuals that worked before 65 with an adjusted earnings equation (row 4 ). The lowest rate are obtained in row 2 and based on individuals working before 65 . This ranking follows immediately from the ranking of earnings in Figure 14, a lower earning before retirement implies a higher replacement rate.

Even if the ranking of the results are trivial, the levels are not. For instance, if income before retirement is evaluated at 64 , the rate varies from $44 \%$ to $68 \%$. The reason for this huge difference is of course the declining income before retirement. For this reason it should be avoided to base before pension earnings on one year only. Another extreme is to use the full age range, as demonstrated in column 3 , this produce a smaller variation (from 48- 
64\%), but it implies that the individual base his expected income as a pensioner on his full life earning profile. We argue that it is more realistic to base the comparison on income towards the end of the working carrier, last 5 or 10. The benefit of using the average income over several years is also that it reduces the sensitivity of declining earnings. Column 1 (60-64) reports a replacement rate of $45 \%$ based on the working criteria (row 2), given strongly declining earnings (row 4 ) the rate goes up to 51\%. The corresponding results for column 2 based on a 10 -year period are from $47 \%$ to $49 \%$. This is an argument for using a 10 -year period for pre retirement income.

As mentioned above the calculations done by NSIO can be considered as the official rates and hence have a certain importance. It is worth noting that these calculations are based on a definition (column 1 and row 3 ) that produce the second highest rate, namely $65 \%$. Due to the importance of the NSIO result, Table 28 below tries to give some further insights into the design of these high rates.

In order to follow the standard used by NSIO, the post retirement income in Table 28 is evaluated at age 65. In the first row the results are calculated using almost the same principles as in Table 27 (column 1 and row 2), the only difference is that the in the numerator income is now defined at age 65 instead of average income at 65-69. According to Table 28, public pension at age 65 covers $45 \%$ of the average taxable income at age $60-64$, based on a sample who has worked five years before 65 . In the next row the first move towards the NSIO definition is presented; the sample is now based on all individuals with pension right more than 30 years and the income before pension is defined as the average value at age 49-64. Based on these definitions the replacement rate increase to 56\%, thus an increase by almost $30 \%$. Finally the definition above is extended by only including income below the ceiling. Of course this results in a further reduction of earnings before retirement and hence results in an even higher replacement arte. In Table 28 the resulting replacement rate is $62 \%$ and this corresponds quite well to the one reported in Annual Report (2004).

To summarize, the NSIO standard produce a high replacement rate because of low pre retirement income. This low income is obtained by including non-working individuals as well as by only considering income below the ceiling. Furthermore, the income used after retirement is income at age 65, given the discussion above regarding the design of the indexation of pension income, this produce the highest post retirement income. The conclusion is that the numbers by NSIO can not be considered as a guide for the individual who needs a measure of the income that he can expect as a pensioner.

\section{Income and poverty}

\subsection{Relative income for the baby boomers}

The replacement rate is a measure relevant both for evaluating the need for private savings as well as the effects of changes in the pension and benefit rules. This rate reflects the expected changes in income after retirement; however it is not informative about the economic standard of a pensioner relative to the active population. A supplementary measure relates the income of the retired to the incomes of the working population. It is a measure of pension adequacy since it is basically showing the benefit level a pensioner will receive if compared to the working population. OECD (2005) report presents a similar measure, the relative pension level as an indicator of the individual pension as a proportion of economy-wide average earnings. Sweden lies in the category with a strong link between pension entitlements and pre-retirement earnings, along with countries like Finland, Austria, Luxembourg, Germany or Spain. 
This relative income measure has been simulated for seven different cohorts in the age bracket 65-90, see Figure 15. Relative income has been defined as average taxable income for each cohort and age divided by the average taxable income for all individuals aged 20-64 in the same year. Thus, we compare the income of the pensioners to that of the active population. At 65 years of age the average income of the pensioners is $74-79 \%$ of the average income for those aged 20-64. After 65 this ratio drops to $69-74 \%$ at age 69 , and then sharply down to $56-65 \%$ at age 70 . This first drop in the relative income reflects the assumption that the funded parts of the pension system are only paid out during the first five years. Because older cohorts to a large extent follow the old social security system they have no or just a small funded share, and the drop is thus considerably smaller for older cohorts compared to younger. After 70 years of age the relative income of the retired continuous to drop and at age 90 the ratio becomes as low as $42-49 \%$.

The main reason for the steady drop is the design of the price and income indexation of the old and new pension systems. The details of the adjusted income indexation are given in Swedish National Social Insurance Office (NSIO), see Annual Report (2004), but in short the pension is calculated as follows. The income pension is calculated by dividing the pension balance by an annuity divisor. There is a specific divisor for each birth cohort, and this divisor reflects the expected life length at the time of retirement but also an interest of 1,6 percent. The income pension is revalued annually by the change in the income index less the interest of 1.6 percentage points credited in the divisor. This means that pensions will only be unchanged in real term if income increases exactly 1.6 percent more than inflation. Applied to the assumptions used here -income increases 2 percent more than inflation - this implies that pensions increase by 0,4 percent in real term. Thus, our assumptions and the indexation described above imply a higher relative income at age 65 but it will decrease at a faster rate, this is sometimes referred to as a front loaded system.

Of course, it is important to remember that this is a result based on a 25 year simulation and as always forecasted values must be interpreted with care. One attempt to assess the realism in these seemingly low relative incomes for the very old is presented below. In Figure 16 we compare the relative income for the year 2003 based on both observed data in LINDA as well as simulated in SESIM. Thus, data have been simulated from 1999 to 2003 and then compared to "real data" for 2003, the last year available in LINDA.

The simulated data are close to the observed up to the age of 50, and then SESIM produces lower levels until they converge again at about age 70. Why does SESIM underestimate the income ratio in the age interval 50-70? It must be remembered that SESIM is estimated based on data from 1999 or earlier and major changes thereafter are not "in the estimates". A comparison of the similarly defined income based on Linda 1999, shows that a major change in the relative income occurred 1999-2003 for those aged 55-60. For instance, at age 60 the relative income was about 116\% in 2003 compared to only 106\% in 1999. Thus, relative income for individuals in the age of 55-60 has gone up since 1999 and this increase is not reflected in SESIM, and as a consequence the simulated income is underestimated. Obviously it is difficult to base information on future relative incomes on only one cross section in 2003. It is difficult to tell if the change from 1999 to 2003 reflects a permanent change or if it reflects a cohort or business cycle effect. Inspection of Figure 5b in section 3 above shows an interesting cohort effect for females. Those born in 1940 had a considerably higher labour force participation rate in 2003 compared to the 1937 cohort. If the same will be the case also for younger cohorts is an open question. Even if the income rate might be underestimated a little in the age bracket 55-70, the downward trend seems robust. The pension system is not able to maintain the relative income standard of the elderly. There is no difference in this respect between the old and the new pension system, and according to our simulations the new system actually gives lower income rates. 
The low levels of average relative income for pensioners raise the important issue of the inequality of income. If the average income for a pensioner at age 80 is only $50 \%$ of the contemporaneous income of workers, how small is income at the lowest quartile?

Table 29 below shows the result for three cohorts and for three levels of relative income; at first quartile, median and third quartile. At age 65 the range in relative income is from 0.52 to 0.93 for the oldest cohort and from 0.55 to 0.92 and 0.56 to 0.89 for the two youngest. For the lowest income there is only a small drop in relative income until age 90. The major reason for is that the funded part of the pension portfolio is small and therefore income does not drop at age 69, however as expected the drop is larger for the youngest cohort. For the average income group the cross cohort differences are quite small, at age 65 slightly above 0.7 and at age 90 is 0.48 for the oldest and around 0.4 for the youngest. The high income pensioners have a relative income about 0.9 for all cohorts at age 65 . Here, the drop after age 69 is substantial, about $10 \%$ for the oldest and more than $15 \%$ for the youngest cohort. These groups have a large share of funded components. Anyway, the relative income level of the pensioners related to economy wide average earnings is decreasing both across cohorts and with age for all income categories. The only difference is for the lowest income category, where we see a slightly increase across cohorts but only for the period immediately after retirement, namely for age interval 65- 69, followed again by a decrease.

\subsection{Income distribution and poverty}

The discussion above has been focused on replacement rates and average pensions in relation to average incomes. It is also of importance to discuss the distribution of income for the ageing population. In Figure 29 the distribution of disposable income is presented for the cohort born in 1949 as it ages. In contrast to the previous section these results are based on an unbalanced panel. We simulate future income for all individuals in the 1949 cohort from age 50 (start year 1999) up to age 90. Everyone is assumed to retire no later than at age 65. For each simulated year the first decile, first quartile, median, third quartile and ninth decile of the income distribution is calculated and presented in the figure. The general trend is a reduction in income inequality as this cohort ages. At the lower end of the income distribution this is due to an increase in income after retirement. Because this graph is drawn using all individuals, without any pre-retirement work condition, we include many low income earners who do not work just before retirement. For these individuals income goes up at retirement because both accumulated pension rights and the guarantee pension give a higher pension income. On the other hand, at higher income levels, retirement results in an income reduction. This is in line with the results discussed above, due to the ceiling in the pension system, high income earners have lower replacement rates. The compression in the income distribution is further accelerated at the age of 70 when income from private pension and funded occupational pensions are exhausted. To summarise; the ratio of decile 9 over decile 1 is about 4 shortly before pension, drops to 2,7 shortly thereafter and is then further reduced after age 70 to slightly above 2 . The increasing trend in income after retirement comes from the assumption of a $2 \%$ real wage increase, which through the indexation of pensions as discussed above, gives an yearly real increase of $0,4 \%$ in public pensions. Similar results apply to other cohorts, income dispersion is reduced after retirement.

There are alternative measures of income inequality that might give a slightly different picture. One natural candidate is the Gini coefficient which is more sensitive towards changes in the centre of the distribution. Table 30 presents the average Gini measure for age intervals of five years and a number of birth cohorts. For the younger cohorts for which it is possible to compute the Gini before retirement, we find that inequality increases up to age 6064, while there is no clear trend after retirement. There is no trend for the older cohorts either 
and no clear differences between cohorts. Thus, the pension system affect the income distribution mostly by reducing the highest and increasing the lowest incomes, but does not have any large impact on the distributions of intermediate incomes.

In the discussion of the effects of the pension system on the income distribution it is natural to focus on the low income households. The identification of poverty amongst pensioners is an old research and policy issue, and public pensions are - at least in theory designed to keep most of the elderly out of poverty. An attempt to identify the incidence of future poverty amongst the Swedish baby-boom generation is given in Figure $18{ }^{22}$ Thus, the median disposable income for the adult population has been calculated each year from 1999 to 2040, and then for the individuals belonging to the baby-boom cohorts the share with an income below half the median is recorded. For four of these cohorts the results are summarized in Figure 18. Due to falling labour force participation shortly before retirement, poverty increases before age 65. Because everyone is included in these calculations regardless of working status, many households have a low income before retirement. The poverty rate drops directly after 65, because the pension system offers a better low income guarantee than other social insurance benefits. However, shortly after retirement the poverty ratio starts to increase again and at faster rate for the younger cohorts than for the older. For instance at age 80 the poverty rate for the 1955 cohort is $25 \%$ compared to about $15 \%$ for the two oldest cohorts and at age 90 this difference has increased. The poverty rate of the 1937 cohort is about 20 per cent and that of the 1955 cohort as high as 36 per cent. The rates at this high age should, however, be interpreted with care because the number of individuals is rather few at this age.

The fast increase in poverty is consistent with the drop in relative earnings reported in Figure 15. As time passes the indexation of the pension system erode the purchasing power of public pensions, resulting in a lower relative earnings as well as a higher incidence of poverty amongst the old.

\section{Conclusions}

The findings in this chapter highlight the importance of a longitudinal analysis and provide a strong argument for the dynamic micro simulation approach. A major result is that the income standard of the young-old will become much higher than that of the very old. If our simulations bear the stamp of realism they suggest that we will see new and large poverty in Sweden among the very old in the future. The pension system contributes to this result. The "front loaded" design gives with its reduced wage indexation a higher income immediately after retirement but a much lower income at older age. From this perspective it is unfortunate that so much attention is given to the discussion of replacement rates. The replacement rate, although interesting in itself, completely miss the long run effect and just provides a comparison of incomes shortly after with incomes before retirement. If we instead focus on the relative income of older pensioners the results become quite different, as evident from Figures 15 and 18.

Our results challenge the conception of a sustainable pension system. If the relative income of older pensioners drops and at the same time expenditures for health and care increase, one might wonder how the old in our society will make both ends meet. If pensions become too small to meet "minimum standards" the requirement of financial sustainability of the pension system results in an increasing financial burden on other parts of the general social protection system.

\footnotetext{
${ }^{22}$ Poor is here defined as having an income below half the median.
} 


\section{References}

Andersson, B., Berg, L., and Klevmarken, A., [2001] "Inkomst- och

Förmögenhetsfördelningen för dagens och morgondagens äldre"

www.nek.uu.se/faculty/klevmark/reswork.html.

Baltagai, B.H.,[2001] “Econometric Analysis of Panel Data”, John Wiley and Sons Ltd.

Boskin, Michael and Shoven, John (1987), "Concepts and Measures of Earnings Replacement Rates during Retirement”. In Issues in Pension Economics, edited by Zvi Bodie, John Shoven and David Wise. Chicago: University of Chicago Press, 1987.

Börsch-Supan, A., Brugiavini, H. Jürges, J. Mackenbaach, J. Siegrist, G. Weber (Eds.) 2005, Health, Ageing and Retirement in Europe, MEA, Mannheim.

Butrica et. al (2003), “It’s All Relative: Understanding the Retirement Prospects of Baby Boomers”, Urban Institute.

Disney, Richard et.al (1998)."Resources during Retirement”. In Maintaining Prosperity in an Aging World: the OECD Study on the Policy Implications of Aging. OECD Paris.

Disney, Richard and Whitehouse, Edward (2002). “The Economic Well-Being of Older People in International Perspective: A Critical Review”. Luxembourg Income Study Working Paper, No.306.

Ericson, P. \& Hussénius, J. [2000] “Studiebidragen i det långa loppet”, Rapport till Expertgruppen för studier i offentlig ekonomi (ESO). Ds 2000:19

Flood, L., and Gråsjö, U., [2001] " A Monte Carlo simulation study of Tobit models”, Applied Economics Letters, 8, 581-584.

Flood, Lennart R., 2003, "Can we Afford the Future? An evaluation of the new Swedish pension system.” Paper presented at International Microsimulation Conference on Population Ageing and Health in Canberra.

Flood, L, F Jansson, T Pettersson, T Pettersson, O Sundberg and A Westerberg (2003), "The Handbook of SESIM - a Swedish dynamic micro simulation model", www.sesim.org

Gustman, Alan L. and Steinmer, Thomas L (1998). "Effects of pensions on Savings: Analysis with Data from the Health and Retirement Study”. NBER Working Paper No.6681 Cambridge, MA: National Bureau of Economic Research.

Hurd, Michael D.(1990), "Research on the Elderly: Economic Status, Retirement, and Consumption and Saving”, Journal of Economic Literature, June, pp.565-637. 
Hurd, Michael and Rohwedder, Susann. (2003) “The Retirement Consumption Puzzle:

Anticipated and Actual Declines in Spending in Retirement.” NBER Working Paper No.9586

Cambridge, MA: National Bureau of Economic Research.

Hurd, Michael and Rohwedder, Susann. (2005) "Consumption and Economic Well-Being at Older Ages: Income and Consumption-based Poverty Measures in HRS”, RAND, August.

Klevmarken, N.A., J. Lupton and F. Stafford (2003), “Wealth Dynamics in the 1980's and 1990's: Sweden and the United States”, The Journal of Human Resources, 38(2), 322-53 (Spring 2003)

Manning, W. G., N Duan, and Rogers., [1987] "Monte Carlo evidence on the choice between sample selection and two-part models”. Journal of Econometrics 35: 59-82.

Mantovani, Daniela,. Papadopoulos, F,. Sutherland, H and Tsakloglou, P., (2005), “Pension Incomes in the European Union: Policy Reform Strategies in Comparative Perspective” Iza Discussion paper No. 1537.

Minns, Richard (2001),“The Cold War in Welfare. Stock Market versus Pensions”, Verso UK

Munnell, Alicia H and Soto, Mauricio. (2005) “What Replacement Rates do Households Actually Experience in Retirement?”, Working Paper 10 - Center for retirement Research at Boston College.

OECD (2005)."Pensions at a Glance. Public Policies across OECD Countries”. OECD Paris.

Pettersson, T och T Pettersson (2003), Fördelning ur ett livscykel perspektiv, bilaga 9, LU 2003, SOU 2003:11, , Finansdepartementet, Stockholm.

Sheiner, Louise and Weil, David (1992) “The Housing Wealth of the Aged”, NBER Working Paper No.4115.

Smith, James P. (2003),'Trends and Projections in Income Replacement during Retirement”, Journal of Labour Economics, 21(4), pp.755-781.

Swedish National Social Insurance Office, Annual Report (2004).

Statistical Sweden (2003), Income distribution survey 2003, Statistiska Meddelanden HE 21 SM 0501

Steuerle, Eugene and Spiro, Christopher (2000).” Straight Talk on Social Security and Retirement Policy, No.24,No.25, No.26, Urban Institute.

Quinn, Joseph (1987),"Economic Status of the Elderly: Beware of the Mean," The Review of Income and Wealth, March, pp. 63-82.

U.S. Congressional Budget Office (2003), "Baby Boomers Retirement Prospects: An Overview”. November, Washington, DC. 
Venti, Steven F. and Wise, David A. (1989),’Aging, Moving, and Housing Wealth”, In Wise(ed) The Economics of Aging, University of Chicago Press

Venti, Steven F. and Wise, David A. (2001),”Aging and Housing Equity: Another Look”, NBER Working Paper No.8608. Cambridge, MA: National Bureau of Economic Research

Whiteford, Peter (1995), “The Use of Replacement Rates in International Comparisons of Benefit Systems”, SPRC Discussion Paper No.54, Social Policy Research Center, UK.

Whitehouse, Edward (2003), "The Value of Pension Entitlements: A Model of Nine OECD Countries”, OECD, DELSA/ELSA/WD/SEM(2003)9 


\section{Tables}

Table 1. Shares of pensioners and workers by age for selected OECD countries.

\begin{tabular}{|c|c|c|c|c|c|c|c|c|c|c|}
\hline Age & tatus & ermany & inland & veden & aly & pain & ustria & UK & USA & orv \\
\hline & & Male & & & & & & & & \\
\hline \multirow[t]{2}{*}{ 51-55 } & Pen & 3,8 & 7,3 & 6,8 & 34,8 & 0 & ---- & 9,0 & 4,6 & 4,9 \\
\hline & Mar & 84,6 & 85,5 & 89,8 & 65,2 & 87,5 & ---- & 85,1 & 92,3 & 91,8 \\
\hline \multirow[t]{2}{*}{$56-60$} & Pens & 16,3 & 24,1 & 9,7 & 57,7 & 7,6 & 54,8 & 14,5 & 10,7 & 12,1 \\
\hline & $\mathrm{Ma}$ & & 64,3 & 87,9 & 38,2 & 61,1 & 7,9 & 66,0 & 0,8 & 35,0 \\
\hline \multirow[t]{2}{*}{ 61-65 } & Pens & 69,8 & 69,7 & 8,2 & 79,2 & 48,4 & 94,7 & 42,1 & 33,7 & 38,3 \\
\hline & Mar & 24,7 & 28,1 & 8,6 & 18,2 & 27,6 & 4,6 & 35,8 & 58,7 & 58,2 \\
\hline \multirow[t]{3}{*}{$66-70$} & Pens & 93,0 & 95,5 & 87,6 & 94,0 & 96,2 & 100,0 & 87,5 & 59,0 & 80,4 \\
\hline & Mar & 6,4 & 4,5 & 12,4 & 5,3 & 2,2 & 0 & 12,5 & 33,7 & 18,1 \\
\hline & & male & & & & & & & & \\
\hline \multirow[t]{2}{*}{ 51-55 } & Pen & 9,3 & 6, &, 3 & 11 & 0 & 3,8 & --- & 7,3 & 13,9 \\
\hline & Mar & 60,0 & 80,8 & 83,9 & 29,0 & 23,3 & 46,2 & 66,7 & 70,9 & 74,0 \\
\hline \multirow[t]{2}{*}{$56-60$} & Pen & 1 & 21,8 & ,2 & 26,3 & 0 & 34,3 & 14,8 & 15,7 & 20,3 \\
\hline & $\mathrm{Ma}$ & & 0 & 6 & 17,5 & 18,9 & 19,8 & 48,4 & 61,9 & 65,4 \\
\hline \multirow[t]{2}{*}{ 61-65 } & Pens & 68,7 & 70,7 & 49,3 & 50,9 & 8,3 & 59,6 & 81,3 & 41,0 & 38,1 \\
\hline & Mar & 9,9 & 24,2 & ,4 & 4,5 & 7,4 & 2,2 & 18,7 & 39,8 & 44,6 \\
\hline \multirow[t]{2}{*}{$66-70$} & Pens & 91,6 & 98,1 & 93,6 & 61,5 & 31,5 & 52,1 & 93,5 & 66,5 & 77,8 \\
\hline & Market work & 2,5 & 1,9 & 6,4 & 1,1 & 1,4 & 2,1 & 6,5 & 18,8 & 15,3 \\
\hline
\end{tabular}

Source: Luxemburg Income Studies (LIS)

Note: No information available for Holland or Canada.

Table 2. Estimates of models for financial wealth

\begin{tabular}{|c|c|c|c|c|}
\hline \multirow[t]{3}{*}{ Variable } & \multicolumn{4}{|c|}{ If not financial wealth in the previous year } \\
\hline & \multicolumn{2}{|c|}{ Logit model } & \multicolumn{2}{|c|}{ Robust regression } \\
\hline & Est. & Std & Est. & Std. \\
\hline Intercept & 0.60048 & 0.0238 & 4.11968 & 0.0740 \\
\hline Age -24 & -0.88498 & 0.0165 & -0.38918 & 0.0593 \\
\hline $25-29$ & -0.69736 & 0.0143 & -0.23525 & 0.0517 \\
\hline $30-34$ & -0.81919 & 0.0148 & -0.09806 & 0.0527 \\
\hline $35-39$ & -0.93684 & 0.0153 & -0.11248 & 0.0544 \\
\hline $40-44$ & -1.04328 & 0.0157 & -0.08929 & 0.0565 \\
\hline $45-49$ & -1.16899 & 0.0160 & -0.13599 & 0.0572 \\
\hline $50-54$ & -1.14642 & 0.0160 & -0.1094 & 0.0565 \\
\hline $55-59$ & -1.08049 & 0.0165 & 0.10601 & 0.0588 \\
\hline $60-64$ & -0.90114 & 0.0178 & 0.01721 & 0.0631 \\
\hline $65-69$ & -0.733 & 0.0189 & 0.1681 & 0.0672 \\
\hline $70-74$ & -0.65676 & 0.0189 & 0.05592 & 0.0675 \\
\hline $75-79$ & -0.43381 & 0.0183 & 0.05422 & 0.0647 \\
\hline \multicolumn{5}{|l|}{$\begin{array}{l}\text { Taxable } \\
\text { income }\end{array}$} \\
\hline - P25 & -2.60493 & 0.0216 & -0.57373 & 0.0653 \\
\hline P25 - P50 & -2.13505 & 0.0212 & -0.55061 & 0.0632 \\
\hline P50 - P75 & -1.57561 & 0.0212 & -0.57211 & 0.0627 \\
\hline P75 - P90 & -1.04016 & 0.0219 & -0.5316 & 0.0653 \\
\hline P90 - P95 & -0.61007 & 0.0262 & -0.31861 & 0.0788 \\
\hline
\end{tabular}


Table 3. Estimates of a dynamic model for financial wealth

\begin{tabular}{|c|c|c|c|}
\hline \multicolumn{2}{|l|}{ Variable } & Est. & $\overline{\text { Std }}$ \\
\hline \multicolumn{2}{|l|}{ Intercept } & 0.95 & --- \\
\hline \multicolumn{2}{|c|}{ Lag stock * Age -24} & -0.01779 & .0017145 \\
\hline Lag stock $*$ & $25-29$ & -0.01527 & .0010651 \\
\hline Lag stock * & $30-34$ & -0.01836 & .0009241 \\
\hline Lag stock $*$ & $35-39$ & -0.01697 & .0008114 \\
\hline Lag stock * & $40-44$ & -0.01633 & .0007732 \\
\hline Lag stock * & $45-49$ & -0.01511 & .0007468 \\
\hline Lag stock * & $50-54$ & -0.01153 & .0007256 \\
\hline Lag stock $*$ & $55-59$ & -0.0066 & .0006901 \\
\hline Lag stock * & $60-64$ & -0.00515 & .000701 \\
\hline Lag stock * & $65-69$ & -0.00329 & .0006928 \\
\hline Lag stock * & $70-74$ & -0.00188 & .0006632 \\
\hline Lag stock * & $75-79$ & 0.00036 & .0006397 \\
\hline \multicolumn{4}{|c|}{ Taxable income } \\
\hline Lag stock * & - P25 & 0.04294 & .0074007 \\
\hline Lag stock * & $25-P 50$ & 0.03045 & .0073334 \\
\hline Lag stock * & $50-P 75$ & 0.01779 & .0073631 \\
\hline Lag stock $*$ & $75-\mathrm{P} 90$ & 0.01147 & .0076342 \\
\hline Lag stock * & $90-$ P95 & 0.00296 & .0090645 \\
\hline & & -0.4743 & .0129215 \\
\hline & $5-P 50$ & -0.35605 & .0128246 \\
\hline & $0-$ P75 & -0.25246 & .0128674 \\
\hline & $5-P 90$ & -0.1863 & .0132784 \\
\hline & $0-\mathrm{P} 95$ & -0.09846 & .0156584 \\
\hline Index Sthlm & ock Exch. & 0.00408 & .0000107 \\
\hline Lagged stock & f financial assets & 0.88323 & .0071054 \\
\hline Sigma_u & & 0.01979 & \\
\hline Sigma_e & & 0.3732 & \\
\hline
\end{tabular}


Table 4. Tax-deferred pension savings 1980-2000

\begin{tabular}{|c|c|c|c|c|c|c|c|c|}
\hline & $\begin{array}{c}\text { Share } \\
\text { with } \\
\text { pension } \\
\text { savings }\end{array}$ & $\begin{array}{c}\text { Mean } \\
\text { value } \\
\text { given } \\
\text { savings }\end{array}$ & $\begin{array}{l}\text { Share } \\
\text { with } \\
\text { income } \\
\text { from } \\
\text { pension } \\
\text { savings } \\
(\%)\end{array}$ & $\begin{array}{c}\text { Mean } \\
\text { value } \\
\text { given } \\
\text { income }\end{array}$ & $\begin{array}{c}\text { Share } \\
\text { with } \\
\text { pension } \\
\text { wealth }\end{array}$ & $\begin{array}{c}\text { Mean } \\
\text { value } \\
\text { given } \\
\text { pension } \\
\text { Wealth } \\
\text { (tkr) }\end{array}$ & $\begin{array}{c}\text { Sum of } \\
\text { pension } \\
\text { wealth }\end{array}$ & $\begin{array}{l}\text { Assumed } \\
\text { return } \\
\text { on } \\
\text { savings }\end{array}$ \\
\hline 1980 & 4.60 & 3529 & 0.00 & 936 & 4.10 & 3882 & 1396 & 10 \\
\hline 1981 & 4.70 & 3962 & 0.00 & 1416 & 4.40 & 8086 & 3137 & 10 \\
\hline 1982 & 4.90 & 4748 & 0.00 & 981 & 4.70 & 13136 & 5449 & 10 \\
\hline 1983 & 3.80 & 6968 & 0.00 & 2127 & 4.80 & 19728 & 8411 & 12 \\
\hline 1984 & 4.40 & 7846 & 0.00 & 1469 & 5.00 & 28427 & 12550 & 13 \\
\hline 1985 & 8.20 & 8321 & 0.00 & 1427 & 5.40 & 39080 & 18828 & 15 \\
\hline 1986 & 8.50 & 9229 & 0.70 & 11621 & 6.90 & 43074 & 26553 & 14 \\
\hline 1987 & 9.70 & 9969 & 0.80 & 14074 & 8.70 & 46748 & 36056 & 12 \\
\hline 1988 & 11.90 & 11170 & 0.70 & 7676 & 11.00 & 51523 & 50285 & 14 \\
\hline 1989 & 14.40 & 12955 & 0.70 & 8027 & 13.60 & 62291 & 74903 & 21 \\
\hline 1990 & 14.50 & 8138 & 0.70 & 8319 & 15.50 & 69798 & 95710 & 16 \\
\hline 1991 & 12.50 & 9656 & 2.60 & 21013 & 17.20 & 73414 & 111944 & 10 \\
\hline 1992 & 12.80 & 8339 & 2.90 & 22175 & 18.50 & 76117 & 125012 & 8 \\
\hline 1993 & 13.30 & 8465 & 3.30 & 23476 & 19.50 & 79001 & 136367 & 6 \\
\hline 1994 & 15.00 & 8762 & 3.50 & 23572 & 21.40 & 80551 & 152702 & 9 \\
\hline 1995 & 16.20 & 6861 & 4.10 & 22528 & 23.00 & 82478 & 168393 & 8 \\
\hline 1996 & 17.30 & 6764 & 4.10 & 23608 & 24.60 & 85822 & 187482 & 10 \\
\hline 1997 & 18.20 & 6705 & 4.20 & 25272 & 26.10 & 92546 & 214326 & 14 \\
\hline 1998 & 19.20 & 6659 & 4.30 & 27870 & 27.80 & 100973 & 248870 & 16 \\
\hline 1999 & 20.50 & 6785 & 4.50 & 30540 & 29.70 & 104530 & 275265 & 10 \\
\hline 2000 & 21.90 & 6591 & 4.80 & 32598 & 32.00 & 110863 & 315101 & 16 \\
\hline
\end{tabular}

Note, own calculations based on the Linda panel 1980-2000. Information on average returns, in column (9), comes from The Swedish Insurance Federation (www.forsakringsforbundet.com). Note, these returns are returns before tax and administrative costs. 
Table 5. Tax tax-deferred pension savings, logit for the probability of investing if no stock in previous year, and OLS for amount invested.

\begin{tabular}{|c|c|c|c|c|c|c|}
\hline & Logit mod & & & OLS mo & del & \\
\hline & $\begin{array}{l}\text { Parameter } \\
\text { estimate }\end{array}$ & $\begin{array}{l}\text { r Standard } \\
\text { error }\end{array}$ & $\begin{array}{l}\text { dProb } \\
\text { value }\end{array}$ & $\begin{array}{l}\text { Odds } \\
\text { ratio Paramete } \\
\text { estimate }\end{array}$ & $\begin{array}{l}\text { erStandarc } \\
\text { error }\end{array}$ & $\begin{array}{c}\text { dProb } \\
\text { value }\end{array}$ \\
\hline Intercept & -2.4561 & 0.0393 & $<.0001$ & 14.22205 & 1.15525 & $<.0001$ \\
\hline $0=$ male, $1=$ female & 0.4683 & 0.00561 & $<.0001$ & 11.597-0.19470 & 0.16651 & 0.2423 \\
\hline Age & 0.0353 & 0.00183 & $<.0001$ & 11.036-0.25838 & 0.05442 & $<.0001$ \\
\hline Age squared / 100 & -0.0973 & 0.00228 & $<.0001$ & 10.9070 .59683 & 0.06965 & \\
\hline Basic education & -0.4502 & 0.00883 & $<.0001$ & $10.637-1.65896$ & 0.26264 & $<.0001$ \\
\hline Medium education & -0.1636 & 0.00597 & $<.0001$ & $10.849-1.07824$ & 0.17420 & $<.0001$ \\
\hline University Reference & --- & --- & --- & --- --- & --- & --- \\
\hline Marital Status 1=married & 0.0227 & 0.00569 & $<.0001$ & 11.023 & & \\
\hline Tax inc $<=$ p25 & -1.7720 & 0.0153 & $<.0001$ & $10.170-6.39336$ & 0.43988 & $<.0001$ \\
\hline p $25<$ Tax inc $<=$ p50 & -0.5832 & 0.0140 & $<.0001$ & $10.558-7.36022$ & 0.40762 & $<.0001$ \\
\hline p50 $<$ Tax inc $<=$ p75 & -0.2468 & 0.0134 & $<.0001$ & $10.781-7.54614$ & 0.38708 & $<.0001$ \\
\hline p75 $<$ Tax inc $<=$ p90 & -0.1255 & 0.0137 & $<.0001$ & $10.882-6.69367$ & 0.39397 & $<.0001$ \\
\hline p90 $<$ Tax inc $<=$ p95 & 0.0166 & 0.0160 & 0.2974 & $41.017-5.25442$ & 0.46048 & $<.0001$ \\
\hline$>$ p95 Reference & --- & --- & --- & --- & --- & --- \\
\hline Nationality:Swedish=1 & 0.5050 & 0.0119 & $<.0001$ & 11.657-1.34359 & 0.35498 & 0.0002 \\
\hline
\end{tabular}


Table 6. Estimates of a model of the market value of single family houses in $\mathbf{2 0 0 0}$

\begin{tabular}{|c|c|c|c|}
\hline & $\begin{array}{l}\text { Parameter } \\
\text { estimate }\end{array}$ & $\begin{array}{l}\text { Standard } \\
\text { error }\end{array}$ & $\begin{array}{l}\text { Prob } \\
\text { value }\end{array}$ \\
\hline Intercept & 0.21501 & 0.04760 & $<.0001$ \\
\hline Age & 0.02748 & 0.00162 & $<.0001$ \\
\hline Age squared & -0.02881 & 0.00131 & $<.0001$ \\
\hline Marital Status 1=married & 0.22295 & 0.01371 & $<.0001$ \\
\hline Number children $<18$ & -0.000493 & 0.00549 & 0.9284 \\
\hline Tax inc $<=$ p25 & 0.16705 & 0.02972 & $<.0001$ \\
\hline p25 < Tax inc < $=$ p50 & 0.00117 & 0.02434 & 0.9618 \\
\hline p50 < Tax inc < $<$ p75 & -0.03867 & 0.01929 & 0.0450 \\
\hline $\mathrm{p} 75<$ Tax inc $<=$ p90 & -0.01329 & 0.01607 & 0.4080 \\
\hline p90 < Tax inc < = p95 & -0.03896 & 0.01074 & 0.0003 \\
\hline >p95 (reference) & --- & --- & --- \\
\hline Stockholm & 0.88275 & 0.01085 & $<.0001$ \\
\hline Gothenburg, Malmo & 0.73231 & 0.00862 & $<.0001$ \\
\hline Larger cities & 0.40752 & 0.00707 & $<.0001$ \\
\hline Southern medium urban & 0.30120 & 0.00742 & $<.0001$ \\
\hline Northern urban & 0.15413 & 0.00929 & $<.0001$ \\
\hline Rural (reference) & --- & --- & --- \\
\hline House area square meters & 0.81052 & 0.06021 & $<.0001$ \\
\hline Financial wealth $<=$ p50 & -0.58996 & 0.00739 & $<.0001$ \\
\hline p50 < Financial wealth $<=$ p75 & -0.41537 & 0.00719 & $<.0001$ \\
\hline p75 < Financial wealth $<=$ p90 & -0.27278 & 0.00729 & $<.0001$ \\
\hline p90 < Financial wealth <= p95 & -0.15499 & 0.00879 & $<.0001$ \\
\hline >p95 (reference) & --- & --- & --- \\
\hline $\mathrm{R}^{2}$ & 0.40 & & \\
\hline
\end{tabular}


Table 7. Estimates of a two-part model to explain new investments in other properties.

\begin{tabular}{|c|c|c|c|c|}
\hline \multirow[t]{2}{*}{ Variable } & \multicolumn{2}{|c|}{ Logit model } & \multicolumn{2}{|c|}{ Robust regression model } \\
\hline & Est. & Std. & & Est. \\
\hline Intercept & -4.21229 & 0.0552 & 6.070 & 0.1364 \\
\hline-24 & -1.25596 & 0.0987 & & \\
\hline $25-29$ & -0.06498 & 0.0513 & & \\
\hline $30-34$ & 0.52977 & 0.0443 & & \\
\hline $35-39$ & 0.55369 & 0.0442 & & \\
\hline $40-44$ & 0.68137 & 0.0441 & & \\
\hline $45-49$ & 0.72257 & 0.0439 & & \\
\hline $50-54$ & 0.75253 & 0.0435 & & \\
\hline $55-59$ & 0.73157 & 0.0443 & & \\
\hline $60-64$ & 0.69633 & 0.0463 & & \\
\hline $65-69$ & 0.83386 & 0.0472 & & \\
\hline $70-74$ & 0.57541 & 0.0498 & & \\
\hline $75-79$ & 0.33514 & 0.0526 & & \\
\hline $80-$ & 0.0000 & & & \\
\hline Max age in hh & & & -0.009 & 0.0017 \\
\hline If couple & 0.24162 & 0.0206 & & \\
\hline Taxable income & & & & \\
\hline - P25 & -2.0716 & 0.0420 & -0.775 & 0.1222 \\
\hline P25 - P50 & -1.58002 & 0.0381 & -0.733 & 0.1172 \\
\hline P50 - P75 & -1.16858 & 0.0355 & -0.604 & 0.1175 \\
\hline P75 - P90 & -0.74813 & 0.0367 & -0.501 & 0.1226 \\
\hline P90 - P95 & -0.50311 & 0.0449 & -0.249 & 0.1505 \\
\hline P95 - & 0.0000 & 0.0420 & 0.000 & \\
\hline No of obs. & 170673 & & 1402 & \\
\hline
\end{tabular}


Table 8. Estimates of a random effects probit model for the probability of taking up a loan if the household had no loan previously.

\begin{tabular}{|c|c|c|c|c|}
\hline Explanatory variable & Estimate & Std.err. & z-score & $\begin{array}{l}\text { Mean of } \\
\text { explanatory } \\
\text { variables }\end{array}$ \\
\hline Age 30-45 & -0.2522 & 0.0237 & -10.63 & 0.1101 \\
\hline Age $45-60$ & -0.6428 & 0.0236 & -27.19 & 0.1632 \\
\hline Age 60-75 & -1.2922 & 0.0240 & -53.71 & 0.2905 \\
\hline Age 75- & -2.0298 & 0.0263 & -77.07 & 0.3828 \\
\hline If single & -0.3758 & 0.0130 & -28.89 & 0.6170 \\
\hline Change in real assets & 0.0003 & 0.0000 & 16.75 & 21.0871 \\
\hline Change in financial assets & -0.0000 & 0.0000 & -2.53 & -21.3270 \\
\hline Lagged disposable income & 0.0001 & 0.0000 & 7.96 & 173.179 \\
\hline $\begin{array}{l}\text { Sum of change in taxable } \\
\text { income from work }\end{array}$ & -0.0001 & 0.0000 & -1.13 & 3.2775 \\
\hline Real rate of interest & -0.2742 & 0.0102 & -26.81 & 3.7600 \\
\hline Intercept & 0.9049 & 0.0469 & 19.30 & \\
\hline $\begin{array}{l}\text { Std. of individual random effect } \\
\text { component }\end{array}$ & 0.8159 & 0.0098 & & \\
\hline No of observations & 188536 & & & \\
\hline No of individuals & 59976 & & & \\
\hline
\end{tabular}

Note: Explanatory variables in values are used in the unit 1000 SEK. The interest rate is in per cent. 
Table 9. Random effects regression of the logarithm of new debts given that the household had no debt in the previous year.

\begin{tabular}{lccc}
\hline Explanatory variable & Slope estimate & Std. err. & z-score \\
\hline Age 30-45 & -0.3195 & 0.0650 & -4.92 \\
Age 45-60 & -0.6601 & 0.0660 & -10.00 \\
Age 60-75 & -1.2589 & 0.0686 & -18.34 \\
Age 75- & -1.8486 & 0.0816 & -22.66 \\
If single & -0.3047 & 0.0426 & -7.16 \\
Change in real assets & 0.0010 & 0.0001 & 18.88 \\
Lagged disposable & 0.0004 & 0.0001 & 7.88 \\
income & & & \\
Real rate of interest & -0.6098 & 0.0900 & -6.77 \\
Change in real rate of & 0.0721 & 0.0600 & 1.20 \\
interest & & & \\
Intercept & 5.1921 & 0.3468 & 14.97 \\
Sigma u & 1.5711 & & \\
Sigma e & 2.2520 & & \\
No of observations & 21583 & & \\
No of households & 20120 & & \\
\hline
\end{tabular}


Table 10. Random effects probit estimates for the probability to stay in debt.

\begin{tabular}{|c|c|c|c|}
\hline Explanatory variables & $\begin{array}{l}\text { Slope } \\
\text { estimates }\end{array}$ & Std. err. & Z-score \\
\hline Age 30-45 & -0.0773 & 0.0315 & -2.45 \\
\hline Age $45-60$ & -0.1884 & 0.0309 & -6.10 \\
\hline Age $60-75$ & -0.5062 & 0.0315 & -16.08 \\
\hline Age 75- & -0.5784 & 0.0347 & -16.65 \\
\hline \multicolumn{4}{|l|}{ Interactions: } \\
\hline (Age 16-29)*lagged log(debt) & 0.3472 & 0.0075 & 46.35 \\
\hline (Age 30-45)*lagged log(debt) & 0.3685 & 0.0044 & 83.44 \\
\hline (Age 45-60)*lagged log(debt) & 0.3595 & 0.0039 & 91.64 \\
\hline (Age 60-75)*lagged log(debt) & 0.3434 & 0.0041 & 83.73 \\
\hline (Age 75-)*lagged log(debt) & 0.2921 & 0.0056 & 51.77 \\
\hline If single & -0.0885 & 0.0096 & -9.24 \\
\hline Change in real assets & 0.0001 & 0.0000 & 22.86 \\
\hline Change in financial assets & -0.0000 & 0.0000 & -1.58 \\
\hline Lagged disposable income & -0.0000 & 0.0000 & -3.30 \\
\hline Real rate of interest & -0.3282 & 0.0201 & 16.32 \\
\hline Change in real rate of interest & 0.1649 & 0.0137 & 12.03 \\
\hline Intercept & 2.1368 & 0.0826 & 25.86 \\
\hline Sigma u & 0.5117 & & \\
\hline No of observations & 633616 & & \\
\hline No of households & 170037 & & \\
\hline
\end{tabular}


Table 11. Random effects GLS regression estimates of a model explaining the log of debts for households who continue to have debts.

\begin{tabular}{|c|c|c|c|}
\hline Explanatory variables & $\begin{array}{l}\text { Slope } \\
\text { estimates }\end{array}$ & Std. err. & Z-score \\
\hline Age $30-45$ & -0.3538 & 0.0214 & -16.51 \\
\hline Age $45-60$ & -0.5651 & 0.0216 & -26.18 \\
\hline Age 60-75 & -0.9721 & 0.0234 & -41.57 \\
\hline Age 75- & -1.1224 & 0.0319 & -35.21 \\
\hline \multicolumn{4}{|l|}{ Interactions: } \\
\hline (Age 16-29)*lagged log(debt) & -0.2209 & 0.0041 & -54.11 \\
\hline (Age 30-45)*lagged log(debt) & -0.1430 & 0.0015 & -94.11 \\
\hline (Age 45-60)*lagged log(debt) & -0.1140 & 0.0014 & -78.88 \\
\hline (Age 60-75)*lagged log(debt) & -0.0610 & 0.0023 & -26.94 \\
\hline (Age 75-)*lagged log(debt) & -0.0442 & 0.0050 & -8.81 \\
\hline Change in real assets & 0.00006 & 0.000001 & 55.14 \\
\hline Lagged disposable income & 0.000005 & 0.0000008 & 6.57 \\
\hline $\begin{array}{l}\text { Change in taxable income } \\
\text { from work }\end{array}$ & 0.000008 & 0.000004 & 2.00 \\
\hline Real rate of interest & -0.0938 & 0.0033 & -28.11 \\
\hline Change in real rate of interest & 0.0414 & 0.0023 & 18.38 \\
\hline Intercept & 1.5233 & 0.0235 & 64.69 \\
\hline Sigma u & 0.3822 & & \\
\hline Sigma e & 0.4917 & & \\
\hline No of observations & 583688 & & \\
\hline Number of households & 157016 & & \\
\hline
\end{tabular}


Table 12. Estimates of a random effect model for earnings

\begin{tabular}{|c|c|c|c|c|c|}
\hline & & \multicolumn{2}{|c|}{ Male } & \multicolumn{2}{|c|}{ Female } \\
\hline & & estimate & Std.err. & estimate & Std.err. \\
\hline \multicolumn{6}{|c|}{ Private Blue collar } \\
\hline \multicolumn{2}{|l|}{ Intercept } & 11.7355 & 0.0387 & 11.7136 & 0.0595 \\
\hline \multirow[t]{2}{*}{ Experience } & Log(experience) & 0.2630 & 0.0126 & 0.1790 & 0.0193 \\
\hline & Experiance ${ }^{2} / 100$ & -0.0224 & 0.0014 & -0.0158 & 0.0020 \\
\hline \multirow[t]{3}{*}{ Education } & Compulsory & -0.2028 & 0.0204 & -0.1907 & 0.0289 \\
\hline & Upper secondary & -0.1581 & 0.0190 & -0.1228 & 0.0266 \\
\hline & University & 1.0000 & -------- & 1.0000 & -------- \\
\hline Nationality & Swedish born = yes & 0.0791 & 0.0148 & 0.0187 & 0.0213 \\
\hline Marital status & Single = yes & -0.0021 & 0.0084 & 0.0714 & 0.0135 \\
\hline \multicolumn{2}{|c|}{ Individual variance $\tau^{2}$} & 0.0732 & & 0.0947 & \\
\hline \multicolumn{2}{|c|}{ Random variance $\sigma^{2}$} & 0.0202 & & 0.0214 & \\
\hline \multicolumn{6}{|c|}{ Private White collar } \\
\hline \multicolumn{2}{|l|}{ Intercept } & 11.7791 & 0.0718 & 11.7506 & 0,0869 \\
\hline \multirow[t]{2}{*}{ Experience } & Log(experience) & 0.3845 & 0.0257 & 0.2817 & 0,0316 \\
\hline & Experiance $^{2} / 100$ & -0.0220 & 0.0028 & -0.0231 & 0,0037 \\
\hline \multirow[t]{3}{*}{ Education } & Compulsory & -0.3588 & 0.0289 & -0.2306 & 0,0387 \\
\hline & Upper secondary & -0.2384 & 0.0172 & -0.1861 & 0,0220 \\
\hline & University & 1.0000 & ------- & 1.0000 & ------- \\
\hline \multirow{2}{*}{$\begin{array}{l}\text { Nationality } \\
\text { Marital status }\end{array}$} & Swedish born = yes & 0.0205 & 0.0278 & 0.0309 & 0,0324 \\
\hline & Single $=$ yes & -0.0436 & 0.0147 & 0.0605 & 0,0180 \\
\hline \multicolumn{2}{|c|}{ Individual variance $\tau^{2}$} & 0.1547 & & 0.1329 & \\
\hline \multicolumn{2}{|c|}{ Random variance $\sigma^{2}$} & 0.0268 & & 0.0199 & \\
\hline \multicolumn{6}{|c|}{ State Governmental } \\
\hline \multicolumn{2}{|l|}{ Intercept } & 11.6771 & 0.0950 & 11.6030 & 0,1059 \\
\hline \multirow[t]{2}{*}{ Experience } & Log(experience) & 0.3327 & 0.0337 & 0.2937 & 0,0373 \\
\hline & Experiance $^{2} / 100$ & -0.0248 & 0.0034 & -0.0203 & 0,0036 \\
\hline \multirow[t]{3}{*}{ Education } & Compulsory & -0.4261 & 0.0314 & -0.3831 & 0,0347 \\
\hline & Upper secondary & -0.2804 & 0.0206 & -0.3113 & 0,0245 \\
\hline & University & 1.0000 & ------- & 1.0000 & ------- \\
\hline \multirow{2}{*}{$\begin{array}{l}\text { Nationality } \\
\text { Marital status }\end{array}$} & Swedish born = yes & 0.1532 & 0.0378 & 0.0553 & 0,0367 \\
\hline & Single $=$ yes & -0.0936 & 0.0175 & 0.0336 & 0,0195 \\
\hline \multicolumn{2}{|c|}{ Individual variance $\tau^{2}$} & 0.1044 & & 0.0875 & \\
\hline \multicolumn{2}{|c|}{ Random variance $\sigma^{2}$} & 0.0177 & & 0.0142 & \\
\hline
\end{tabular}


Table 12. Estimates of a random effect model for earnings (continued)

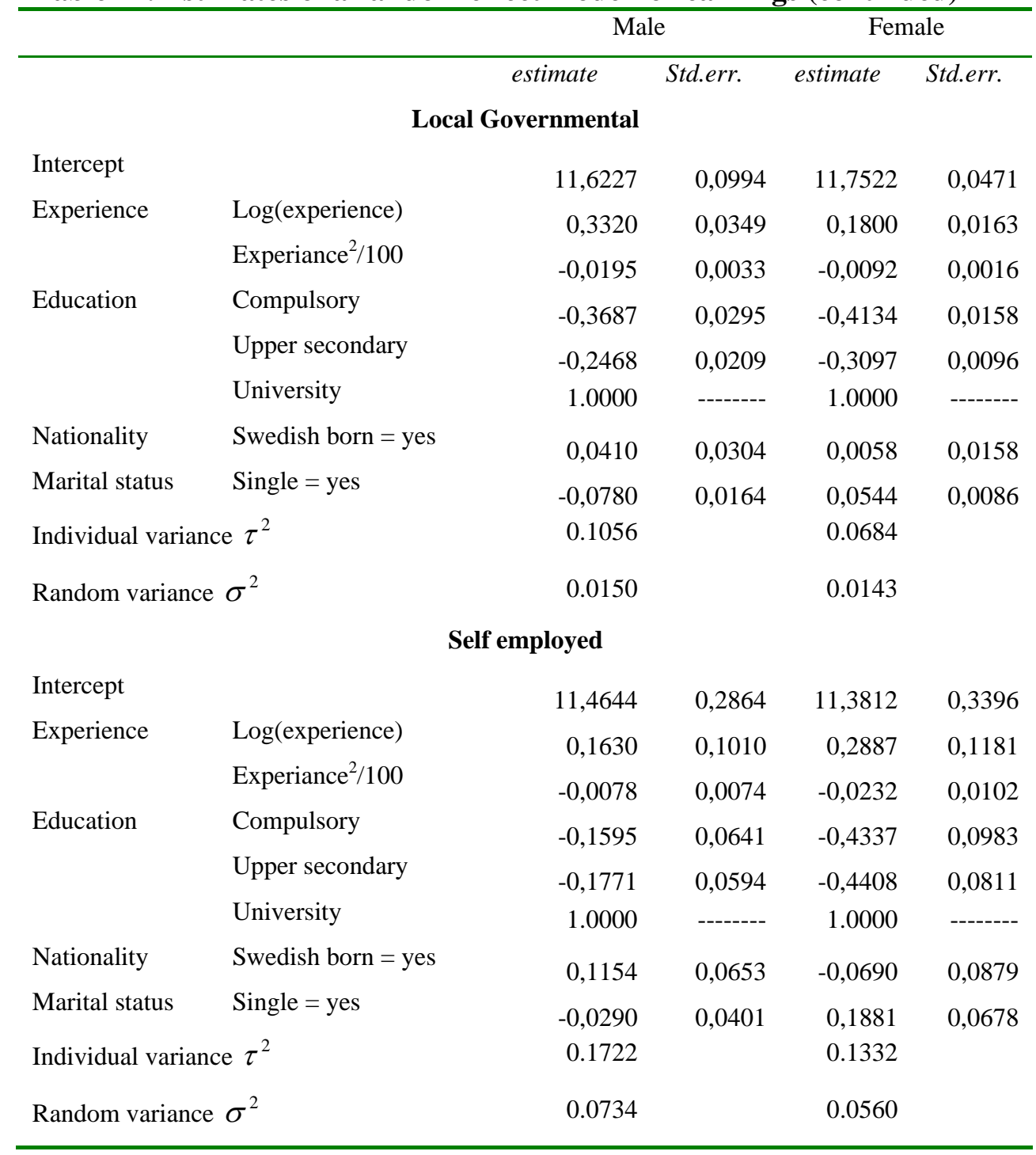


Table 13. Estimates of a tobit model for the rates of return on financial assets

\begin{tabular}{lccc}
\hline Explanatory variable & Slope estimate & Std.err. & t-score \\
If only basic schooling & -0.0030 & 0.0002 & -12.10 \\
If secondary schooling & -0.0017 & 0.0002 & -8.75 \\
If a couple & 0.0036 & 0.0002 & 20.27 \\
Age 30-44 & 0.0019 & 0.0003 & 5.59 \\
Age 45-59 & 0.0034 & 0.0003 & 9.86 \\
Age 60-74 & 0.0028 & 0.0004 & 7.62 \\
Age 75 - & -0.0005 & 0.0004 & -1.38 \\
Mean assets*10 33 & 0.0358 & 0.0029 & 12.11 \\
Mean assets*10 ${ }^{3}$ squared & -0.0065 & 0.0007 & -8.90 \\
Intercept & 0.0123 & 0.0003 & 39.26 \\
Std.err. of residual & 0.0346 & 0.0001 &
\end{tabular}

Number of observations 198900

Pseudo $\mathrm{R}^{2} \quad-0.0016$

Note: The dependent variable was a ratio in the range 0 to 0.5

Table 14. Deciles of the distribution of rates of returns on financial assets

\begin{tabular}{llll}
\hline 1 & 0.0012 & 6 & 0.0132 \\
\hline 2 & 0.0045 & 7 & 0.0157 \\
3 & 0.0068 & 8 & 0.0197 \\
4 & 0.0089 & 9 & 0.0306 \\
5 & 0.0109 & Max (after truncation) & 0.5 \\
\hline
\end{tabular}


Table 15. A probit model for the probability of having a capital gain

\begin{tabular}{|c|c|c|c|c|c|}
\hline \multicolumn{3}{|c|}{ Explanatory variable } & Slope estimate & Std.err. & t-score \\
\hline \multicolumn{3}{|c|}{ Age 30-44 } & -0.1440 & 0.0114 & -12.60 \\
\hline \multicolumn{3}{|c|}{ Age 45-59 } & -0.1989 & 0.0119 & -16.78 \\
\hline \multicolumn{3}{|c|}{ Age 60-74 } & -0.3067 & 0.0127 & -24.08 \\
\hline \multicolumn{3}{|c|}{ Age 75 - } & -0.6225 & 0.0135 & -46.05 \\
\hline \multicolumn{3}{|c|}{ If couple } & 0.1808 & 0.0068 & 26.54 \\
\hline \multicolumn{2}{|c|}{ Reduction in real estate value: } & \multirow[t]{4}{*}{ Q1 } & 0.0901 & 0.0223 & 4.04 \\
\hline -“- & Q2 & & 0.1890 & 0.0215 & 8.78 \\
\hline -“- & Q3 & & 0.2887 & 0.0208 & 13.86 \\
\hline -“- & Q4 & & 0.2735 & 0.0213 & 12.86 \\
\hline \multicolumn{2}{|c|}{ Increase in real estate value } & \multirow[t]{4}{*}{ Q1 } & 0.1367 & 0.0098 & 13.95 \\
\hline -“- & Q2 & & 0.1779 & 0.0099 & 18.03 \\
\hline -“- & Q3 & & 0.2154 & 0.0100 & 21.58 \\
\hline -“- & Q4 & & 0.1978 & 0.0106 & 18.63 \\
\hline \multicolumn{2}{|c|}{ Reduction in financial wealth } & \multirow[t]{4}{*}{ Q1 } & 1.6891 & 0.0169 & 99.71 \\
\hline -“- & Q2 & & 1.8980 & 0.0170 & 111.87 \\
\hline -“- & Q3 & & 2.0762 & 0.0171 & 121.69 \\
\hline -“- & Q4 & & 2.3603 & 0.0174 & 135.01 \\
\hline \multicolumn{2}{|c|}{ Increase in financial wealth } & \multirow[t]{4}{*}{ Q1 } & 1.1840 & 0.0165 & 71.75 \\
\hline -“- & Q2 & & 1.3864 & 0.0163 & 84.79 \\
\hline -“- & Q3 & & 1.5853 & 0.0163 & 97.23 \\
\hline -“- & Q4 & & 2.0414 & 0.0166 & 123.26 \\
\hline \multicolumn{3}{|c|}{ Gross wealth relative to median gross wealth } & 0.0390 & 0.0010 & 38.03 \\
\hline \multicolumn{3}{|c|}{ Intercept } & -2.1202 & 0.0156 & -135.95 \\
\hline \multicolumn{3}{|c|}{ Number of observations } & 245166 & & \\
\hline \multicolumn{3}{|c|}{ Pseudo $\mathrm{R}^{2}$} & 0.2053 & & \\
\hline
\end{tabular}


Table 16. The probability to have a capital loss conditional on no capital gain

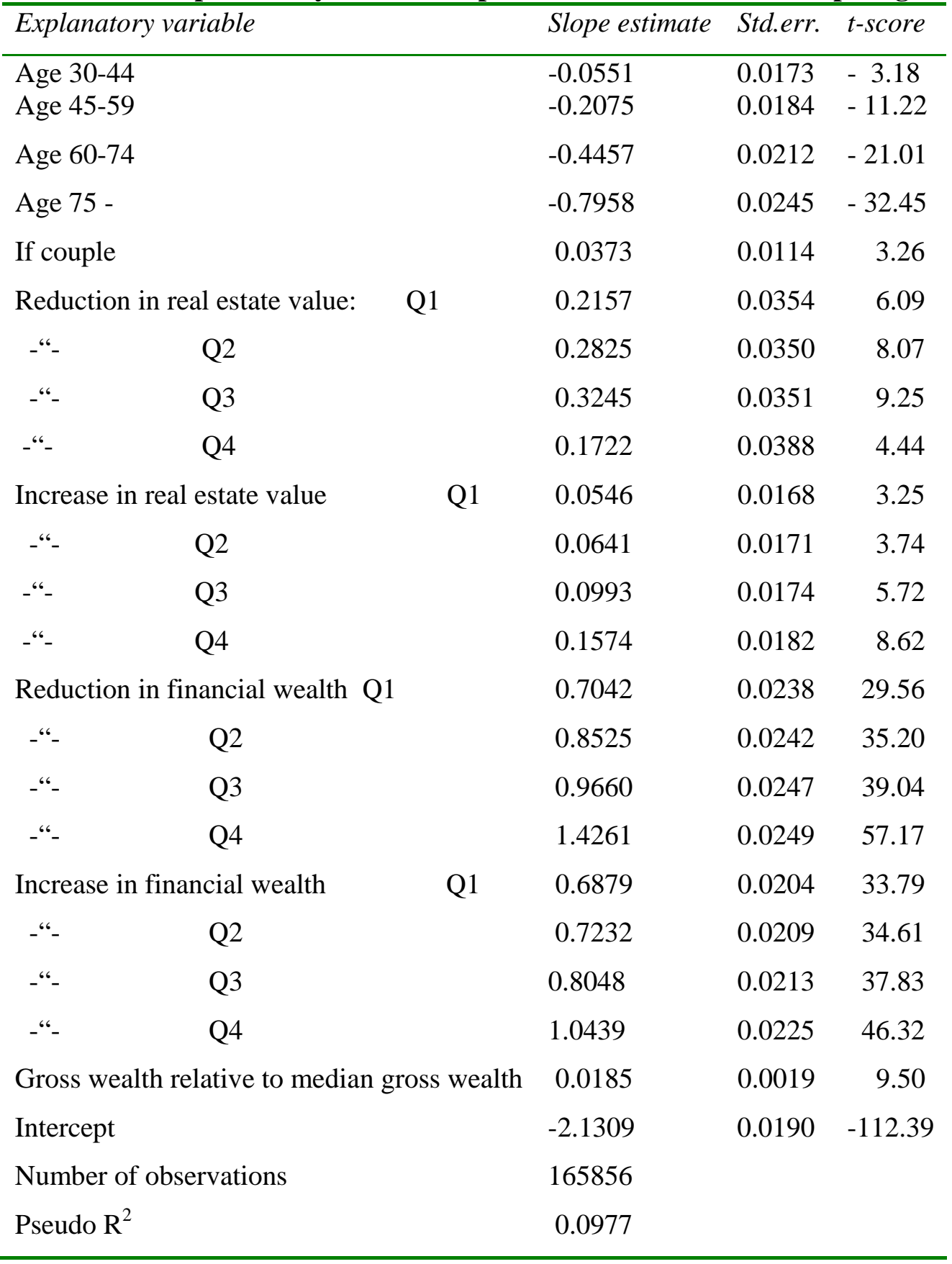


Table 17. Robust regression of the size of the capital gains, if the household gained.

\begin{tabular}{|c|c|c|c|c|c|}
\hline \multicolumn{3}{|c|}{ Explanatory variable } & Slope estimate & Std.err. & t-score \\
\hline \multicolumn{3}{|c|}{ Age 30-44 } & -238.45 & 189.34 & -1.26 \\
\hline \multicolumn{3}{|c|}{ Age 45-59 } & 392.11 & 194.31 & 2.02 \\
\hline \multicolumn{3}{|c|}{ Age 60-74 } & 1648.06 & 206.40 & 7.98 \\
\hline \multicolumn{3}{|c|}{ Age 75 - } & 2251.64 & 228.78 & 9.84 \\
\hline \multicolumn{3}{|c|}{ If couple } & 333.40 & 109.94 & 3.03 \\
\hline \multicolumn{2}{|c|}{ Reduction in real estate value: } & Q1 & 868.96 & 363.57 & 2.39 \\
\hline -“- & Q2 & & 964.64 & 329.68 & 2.93 \\
\hline -“- & Q3 & & 1645.86 & 299.60 & 5.49 \\
\hline -“- & Q4 & & 950.99 & 285.07 & 3.34 \\
\hline \multicolumn{2}{|c|}{ Increase in real estate value } & Q1 & 822.74 & 160.89 & 5.11 \\
\hline -“- & Q2 & & 949.60 & 157.90 & 6.01 \\
\hline -“- & Q3 & & 1109.31 & 155.39 & 7.14 \\
\hline -“- & Q4 & & 1228.79 & 153.51 & 8.00 \\
\hline \multicolumn{2}{|c|}{ Reduction in financial wealth } & Q1 & -5040.23 & 450.99 & -11.18 \\
\hline -“- & Q2 & & -1262.73 & 447.12 & -2.82 \\
\hline -“- & Q3 & & 4183.65 & 444.92 & 9.40 \\
\hline -“- & Q4 & & 8891.11 & 442.78 & 20.08 \\
\hline \multicolumn{2}{|c|}{ Increase in financial wealth } & Q1 & -4805.44 & 456.48 & -10.53 \\
\hline -“- & Q2 & & -3336.77 & 449.32 & -7.43 \\
\hline -“- & Q3 & & -1394.29 & 444.97 & -3.13 \\
\hline -“- & Q4 & & 1935.80 & 440.21 & 4.40 \\
\hline \multicolumn{3}{|c|}{ Gross wealth relative to median gross wealth } & 0.0003 & 8.68e-06 & 38.29 \\
\hline \multicolumn{3}{|c|}{ Intercept } & 7577.54 & 439.41 & 17.24 \\
\hline \multicolumn{3}{|c|}{ Number of observations } & 79308 & & \\
\hline
\end{tabular}


Table 18. Deciles of the empirical distribution of capital losses (2000 SEK)

\begin{tabular}{llll}
\hline Deciles & Deciles value & Deciles & Deciles value \\
\hline 1 & 59 & 6 & 4266 \\
2 & 188 & 7 & 8519 \\
3 & 460 & 8 & 17929 \\
4 & 1060 & 9 & 42775 \\
5 & 2197 & Max & $10.6^{*} 10^{6}$ \\
\hline
\end{tabular}

Table 19. Random effects probit model for the probability of paying interest on debts, if the household did not pay interest in the previous year.

\begin{tabular}{lccc}
\hline Explanatory variables & Slope estimates & Std.err. & t-score \\
\hline Age 30-44 & 0.0372 & 0.1065 & 0.35 \\
Age 45-59 & -0.0261 & 0.1119 & -0.23 \\
Age 60-74 & -0.3885 & 0.1241 & -3.13 \\
Age 75 - & -0.4258 & 0.1317 & -3.23 \\
If only basic schooling & 0.1067 & 0.0968 & 1.10 \\
If secondary schooling & 0.2089 & 0.0794 & 2.63 \\
Debt ratio & 2.4557 & 0.2500 & 9.82 \\
If debts > assets & -1.6039 & 0.2263 & -7.09 \\
Real assets relative to median & 0.0682 & 0.0354 & 1.93 \\
Sum of all taxable labour incomes relative to median & 0.5124 & 0.0698 & 7.35 \\
Intercept & -1.4091 & 0.1229 & -11.46 \\
Sigma of household variance component u & 0.4550 & 0.0971 & \\
Fraction of residual variance due to u & 0.1715 & 0.0607 & \\
Number of observations & 2795 & & \\
Number of households & 1230 & & \\
\hline
\end{tabular}

Note 1: The debt ratio is the ratio of all household debts to gross assets if gross assets $>0$. This ratio was top coded to 1 . If gross assets $=0$ and debts $=0$ then the ratio $=0$. If gross assets $=0$ but debts $>0$ then the ratio $=1$. Note 2: Real assets were divided by the median 970805 SEK and the sum of all taxable labour incomes by the median 367624 SEK. 
Table 20. Random effects probit model for the probability of paying interest on debts, if the household paid interest in the previous year.

\begin{tabular}{lccc}
\hline Explanatory variables & Slope estimates & Std.err. & t-score \\
\hline Age 30-44 & 0.6342 & 0.1071 & 5.92 \\
Age 45-59 & 0.7635 & 0.1122 & 6.81 \\
Age 60-74 & 0.4857 & 0.1192 & 4.07 \\
Age 75 - & 0.0002 & 0.1458 & 0.00 \\
If only basic schooling & 0.0816 & 0.0928 & 0.88 \\
If secondary schooling & 0.4402 & 0.0733 & 6.00 \\
If a couple & -0.2035 & 0.0762 & -2.67 \\
Debt ratio & 5.5443 & 0.2566 & 21.60 \\
If debts > assets & -3.8855 & 0.2279 & -17.05 \\
Real assets relative to median & 0.4245 & 0.0407 & 10.42 \\
Financial assets relative to median & -0.0032 & 0.0008 & -4.12 \\
Sum of all taxable labour incomes relative to median & 0.9827 & 0.0766 & 12.82 \\
Intercept & -0.9965 & 0.1453 & -6.86 \\
Sigma of household variance component u & 1.2364 & 0.0626 & \\
Fraction of residual variance due to u & 0.6045 & 0.0242 & \\
Number of observations & 18520 & & \\
Number of households & 5329 & & \\
\hline Note: The financial assets of the household were divided by the median 146020 SEK. See also the notes of Table \\
19.
\end{tabular}


Table 21. Robust regression model for the log( interest paid on debts/ sum of debts), if the household did not pay interest in the previous year but does so in the current year.

\begin{tabular}{lccc}
\hline Explanatory variables & $\begin{array}{c}\text { Slope } \\
\text { estimates }\end{array}$ & Std.err. & t-score \\
\hline Age 30-44 & 0.4001 & 0.4078 & 0.98 \\
Age 45-59 & 0.6203 & 0.4512 & 1.37 \\
Age 60-74 & 0.9068 & 0.6302 & 1.44 \\
Age 75 - & 1.9524 & 0.8818 & 2.21 \\
If only basic schooling & 1.7520 & 0.4769 & 3.67 \\
If secondary schooling & 1.0819 & 0.3296 & 3.28 \\
Debt ratio & -1.3488 & 0.4553 & -2.96 \\
Real assets relative to median & 0.1487 & 0.1984 & 0.75 \\
Financial assets relative to median & -0.0483 & 0.0223 & -2.16 \\
Sum of tax assessed income from work relative to median & 0.3009 & 0.3151 & 0.95 \\
Change in investments in property relative to the median & 0.3075 & 0.4548 & 0.68 \\
investments in property & -5.6367 & 0.5564 & -10.13 \\
Intercept & 408 & & \\
Number of observations & & & \\
\hline
\end{tabular}

Note: Only households with a debt exceeding 1000 SEK have contributed to this regression. 
Table 22. Random effects GLS model for the log amount of interest paid on debts, if the household paid interest in the previous year and continues to do so in the current year.

\begin{tabular}{lccc}
\hline Explanatory variables & $\begin{array}{l}\text { Slope } \\
\text { estimates }\end{array}$ & Std.err. & t-score \\
\hline Age 30-44 & 0.3622 & 0.0500 & 7.25 \\
Age 45-59 & 0.3439 & 0.0514 & 6.68 \\
Age 60-74 & 0.4021 & 0.0567 & 7.08 \\
Age 75 - & 0.4276 & 0.0844 & 5.07 \\
Debt ratio & -0.5122 & 0.0470 & -10.89 \\
If debts > assets & -0.1043 & 0.0372 & -2.81 \\
Real assets relative to median & -0.0406 & 0.0082 & -4.97 \\
Change in investments in property relative to the median & -0.1239 & 0.0136 & -9.09 \\
investments in property & 0.3666 & 0.0075 & 49.03 \\
Log(debt rate) t-1 & -1.8714 & 0.0604 & -30.98 \\
Intercept & 0.5807 & & \\
Sigma of household variance component u & 0.5530 & & \\
Sigma of white noise variance component & 0.5244 & & \\
Fraction of residual variance due to u & 11954 & & \\
Number of observations & 4247 & & \\
Number of households & & & \\
\hline
\end{tabular}


Table 23. Indices of wealth growth and financial markets $(1999=100)$

\begin{tabular}{lllllll}
\hline Year & CPI & $\begin{array}{l}\text { Long } \\
\text { bonds }\end{array}$ & $\begin{array}{l}\text { Stock } \\
\text { market }\end{array}$ & $\begin{array}{l}\text { Market } \\
\text { value of } \\
\text { single } \\
\text { family }\end{array}$ & $\begin{array}{l}\text { Mean net } \\
\text { wealth in }\end{array}$ & $\begin{array}{l}\text { Median net } \\
\text { wealth in }\end{array}$ \\
& & & & & & \\
& & & & & & \\
& & & & & & \\
1999 & 100 & 100.0 & 100.0 & 100.0 & 100.0 & 100.0 \\
2000 & 101.0 & 105.1 & 95.6 & 111.0 & 107.2 & 152.0 \\
2010 & 120.4 & 164.1 & 121.0 & 177.0 & 165.1 & 518.2 \\
2020 & 146.7 & 267.3 & 174.9 & 249.6 & 221.7 & 798.3 \\
2030 & 178.9 & 435.4 & 252.7 & 352.1 & 254.4 & 954.2 \\
2040 & 218.0 & 709.2 & 365.1 & 496.8 & 267.8 & 1048.9 \\
Average & $1.9 \%$ & $4.9 \%$ & $3.2 \%$ & $3.9 \%$ & $2.4 \%$ & $5.7 \%$ \\
annual & & & & & & \\
growth & & & & & & \\
\hline
\end{tabular}


Table 24. Disposable income in 1999 year prices before and after retirement for different birth cohorts, income levels and retirement ages.

\begin{tabular}{|c|c|c|c|c|c|c|c|}
\hline \multirow[t]{2}{*}{ Cohort } & \multirow[t]{2}{*}{$\begin{array}{c}\text { Income } \\
\text { class }\end{array}$} & \multicolumn{2}{|c|}{$\begin{array}{l}\text { Age of Retirement } \\
65\end{array}$} & \multicolumn{2}{|c|}{$\begin{array}{l}\text { Age of Retirement } \\
67\end{array}$} & \multicolumn{2}{|c|}{$\begin{array}{l}\text { Age of Retirement } \\
63\end{array}$} \\
\hline & & $\begin{array}{c}\text { Age } \\
65-69 \\
(1) \\
\end{array}$ & $\begin{array}{c}\text { Age } \\
70-74 \\
(2) \\
\end{array}$ & $\begin{array}{c}\text { Age } \\
67-71 \\
(3) \\
\end{array}$ & $\begin{array}{c}\text { Age } \\
72-76 \\
(4) \\
\end{array}$ & $\begin{array}{c}\text { Age } \\
63-67 \\
(5)\end{array}$ & $\begin{array}{c}\text { Age } \\
68-72 \\
(6) \\
\end{array}$ \\
\hline \multirow{3}{*}{1937} & $<$ p25 & 129 & 143 & 127 & 128 & 140 & 150 \\
\hline & p25-p75 & 97 & 97 & 102 & 98 & 86 & 92 \\
\hline & $>$ p75 & 74 & 71 & 77 & 72 & 59 & 61 \\
\hline \multirow{3}{*}{1940} & $<$ p25 & 110 & 113 & 113 & 116 & 104 & 107 \\
\hline & p25-p75 & 89 & 83 & 93 & 90 & 87 & 85 \\
\hline & $>$ p75 & 78 & 71 & 79 & 72 & 68 & 63 \\
\hline \multirow{3}{*}{1943} & $<$ p25 & 110 & 111 & 115 & 113 & 102 & 107 \\
\hline & p25-p75 & 86 & 80 & 97 & 88 & 84 & 83 \\
\hline & $>$ p75 & 65 & 62 & 74 & 66 & 69 & 64 \\
\hline \multirow{3}{*}{1946} & $<$ p25 & 102 & 104 & 121 & 121 & 101 & 105 \\
\hline & p25-p75 & 87 & 81 & 98 & 92 & 81 & 78 \\
\hline & $>$ p75 & 73 & 62 & 75 & 69 & 69 & 60 \\
\hline \multirow{3}{*}{1949} & $<\mathrm{p} 25$ & 110 & 109 & 117 & 109 & 105 & 106 \\
\hline & p25-p75 & 85 & 79 & 91 & 85 & 83 & 80 \\
\hline & $>$ p75 & 72 & 60 & 72 & 64 & 68 & 59 \\
\hline \multirow{3}{*}{1952} & $<\mathrm{p} 25$ & 107 & 100 & 111 & 109 & 100 & 107 \\
\hline & p25-p75 & 83 & 76 & 92 & 85 & 80 & 75 \\
\hline & $>$ p75 & 68 & 61 & 71 & 61 & 64 & 57 \\
\hline \multirow{3}{*}{1955} & $<$ p25 & 108 & 102 & 113 & 104 & 103 & 101 \\
\hline & p25-p75 & 83 & 73 & 92 & 81 & 79 & 74 \\
\hline & $>$ p75 & 64 & 54 & 73 & 62 & 67 & 57 \\
\hline
\end{tabular}

Note: SESIM generated $1999-2041$. All individuals have worked at least five years preceding the retirement and survived at least until 10 years thereafter. Inflation $\approx 2 \% /$ year, real wage $\approx 2 \% /$ year and long interest rate $5 \% /$ year. 
Table 25. Disposable income before and after retirement for different birth cohorts in 1999 year prices.

\begin{tabular}{|c|c|c|c|c|c|}
\hline \multirow[t]{2}{*}{ Cohort } & \multirow[t]{2}{*}{$\begin{array}{l}\text { Income } \\
\text { class }\end{array}$} & \multicolumn{2}{|c|}{$\begin{array}{c}\text { High return } \\
7 \%\end{array}$} & \multicolumn{2}{|c|}{$\begin{array}{c}\text { Low return } \\
3 \%\end{array}$} \\
\hline & & $\begin{array}{c}\text { Age } \\
\text { 65-69 } \\
(1)\end{array}$ & $\begin{array}{c}\text { Age } \\
70-74 \\
(2) \\
\end{array}$ & $\begin{array}{c}\text { Age } \\
65-69 \\
(3)\end{array}$ & $\begin{array}{c}\text { Age } \\
70-74 \\
(4) \\
\end{array}$ \\
\hline \multirow{3}{*}{1937} & $<\mathrm{p} 25$ & 118 & 120 & 118 & 120 \\
\hline & p25-p75 & 95 & 94 & 97 & 95 \\
\hline & $>$ p75 & 73 & 64 & 73 & 63 \\
\hline \multirow{3}{*}{1940} & $<\mathrm{p} 25$ & 105 & 100 & 104 & 99 \\
\hline & p25-p75 & 87 & 76 & 88 & 78 \\
\hline & $>$ p75 & 77 & 63 & 77 & 63 \\
\hline \multirow{3}{*}{1943} & $<\mathrm{p} 25$ & 98 & 95 & 98 & 95 \\
\hline & p25-p75 & 82 & 73 & 83 & 74 \\
\hline & $>$ p75 & 68 & 59 & 67 & 58 \\
\hline \multirow{3}{*}{1946} & $<\mathrm{p} 25$ & 103 & 95 & 101 & 93 \\
\hline & p25-p75 & 83 & 75 & 81 & 71 \\
\hline & $>$ p75 & 70 & 58 & 70 & 59 \\
\hline \multirow{3}{*}{1949} & $<\mathrm{p} 25$ & 105 & 95 & 100 & 95 \\
\hline & p25-p75 & 86 & 73 & 81 & 71 \\
\hline & $>$ p75 & 73 & 60 & 70 & 58 \\
\hline \multirow{3}{*}{1952} & $<\mathrm{p} 25$ & 101 & 90 & 94 & 83 \\
\hline & p25-p75 & 85 & 72 & 76 & 68 \\
\hline & $>$ p75 & 71 & 61 & 66 & 54 \\
\hline \multirow{3}{*}{1955} & $<\mathrm{p} 25$ & 108 & 97 & 92 & 83 \\
\hline & p25-p75 & 86 & 75 & 78 & 67 \\
\hline & $>$ p75 & 70 & 55 & 67 & 52 \\
\hline
\end{tabular}

Note: SESIM generated 1999 - 2041. All individuals have worked at least five years preceding the retirement at 65 and survived at least until 75 . Inflation $\approx 2 \% /$ year, real wage $\approx 2 \% /$ year and long interest rate $5 \% /$ year. 
Table 26. Replacement rates for different birth cohorts and income levels.

Average income in age 65-69 and 70-74 related to average taxable income in age 60-64.

\begin{tabular}{|c|c|c|c|c|c|c|c|c|c|}
\hline \multirow{2}{*}{ Cohort } & \multirow{2}{*}{$\begin{array}{l}\text { Income } \\
\text { class }\end{array}$} & \multicolumn{4}{|c|}{ Age $65-69$} & \multicolumn{4}{|c|}{ Age $70-74$} \\
\hline & & $\begin{array}{l}\text { Taxable } \\
\text { Income } \\
\%\end{array}$ & $\begin{array}{l}\text { Public } \\
\text { Pension } \\
\%\end{array}$ & $\begin{array}{l}\text { Occupat } \\
\text {-ional } \\
\text { Pension } \\
\% \\
\end{array}$ & $\begin{array}{l}\text { Private } \\
\text { Pension } \\
\%\end{array}$ & $\begin{array}{l}\text { Taxable } \\
\text { Income } \\
\%\end{array}$ & $\begin{array}{l}\text { Public } \\
\text { Pension } \\
\%\end{array}$ & $\begin{array}{l}\text { Occupat } \\
\text {-ional } \\
\text { Pension } \\
\% \\
\end{array}$ & $\begin{array}{l}\text { Private } \\
\text { Pension } \\
\%\end{array}$ \\
\hline \multirow{3}{*}{1937} & $<$ p25 & 112 & 88 & 8 & 14 & 105 & 92 & 7 & 3 \\
\hline & p25-p75 & 79 & 60 & 7 & 9 & 74 & 63 & 7 & 2 \\
\hline & $>$ p75 & 67 & 43 & 14 & 8 & 64 & 46 & 13 & 3 \\
\hline \multirow{3}{*}{1940} & $<$ p25 & 97 & 73 & 8 & 13 & 88 & 75 & 7 & 1 \\
\hline & p25-p75 & 77 & 56 & 10 & 10 & 69 & 58 & 8 & 1 \\
\hline & $>$ p75 & 67 & 37 & 18 & 10 & 57 & 39 & 15 & 2 \\
\hline \multirow{3}{*}{1943} & $<$ p25 & 91 & 69 & 10 & 10 & 84 & 71 & 9 & 2 \\
\hline & p25-p75 & 78 & 54 & 13 & 10 & 68 & 55 & 9 & 1 \\
\hline & $>$ p75 & 66 & 36 & 19 & 10 & 55 & 37 & 14 & 3 \\
\hline \multirow{3}{*}{1946} & $<$ p25 & 89 & 64 & 13 & 10 & 79 & 66 & 10 & 2 \\
\hline & p25-p75 & 75 & 51 & 14 & 10 & 65 & 52 & 10 & 2 \\
\hline & $>$ p75 & 64 & 33 & 21 & 9 & 52 & 34 & 15 & 2 \\
\hline \multirow{3}{*}{1949} & $<$ p25 & 94 & 66 & 14 & 13 & 80 & 67 & 10 & 2 \\
\hline & p25-p75 & 73 & 48 & 15 & 9 & 63 & 49 & 10 & 1 \\
\hline & $>$ p75 & 63 & 33 & 20 & 9 & 51 & 34 & 14 & 2 \\
\hline \multirow{3}{*}{1952} & $<$ p25 & 88 & 61 & 15 & 11 & 76 & 62 & 11 & 1 \\
\hline & p25-p75 & 72 & 47 & 16 & 7 & 61 & 48 & 11 & 1 \\
\hline & $>$ p75 & 60 & 31 & 21 & 7 & 47 & 31 & 13 & 1 \\
\hline \multirow{3}{*}{1955} & $<$ p25 & 89 & 62 & 16 & 9 & 77 & 63 & 11 & 1 \\
\hline & p25-p75 & 74 & 49 & 16 & 8 & 62 & 49 & 11 & 0 \\
\hline & $>$ p75 & 62 & 31 & 22 & 8 & 46 & 31 & 13 & 1 \\
\hline
\end{tabular}

Note: SESIM generated 1999 - 2041. All individuals have worked at least five years preceding the retirement at 65 and survived at least until 75 . Inflation $\approx 2 \% /$ year, real wage $\approx 2 \% /$ year and long interest rate $5 \% /$ year. 
Table 27. Sensitivity analyses of replacement rates for the cohort born 1950. Average income age 65-69 in relation to income prior to 65.

\begin{tabular}{|c|c|c|c|c|c|}
\hline & \multicolumn{5}{|c|}{ Different definitions of income before retirement at age 65} \\
\hline $\begin{array}{l}\text { Selections and } \\
\text { definitions of income } \\
\text { before } 65\end{array}$ & $\begin{array}{l}\text { Average } \\
\text { earnings } \\
\text { for } \\
\text { age 60-64 } \\
\text { (1) }\end{array}$ & $\begin{array}{l}\text { Average } \\
\text { earnings } \\
\text { for } \\
\text { age 55-64 } \\
\text { (2) }\end{array}$ & $\begin{array}{l}\text { Average } \\
\text { earnings } \\
\text { for } \\
\text { age 49-64 } \\
\text { (3) }\end{array}$ & $\begin{array}{l}\text { Earnings at } \\
\text { age } 55\end{array}$ & $\begin{array}{l}\text { Earnings at } \\
\text { age } 64\end{array}$ \\
\hline $\mathrm{All}^{1}$ & 61 & 58 & 57 & 55 & 66 \\
\hline Worked before 65 & 45 & 46 & 48 & 48 & 45 \\
\hline $\begin{array}{l}\text { Worked before } 65 \text { and } \\
\text { adjusted earnings } \\
\text { equation }\end{array}$ & 50 & 48 & 49 & 48 & 56 \\
\hline $\begin{array}{l}\text { At least } 30 \text { years of } \\
\text { pension rights and only } \\
\text { income below the } \\
\text { ceiling. }\end{array}$ & 66 & 64 & 64 & 62 & 71 \\
\hline
\end{tabular}

We assume that all individuals have retired at 65 ; inflation $\approx 2 \% /$ year, real wage rate $\approx 2 \% /$ year, nominal return on financial assets $5 \% / y e a r$.

Table 28. An evaluation of the NSIO replacement rate.

Income for the cohort born 1950 at age 65 in relation to income before 65.

\begin{tabular}{|c|c|}
\hline $\begin{array}{l}\text { Selections and definitions of income before } \\
65 .\end{array}$ & $\begin{array}{l}\text { Public pension } \\
\%\end{array}$ \\
\hline $\begin{array}{l}\text { Working 60-64. } \\
\text { Average income 60-64. }\end{array}$ & 44 \\
\hline $\begin{array}{l}\text { Number of year with pension rights } \geq 30 \text {. } \\
\text { Average income } 49-64 \text {. }\end{array}$ & 57 \\
\hline $\begin{array}{l}\text { Same as above and: } \\
\text { Only income }<8.07 \text { income base amount. }\end{array}$ & $63^{3}$ \\
\hline
\end{tabular}


Table 29. Taxable income of pensioners relative to taxable income of everyone aged 2064, by birth cohort, age and relative income quartile of the pensioners.

\begin{tabular}{|l|rrr|rrr|rrr|}
\hline & \multicolumn{3}{|c|}{ Cohort 1937 } & \multicolumn{3}{|c|}{ Cohort 1946 } & \multicolumn{3}{c|}{ Cohort 1955 } \\
\cline { 5 - 10 } age & $<\mathrm{q} 25$ & $\mathrm{q} 25-\mathrm{q} 75$ & $>\mathrm{q} 75$ & $<\mathrm{q} 25$ & $\mathrm{q} 25-\mathrm{q} 75$ & $>\mathrm{q} 75$ & $<\mathrm{q} 25$ & $\mathrm{q} 25-\mathrm{q} 75$ & $>\mathrm{q} 75$ \\
65 & 0,52 & 0,71 & 0,93 & 0,55 & 0,73 & 0,94 & 0,54 & 0,71 & 0,89 \\
69 & 0,50 & 0,69 & 0,89 & 0,52 & 0,67 & 0,87 & 0,50 & 0,66 & 0,83 \\
70 & 0,48 & 0,64 & 0,80 & 0,46 & 0,57 & 0,71 & 0,43 & 0,55 & 0,68 \\
75 & 0,46 & 0,61 & 0,75 & 0,43 & 0,53 & 0,65 & 0,41 & 0,51 & 0,62 \\
80 & 0,43 & 0,56 & 0,70 & 0,40 & 0,50 & 0,60 & 0,38 & 0,47 & 0,57 \\
85 & 0,40 & 0,53 & 0,66 & 0,38 & 0,47 & 0,56 & 0,36 & 0,43 & 0,53 \\
90 & 0,37 & 0,50 & 0,61 & 0,35 & 0,43 & 0,54 & 0,33 & 0,41 & 0,49 \\
\hline
\end{tabular}

Table 30. Gini coefficients by birth cohort and age

\begin{tabular}{|l|llll|}
\hline age & Cohort & & & \\
$455-49$ & 1937 & 1943 & 1949 & 1955 \\
$50-54$ & & & & 0,23 \\
$55-59$ & & & 0,26 & 0,27 \\
$60-64$ & 0,32 & 0,29 & 0,34 & 0,38 \\
$65-69$ & 0,23 & 0,28 & 0,35 & 0,31 \\
$70-74$ & 0,31 & 0,30 & 0,34 & 0,32 \\
$75-79$ & 0,35 & 0,29 & 0,28 & 0,30 \\
$80-84$ & 0,36 & 0,32 & 0,31 & 0,28 \\
$85-89$ & 0,30 & 0,27 & 0,30 & 0,29 \\
\hline
\end{tabular}




\section{Figures}

Figure 1. The income distribution of households aged 55-90 in a few selected OECD countries. (In PPP converted US dollars)

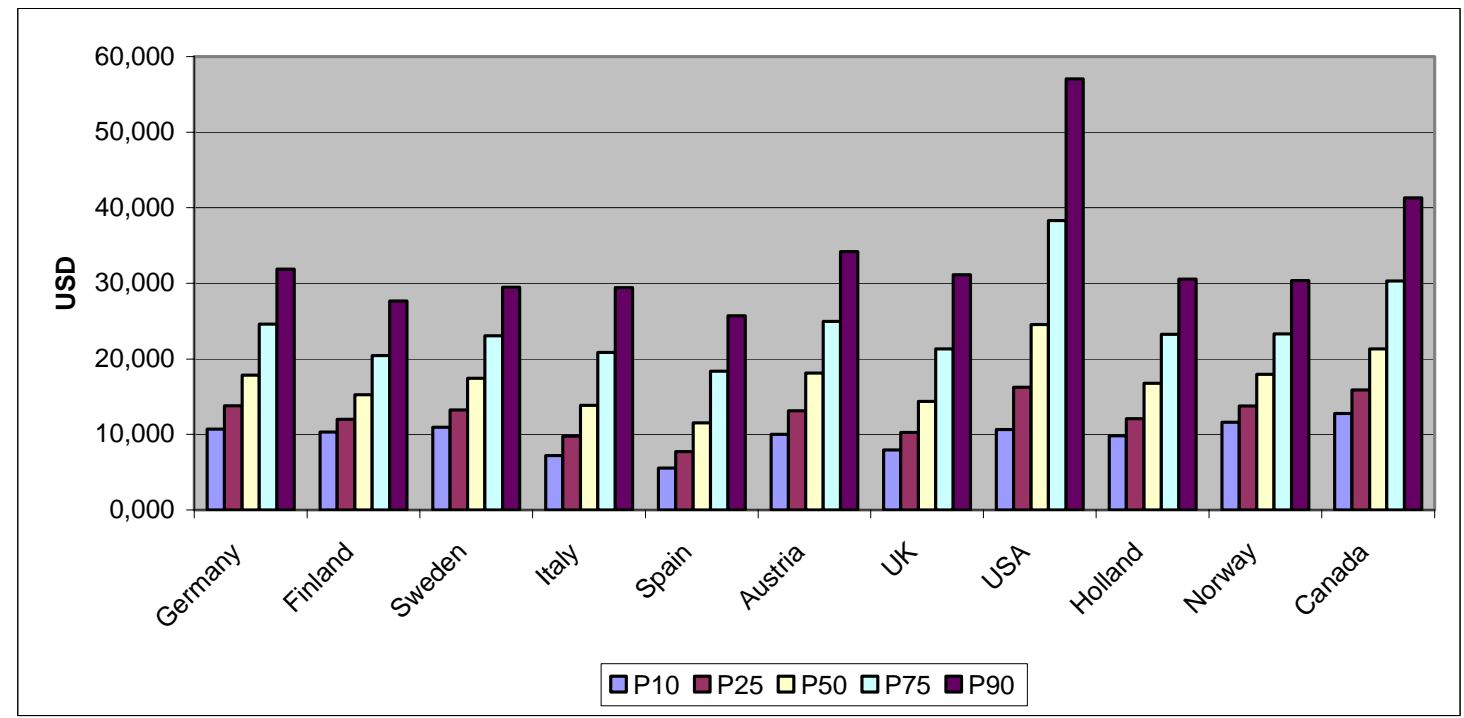

Source: Luxemburg Income Studies (LIS)

Note: Net income divided by square root of family members in households age 55-90.

The income year is 1999 for the UK and Holland and 2000 for all others.

P10 income at first decile, P25 at first quartile, P50 at median, P75 at third quartile and P90 at upper decile.

Figure 2. The income distribution of households aged 65-90 in a few selected OECD countries. (In PPP converted US dollars)

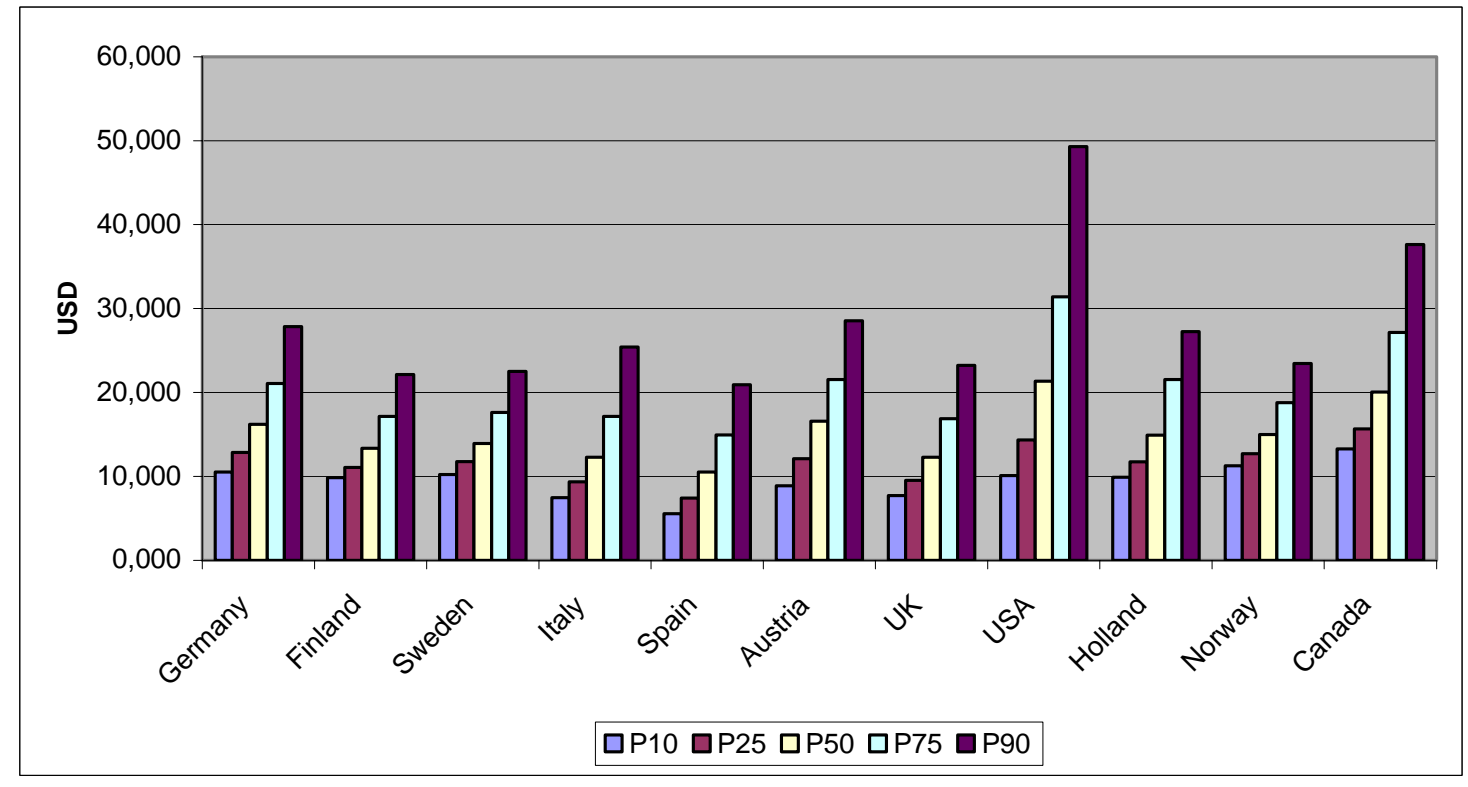

Source: Luxemburg Income Studies (LIS)

Note: Net income divided by square root of family members in households age 65-90.

The income year is 1999 for the UK and Holland and 2000 for all others.

P10 income at first decile, P25 at first quartile, P50 at median, P75 at third quartile and P90 at upper decile. 
Figure 3. Equalised disposable income 1975-2003 (means per family unit in thousands of SEK, 2003 price level)

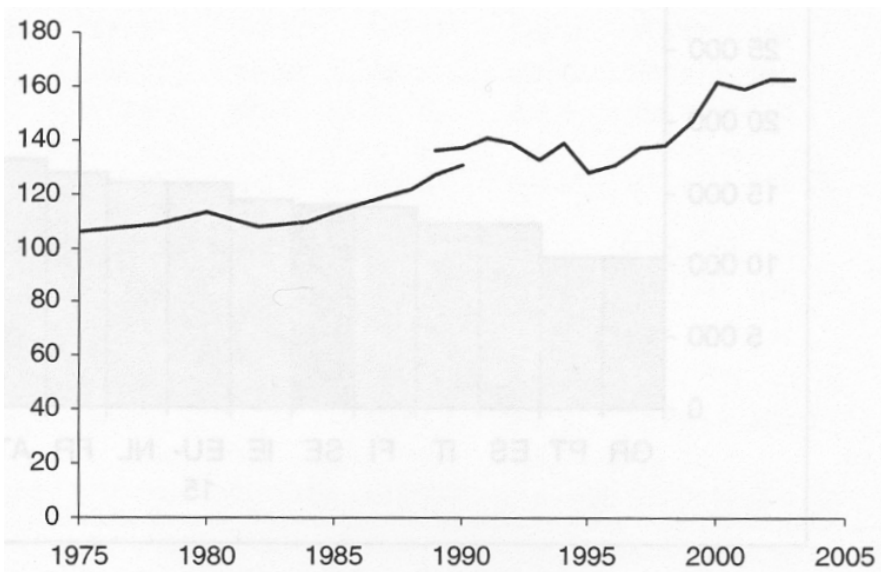

Source: Income distribution survey 2003, Statistiska Meddelanden HE 21 SM 0501 p. 11 Note: Disposable income includes realized capital gains

Figure 4. Gini coefficients for equalized disposable income per family unit

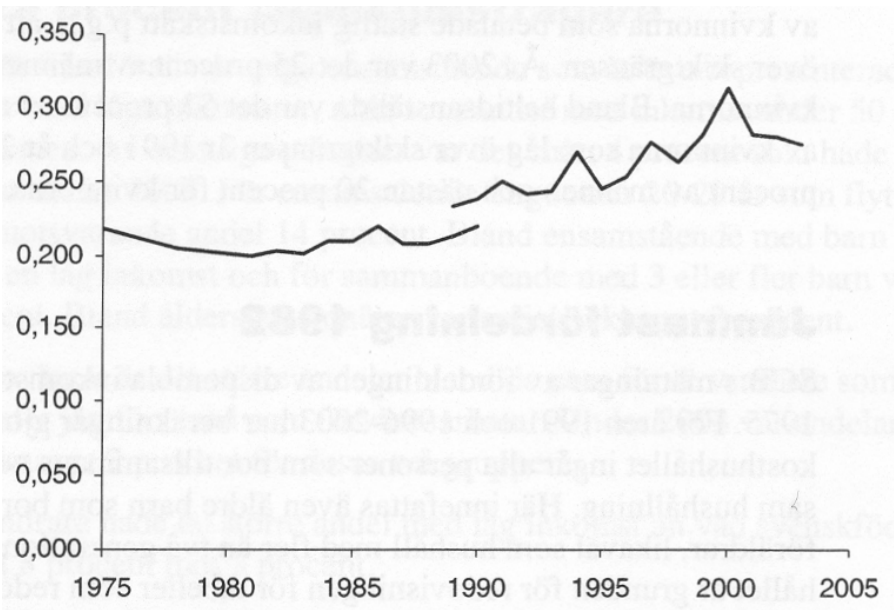

Source: Income distribution survey 2003, Statistiska Meddelanden HE 21 SM 0501 p. 12 Note: Disposable income includes realized capital gains 
Figure 5a. Male Labour force participation rates

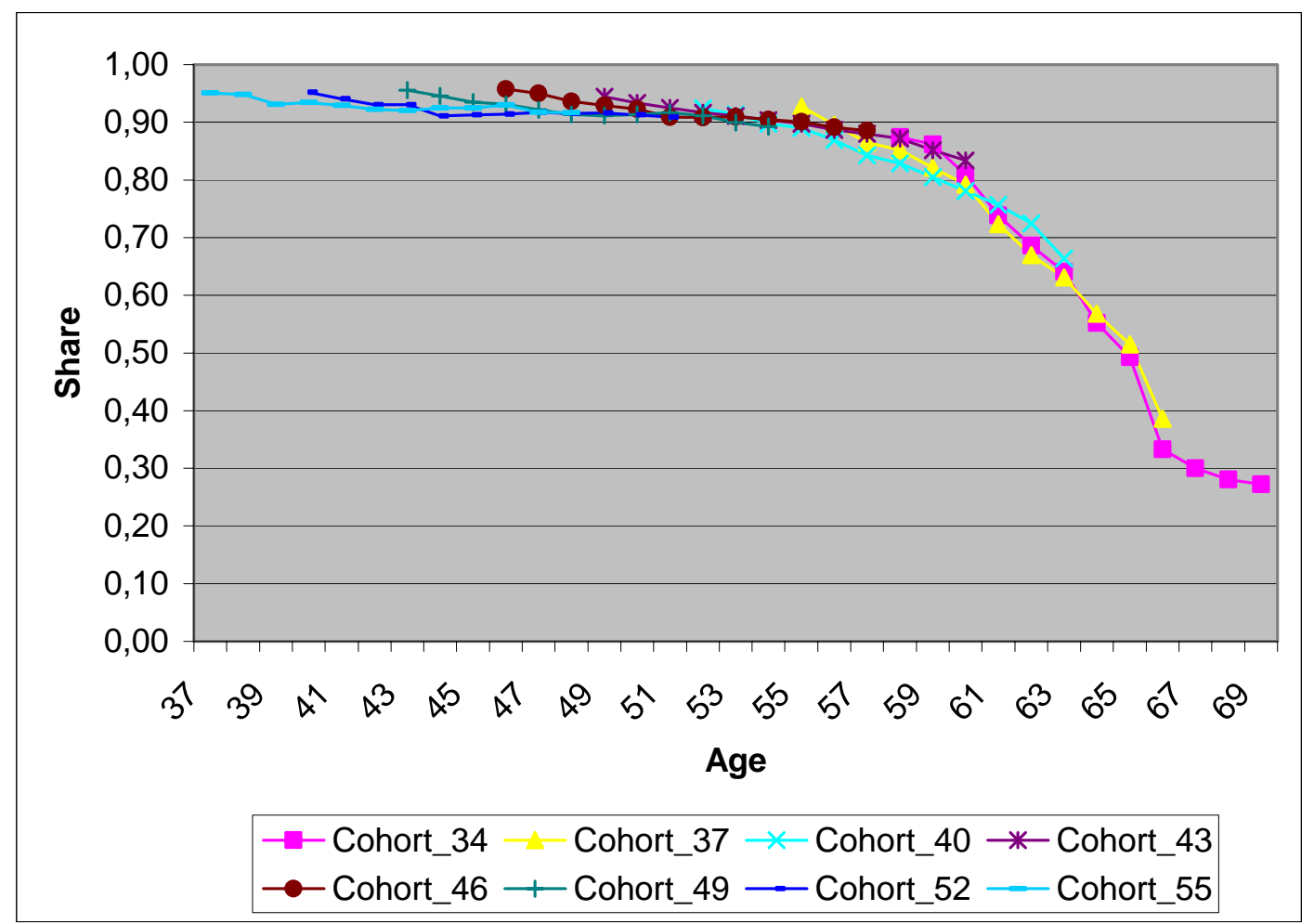

Source: Linda data 1992-2003

Figure 5b. Female Labour force participation rates

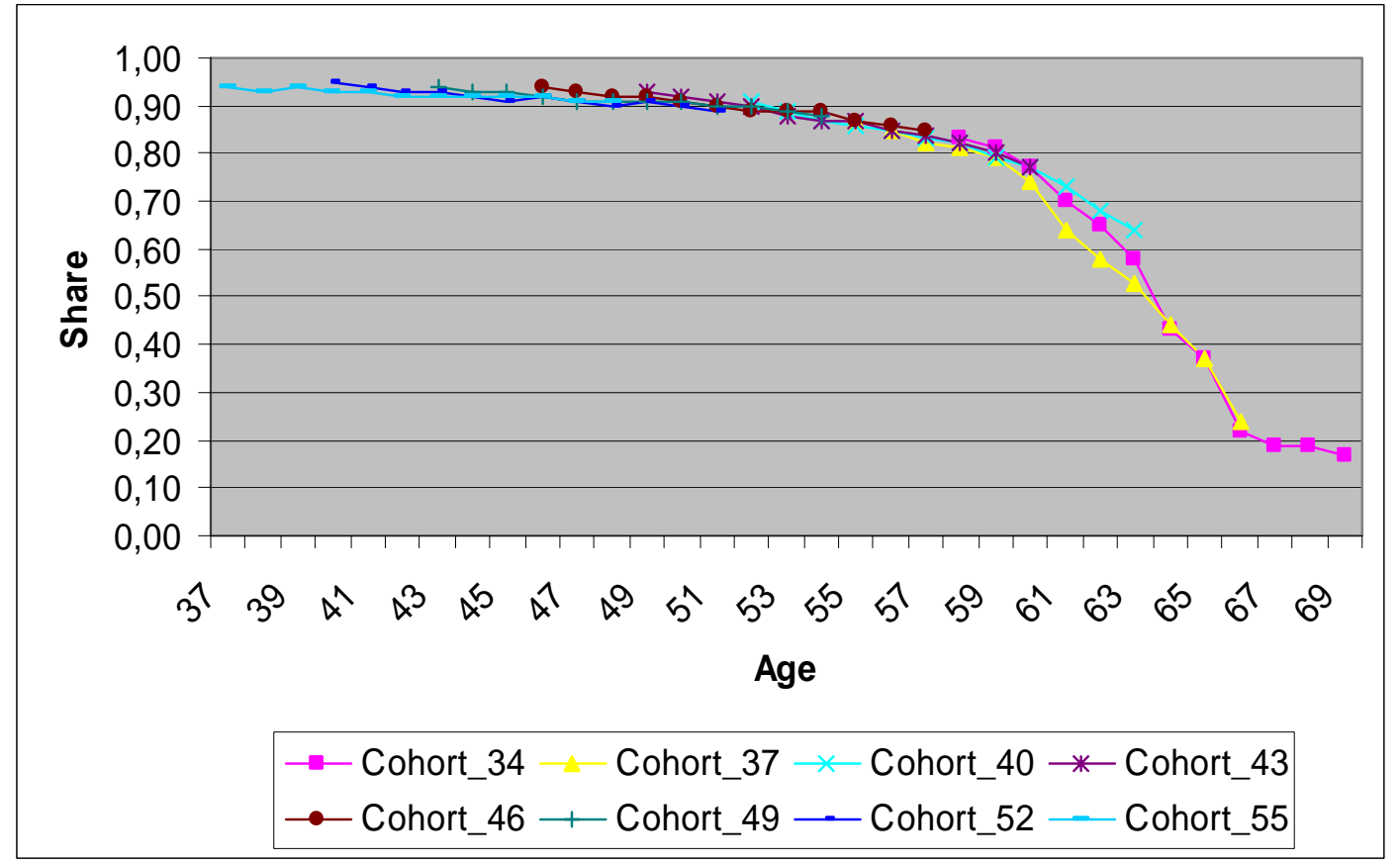

Source: Linda data 1992-2003 
Figure 6a. Male income from employment and business in year 2000 prices

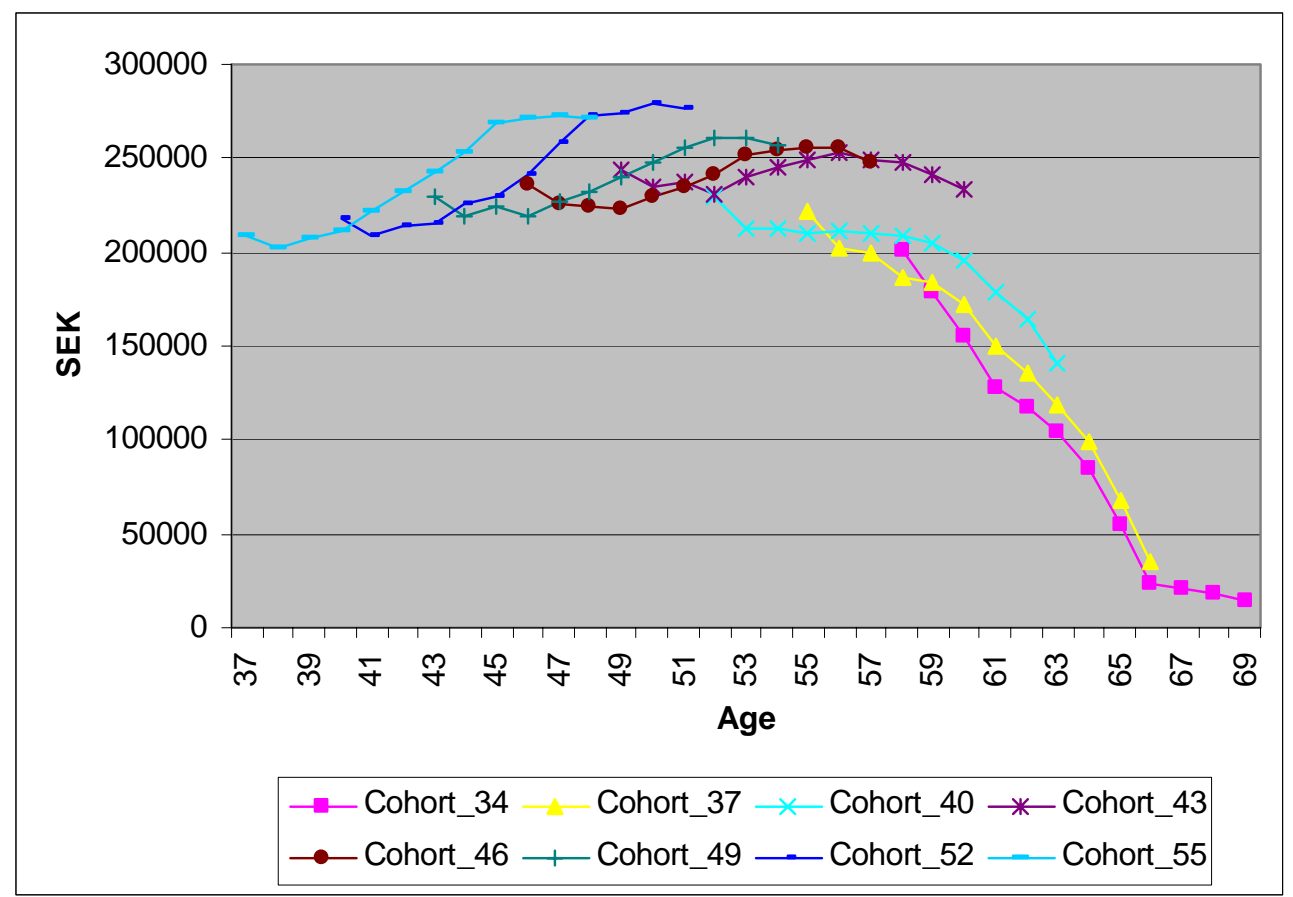

Source: Linda data 1992-2003

Figure 6b. Female income from employment and business in year 2000 prices

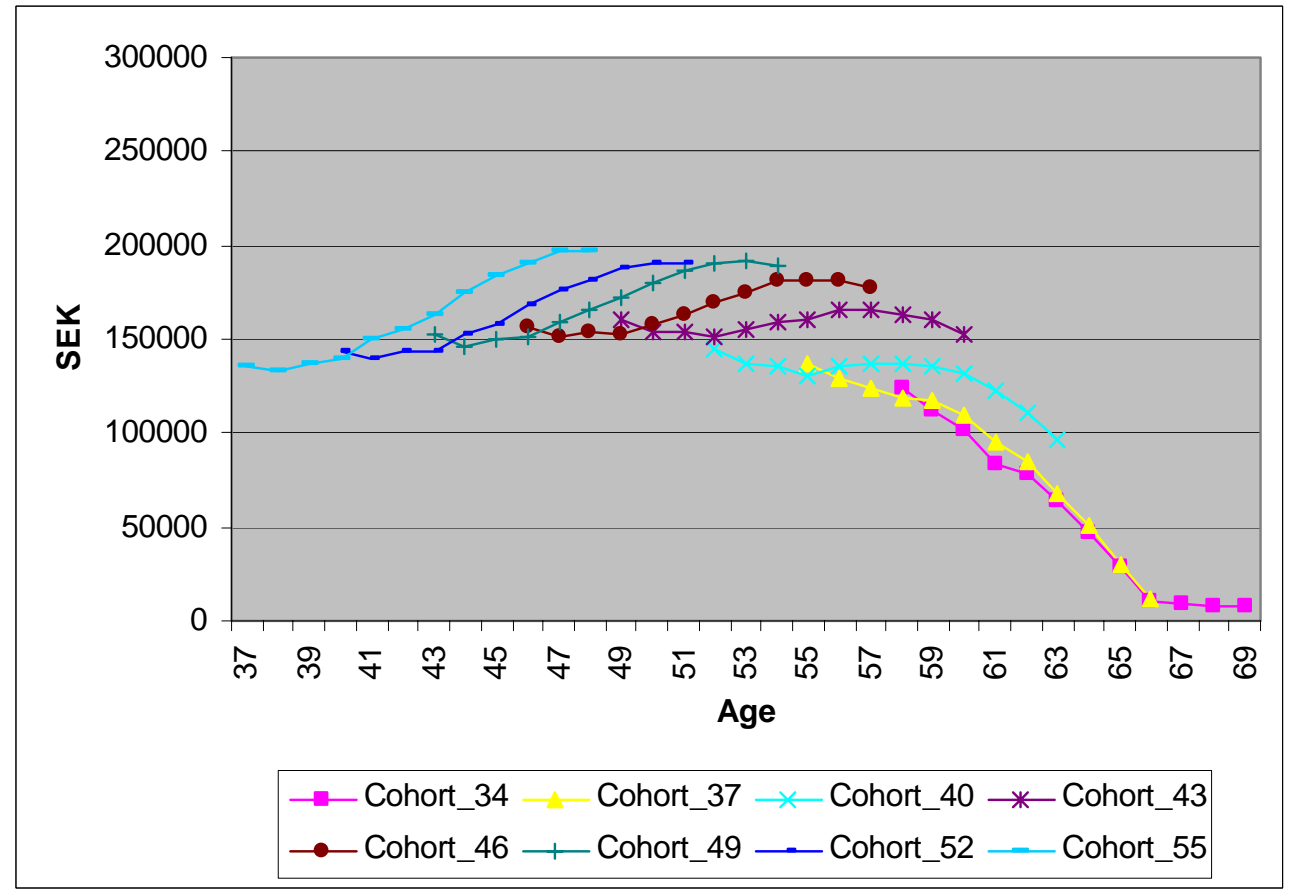

Source: Linda data 1992-2003 
Figure 7a. Male income from employment and business given positive value in year 2000 prices

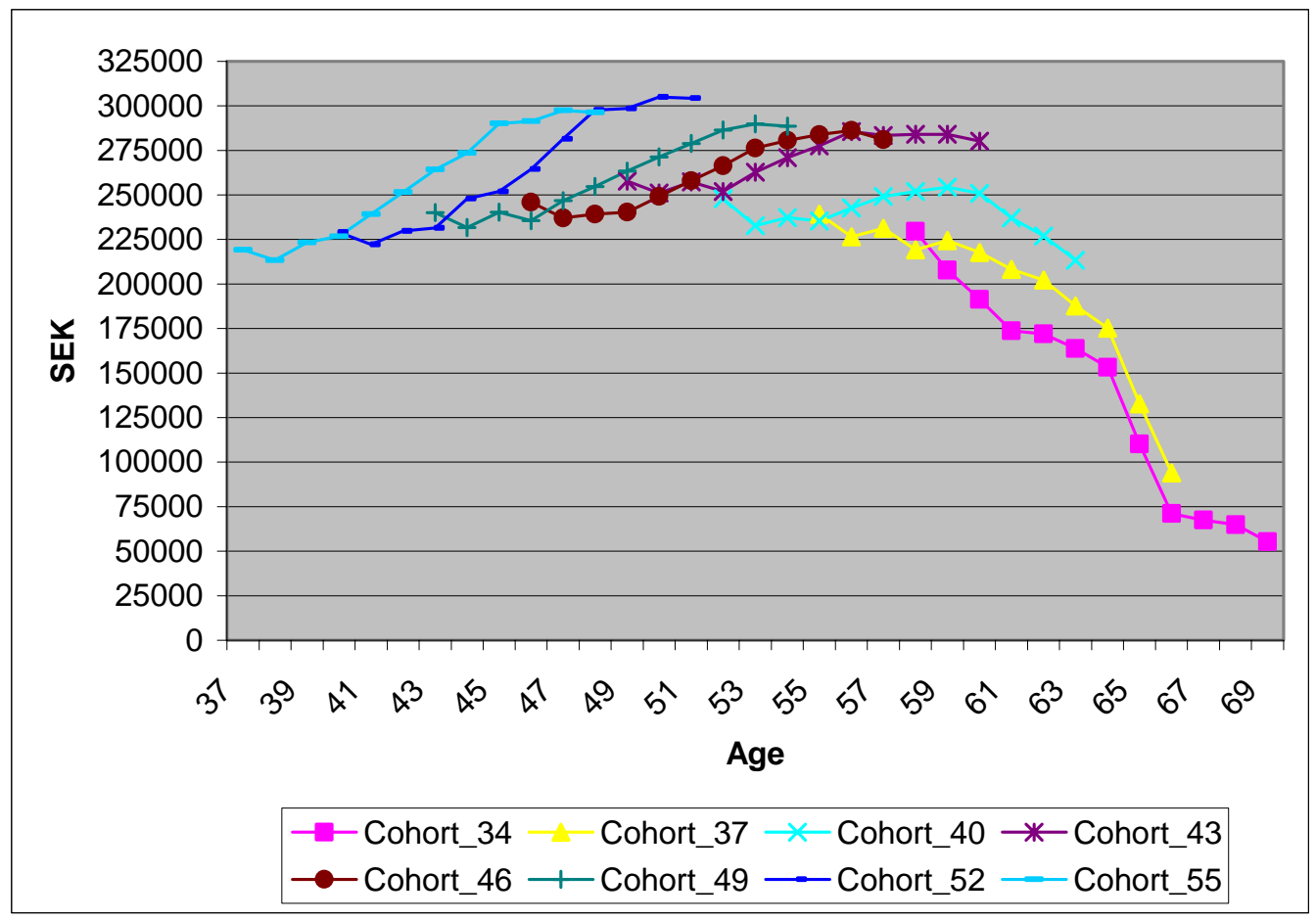

Source: Linda data 1992-2003

Figure $7 \mathrm{~b}$. Female income from employment and business given positive value in year 2000 prices

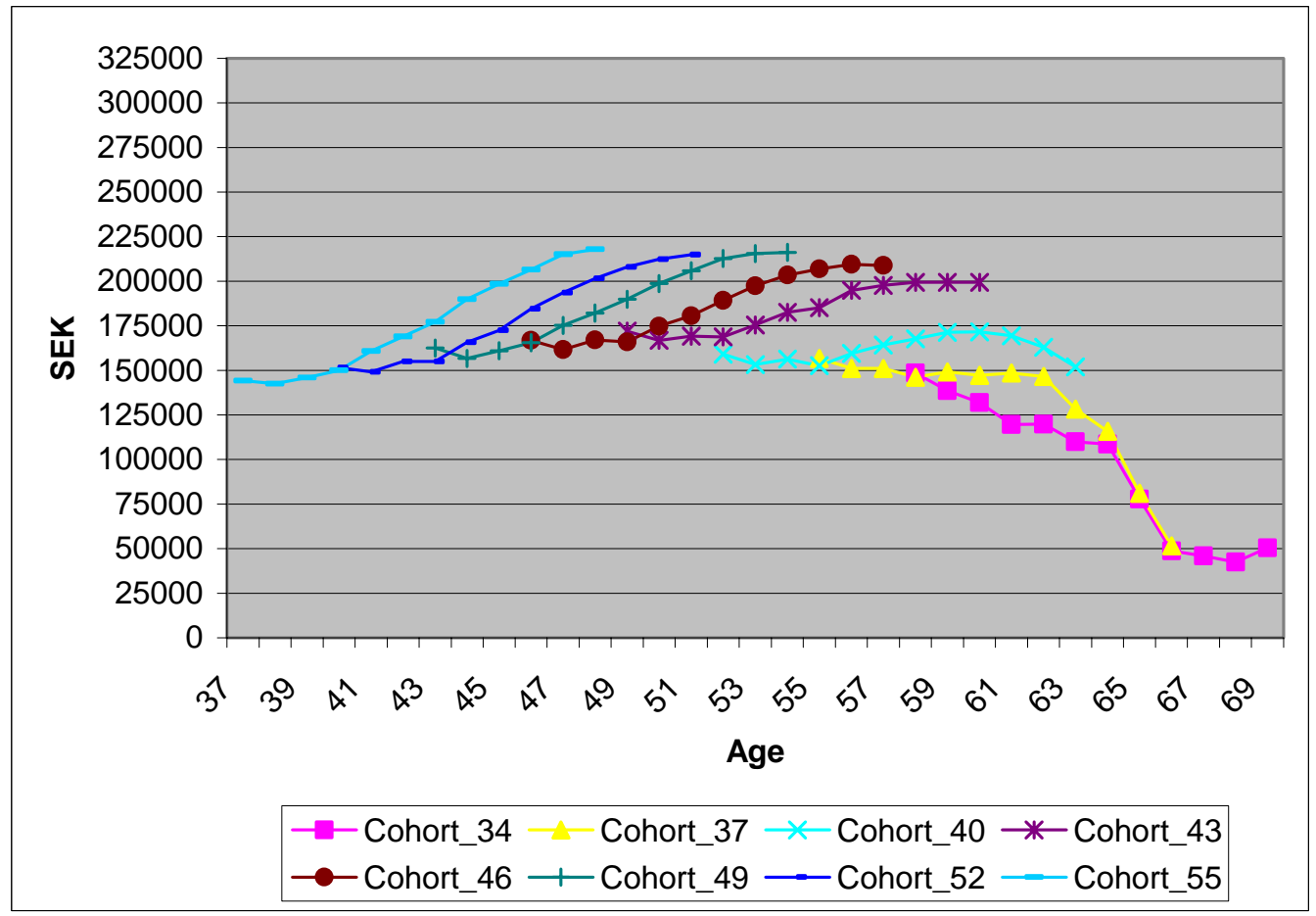

Source: Linda data 1992-2003 
Figure 8a. Male incomes from pensions in year 2000 prices

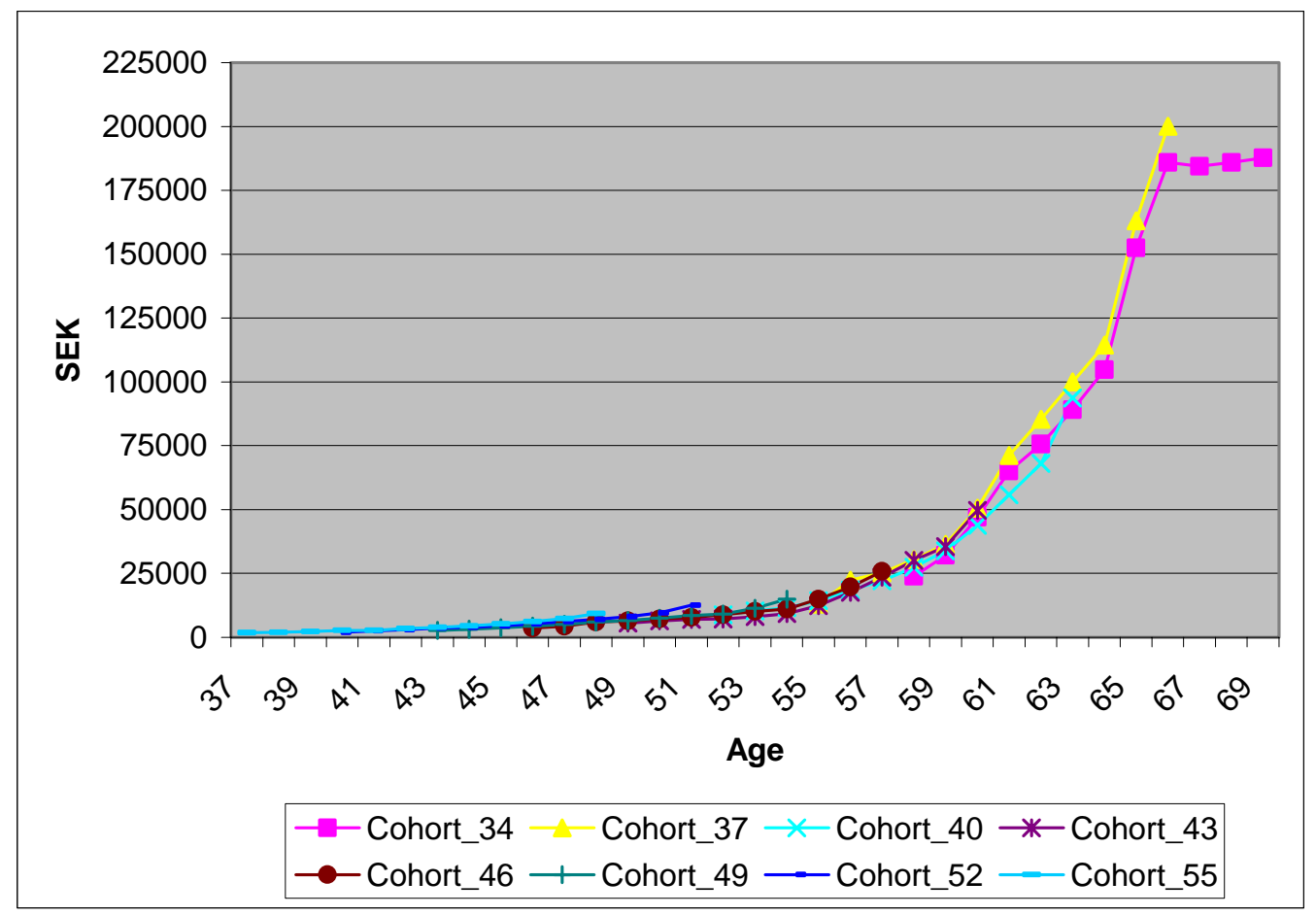

Source: Linda data 1992-2003

Figure 8b. Female incomes from pensions in year 2000 prices

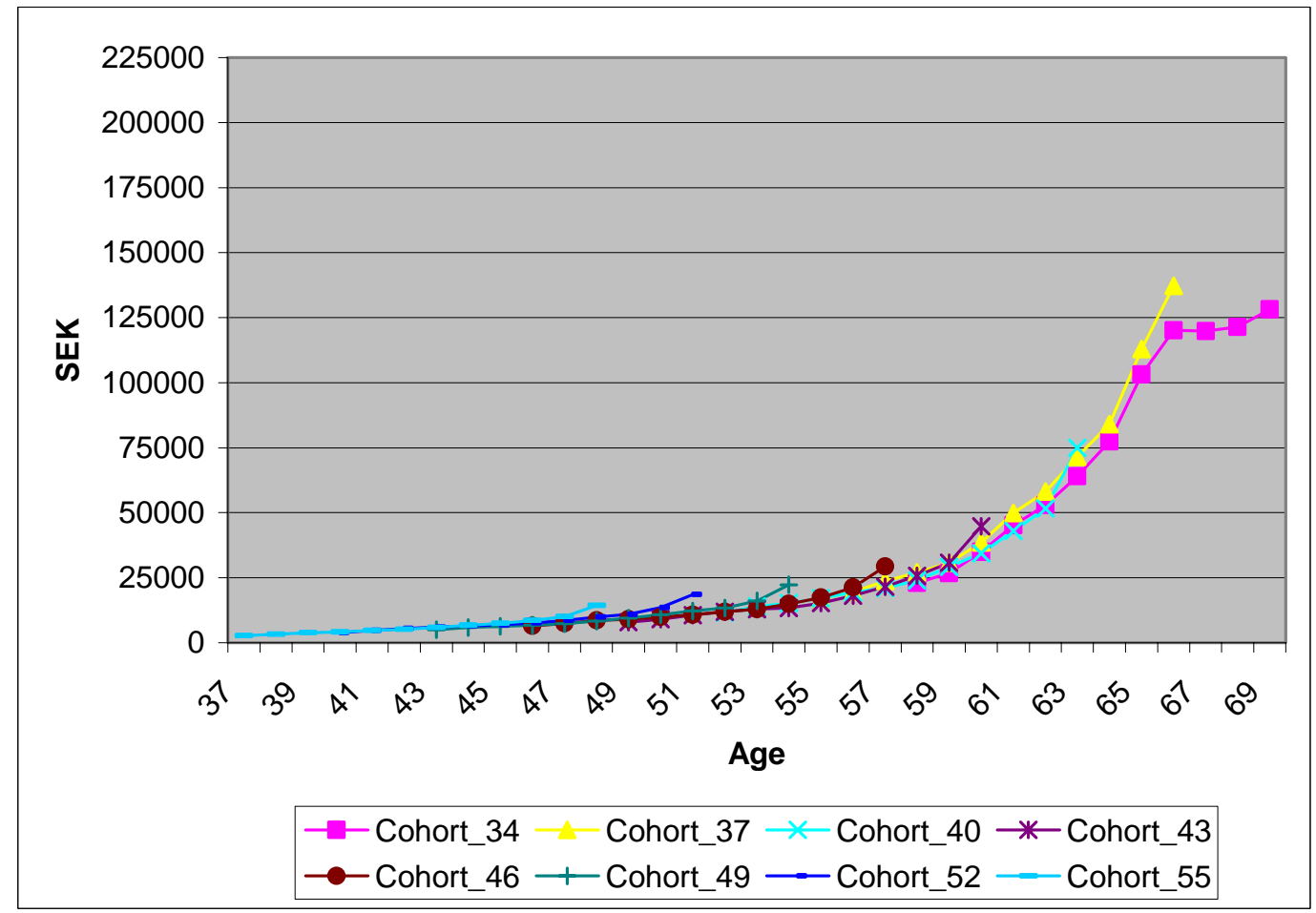

Source: Linda data 1992-2003 
Figure 9a. Male income from capital in year 2000 prices

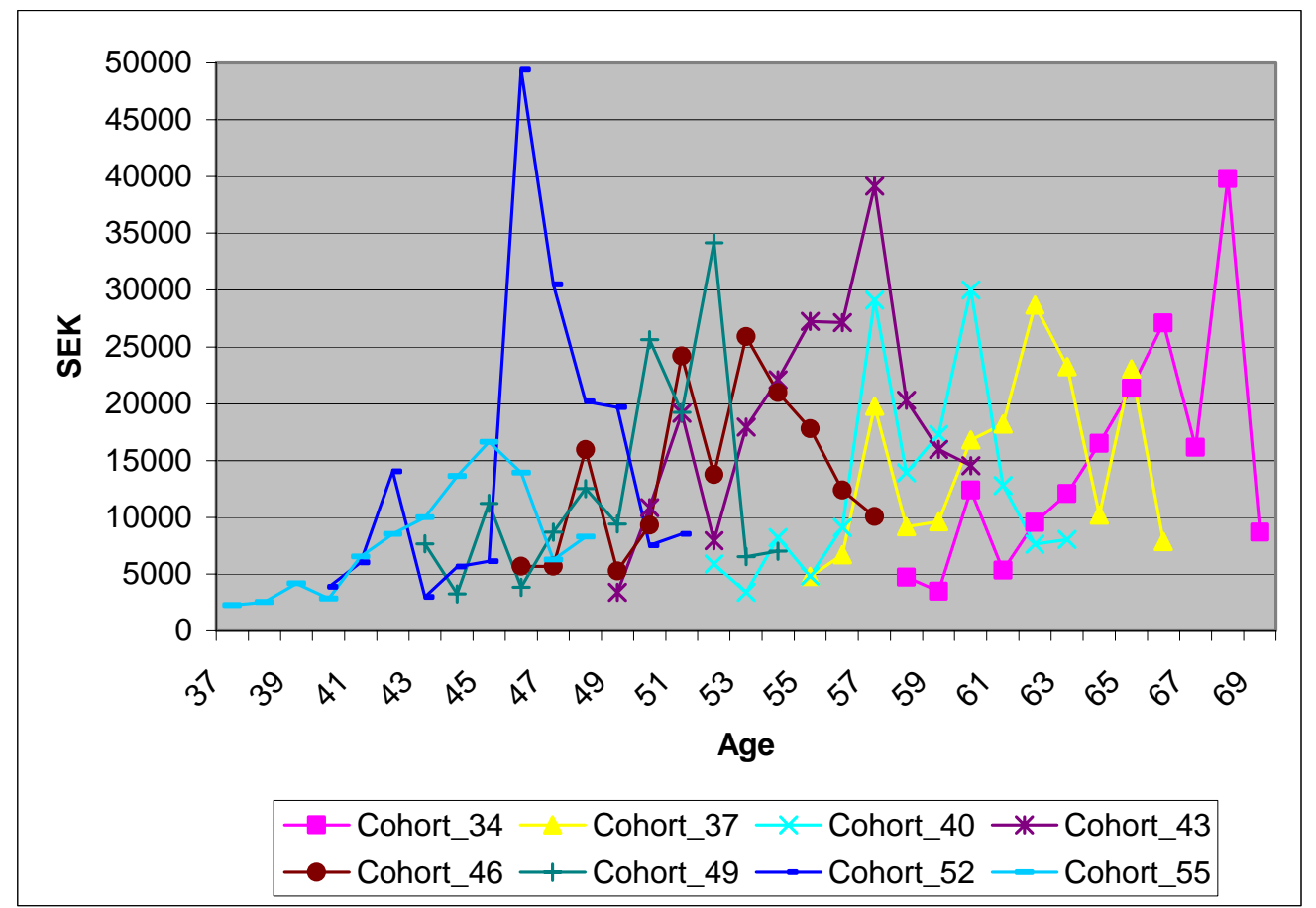

Source: Linda data 1992-2003

Figure 9b. Female income from capital in year 2000 prices

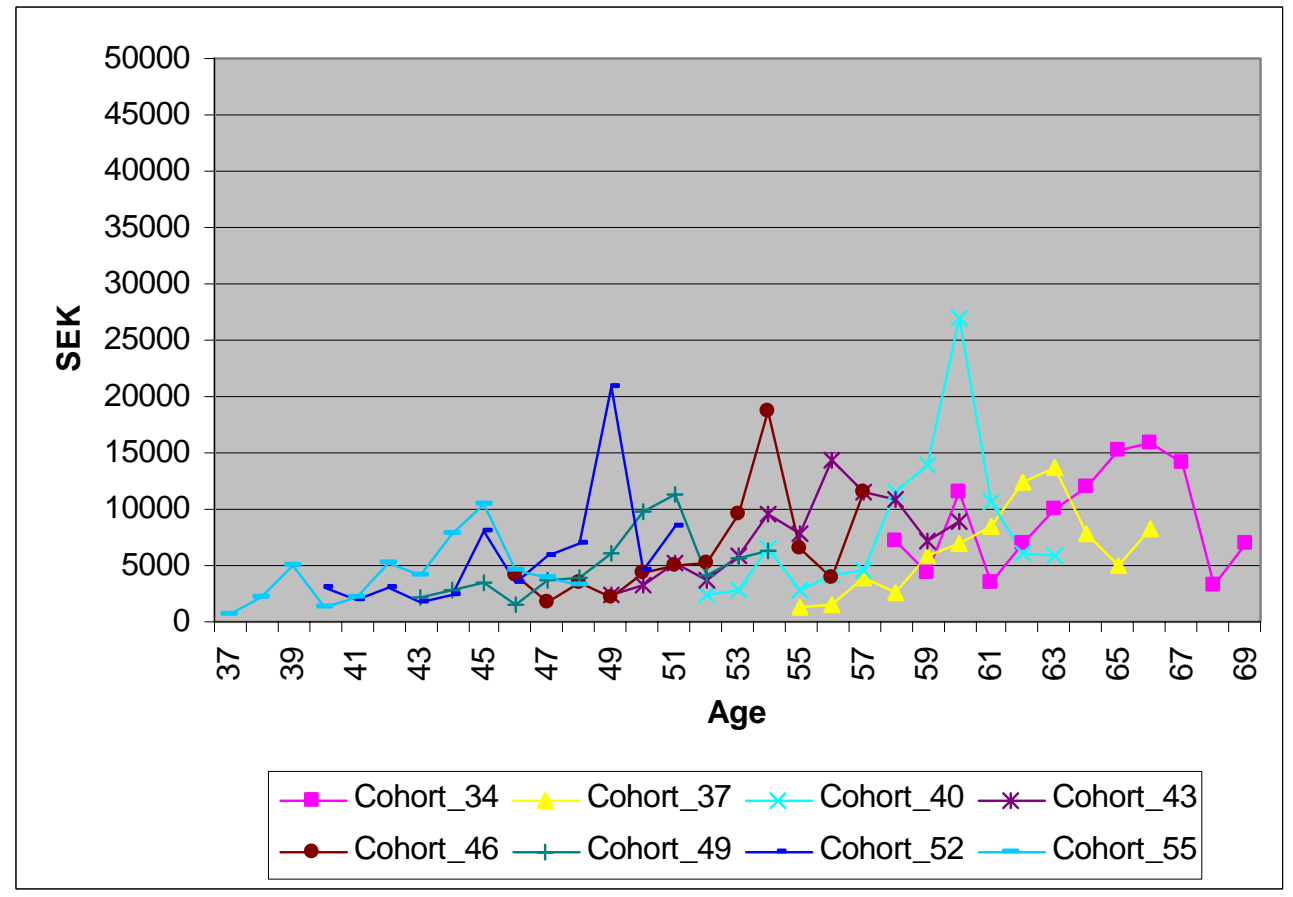

Source: Linda data 1992-2003 
Figure 10. The Stockholm exchange general index 1987-2003

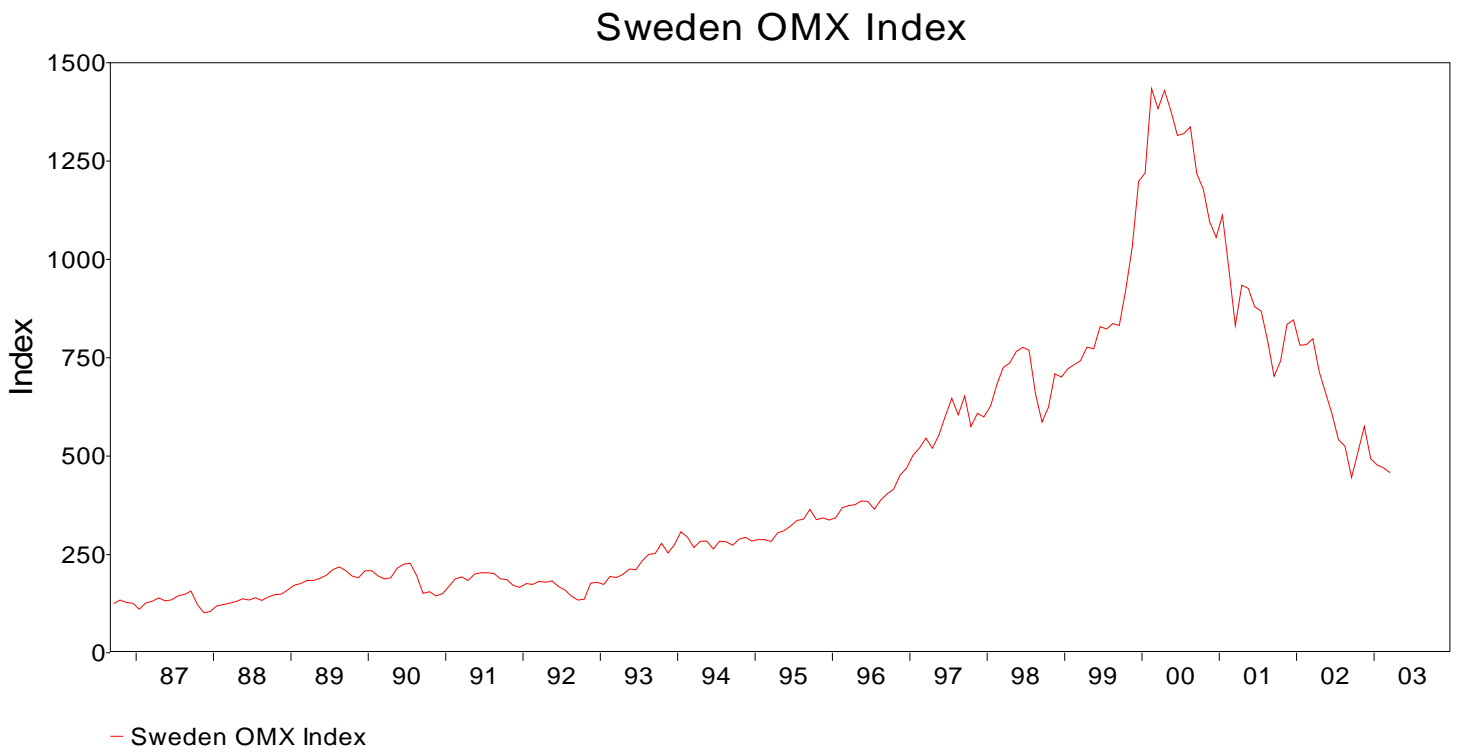

Source: EcoWin

Figure 11. Equalised disposable income (means per family unit in year 2000 prices)

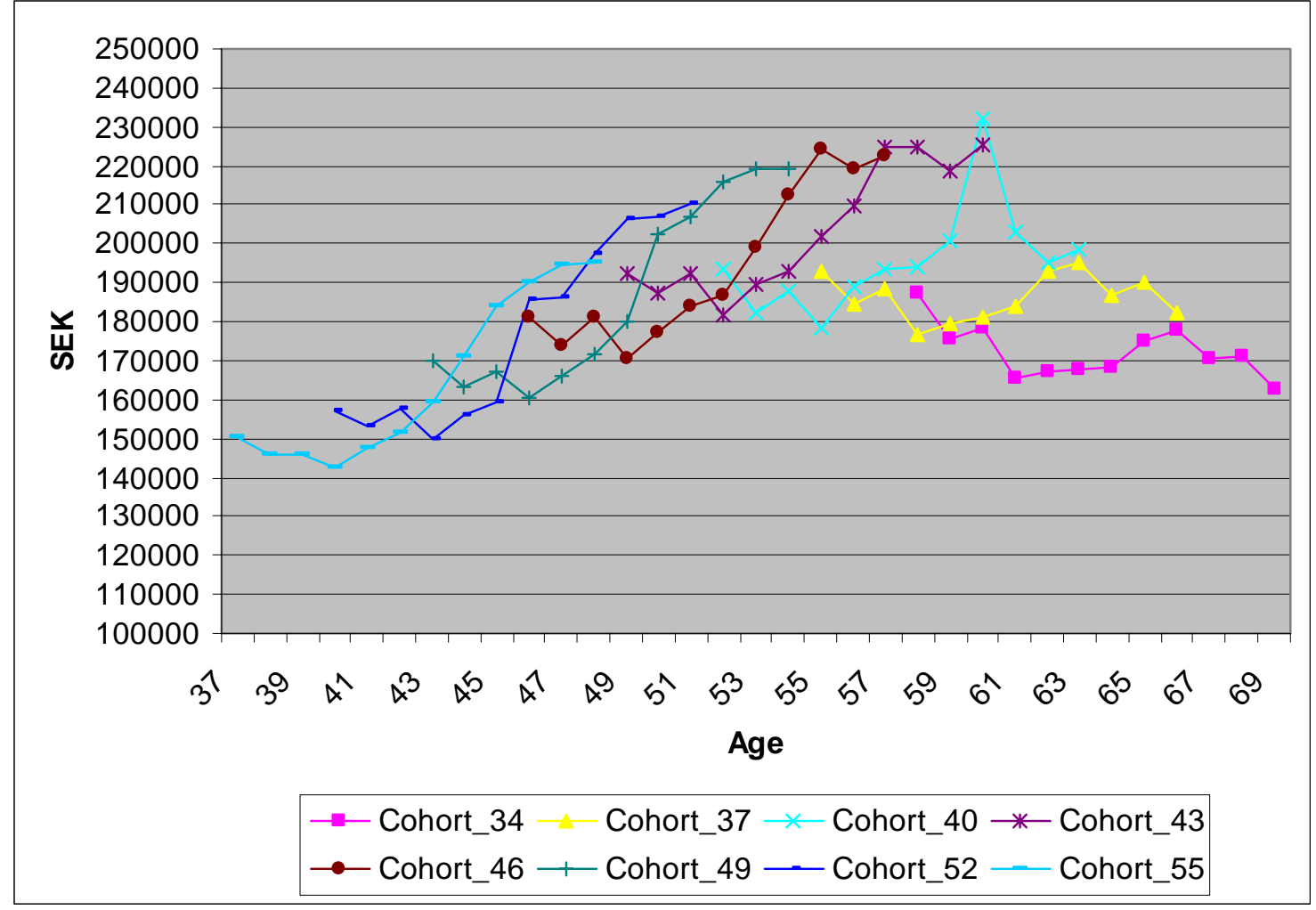

Source: Linda data 1992-2003 
Figure 12. Structure of SESIM

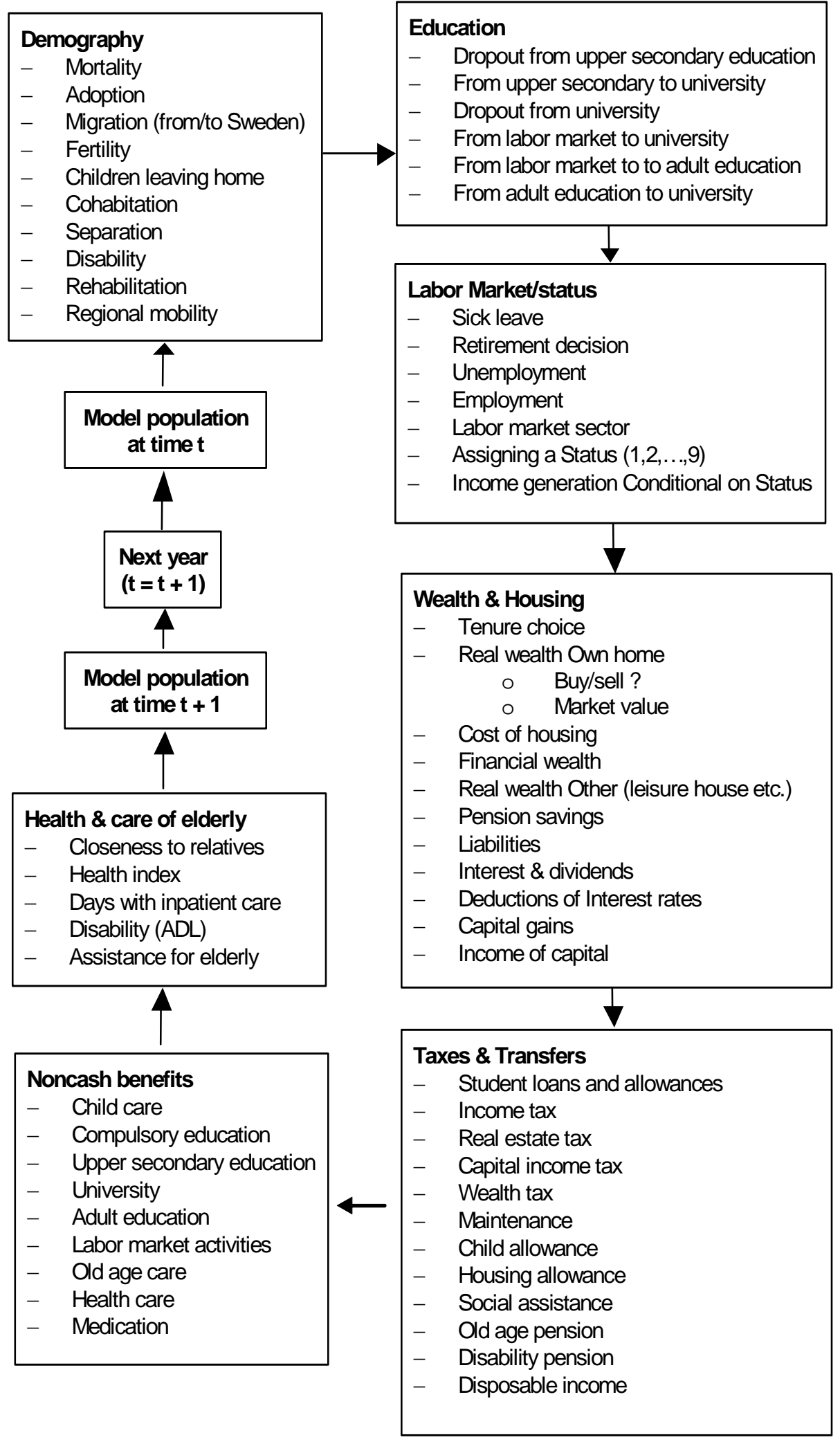




\section{Figure 13 Real and Financial wealth and cost of housing in SESIM}

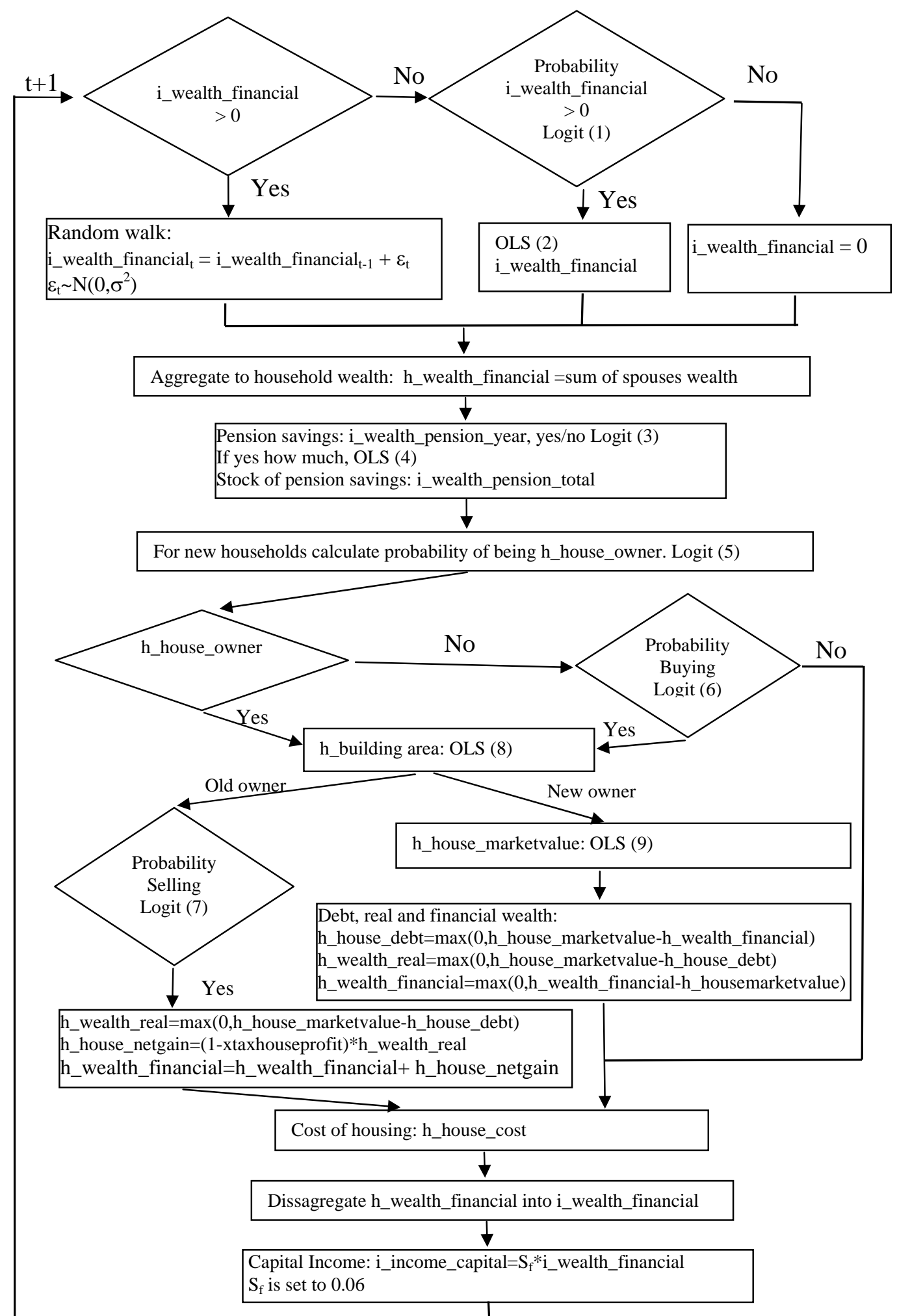


Figure 14. Taxable income for different samples of the cohort born 1950

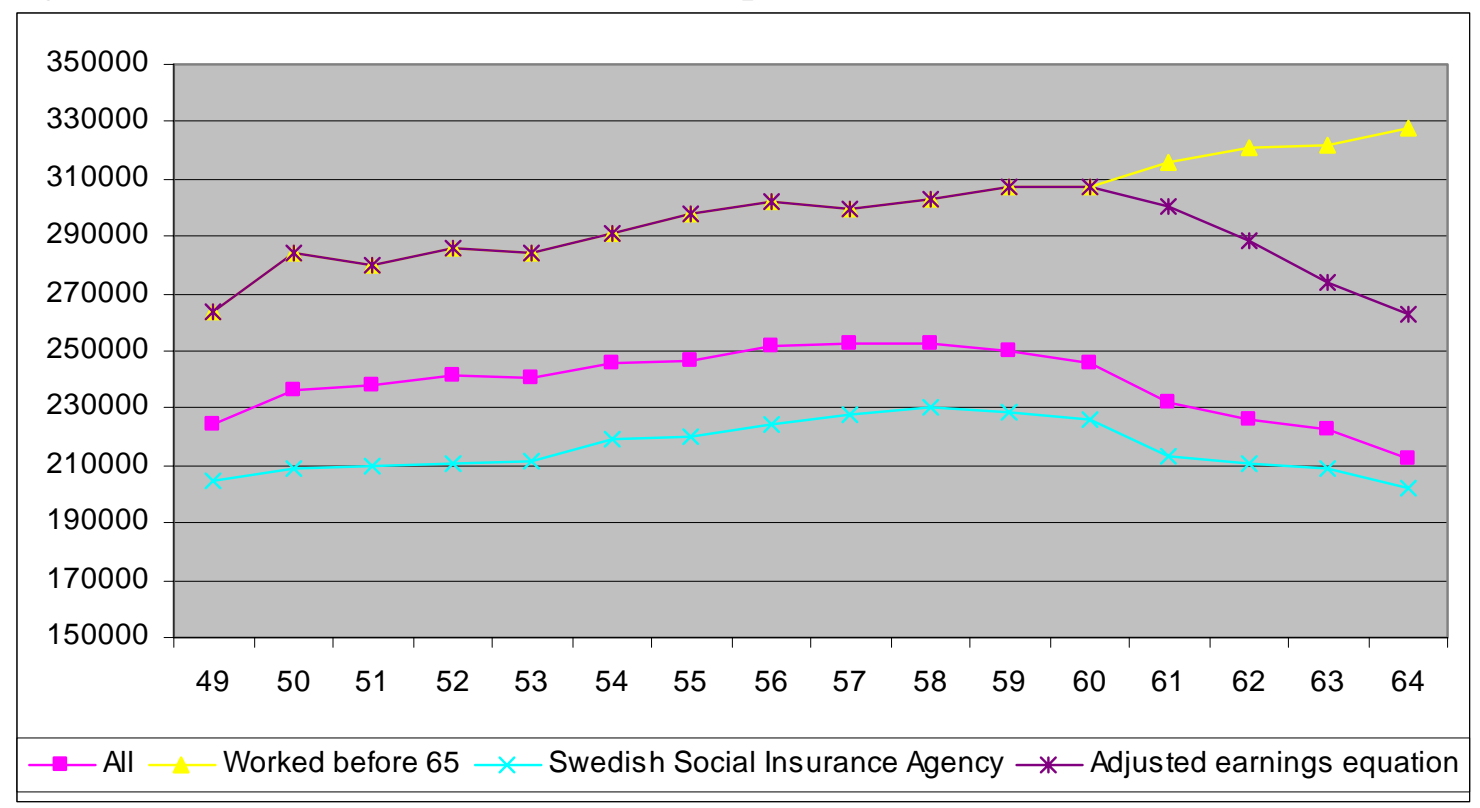

Figure 15. Average taxable incomes for pensioners relative to the average taxable income of the working cohorts (age 20-64).

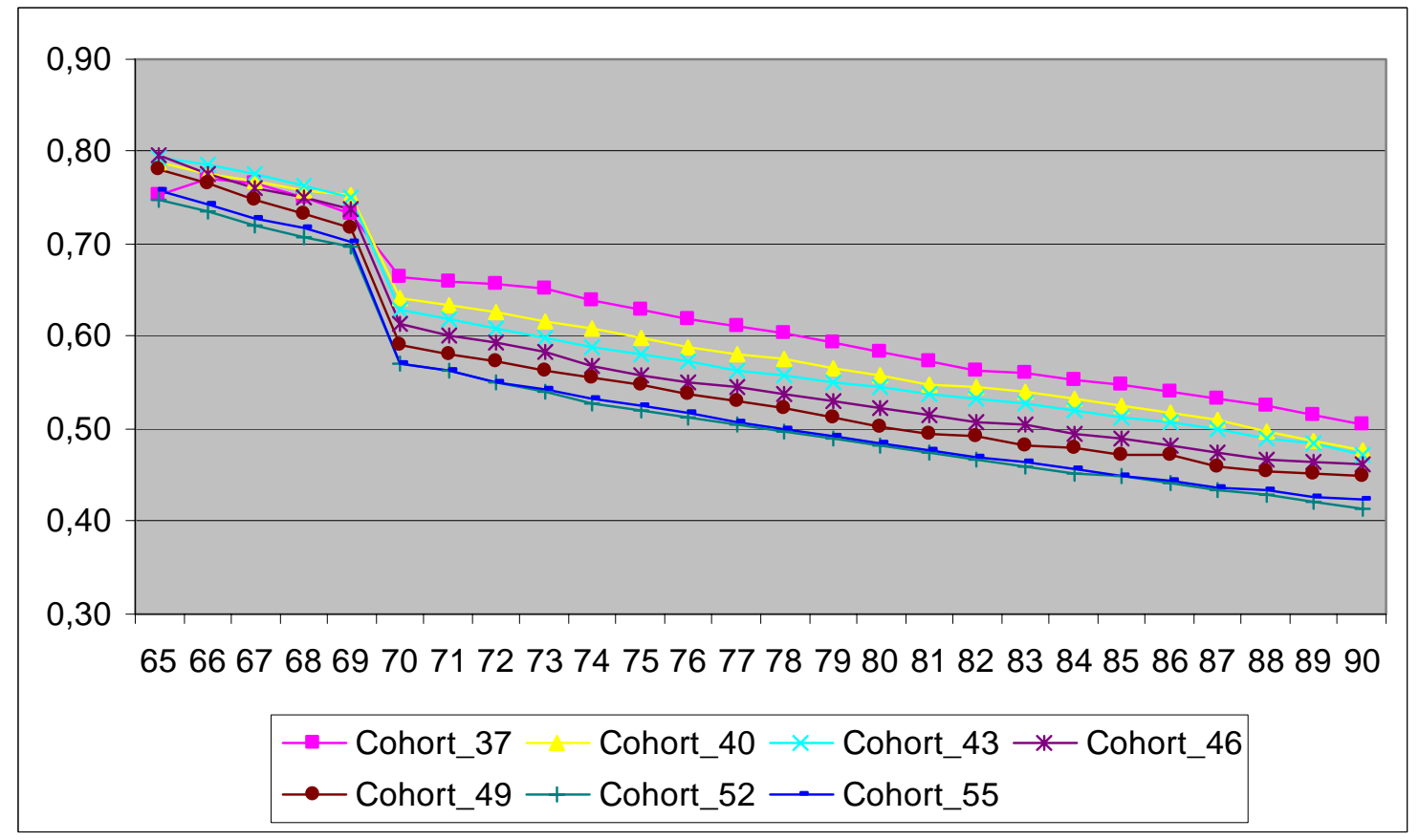


Figure 16. Average taxable incomes by age relative to average taxable income for everyone 20+. A comparison of Linda and SESIM for the income year 2003

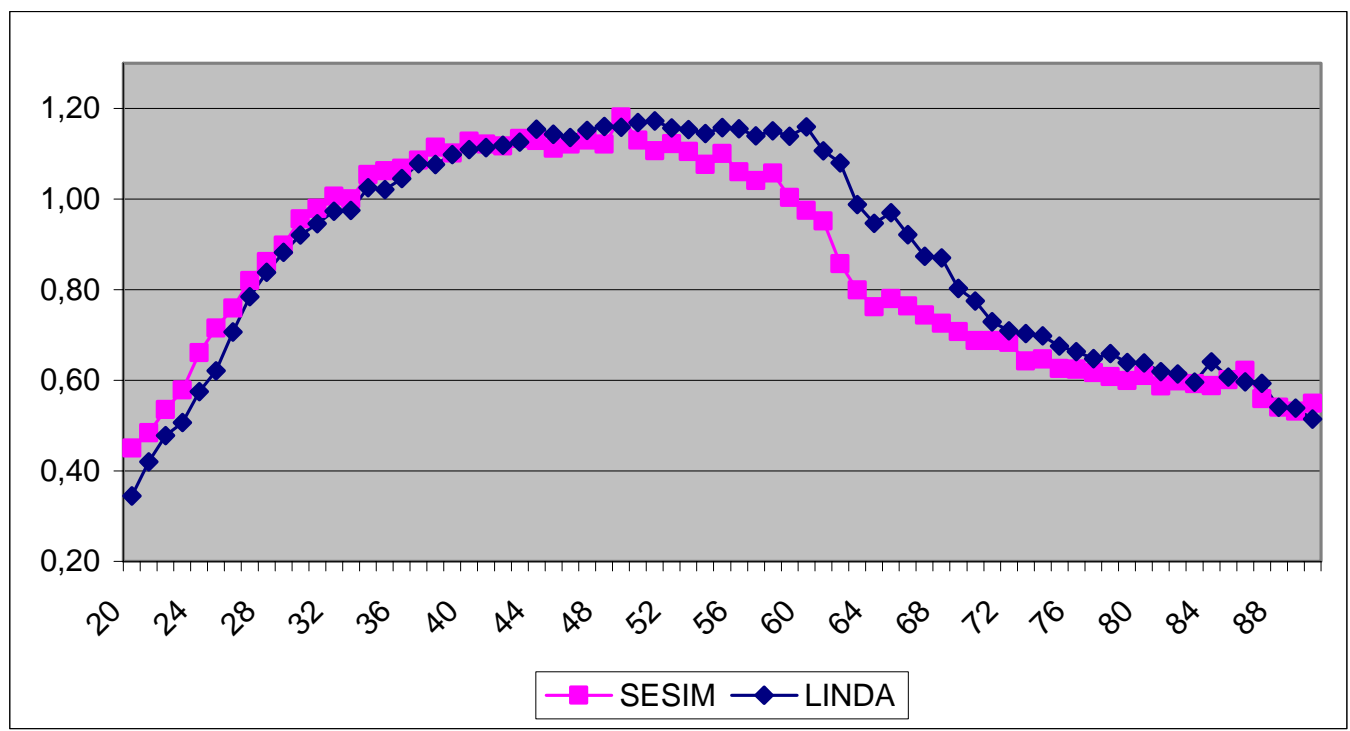

Figure 17. The income distribution of the cohort born in1949 by age. Equalised disposable income (1999 prices)

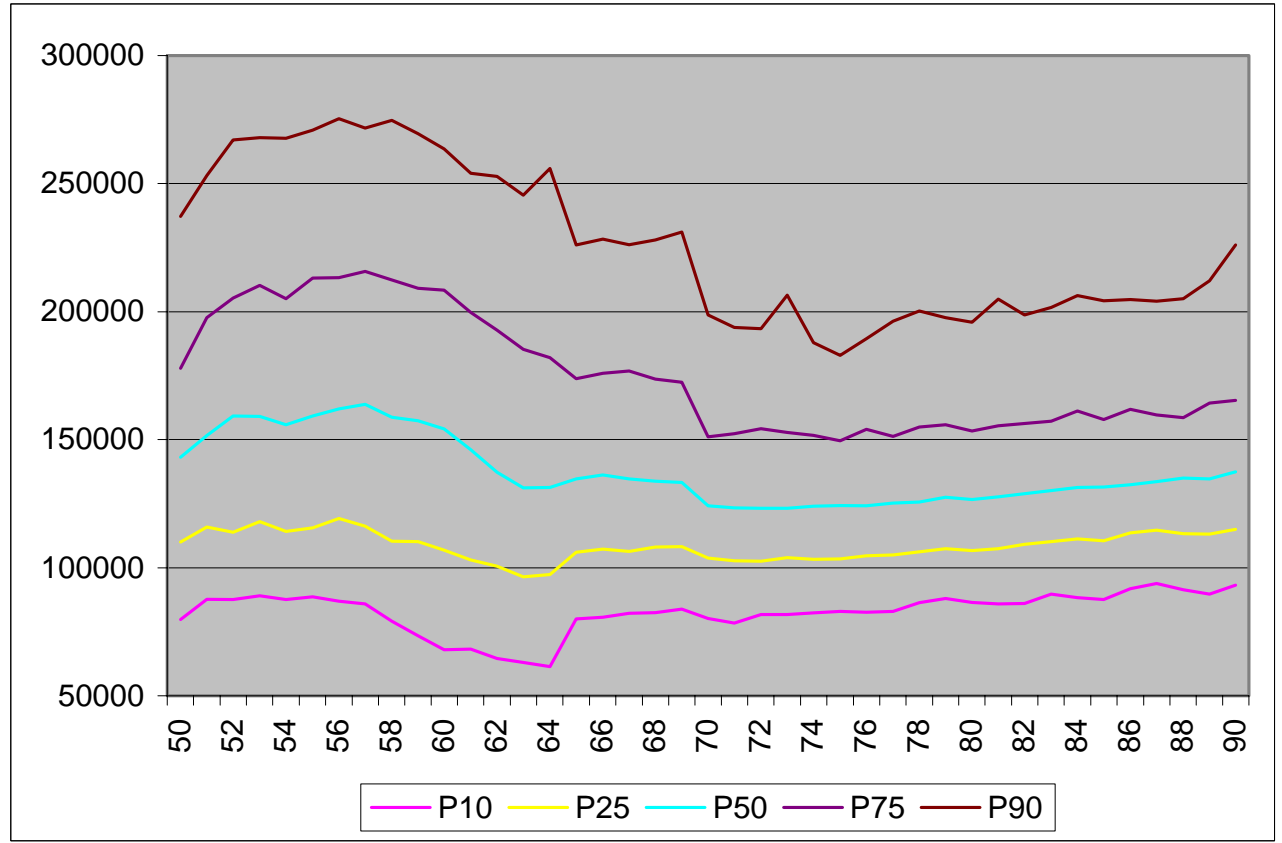


Figure 18. Share of households below the poverty line, by birth cohort and age.

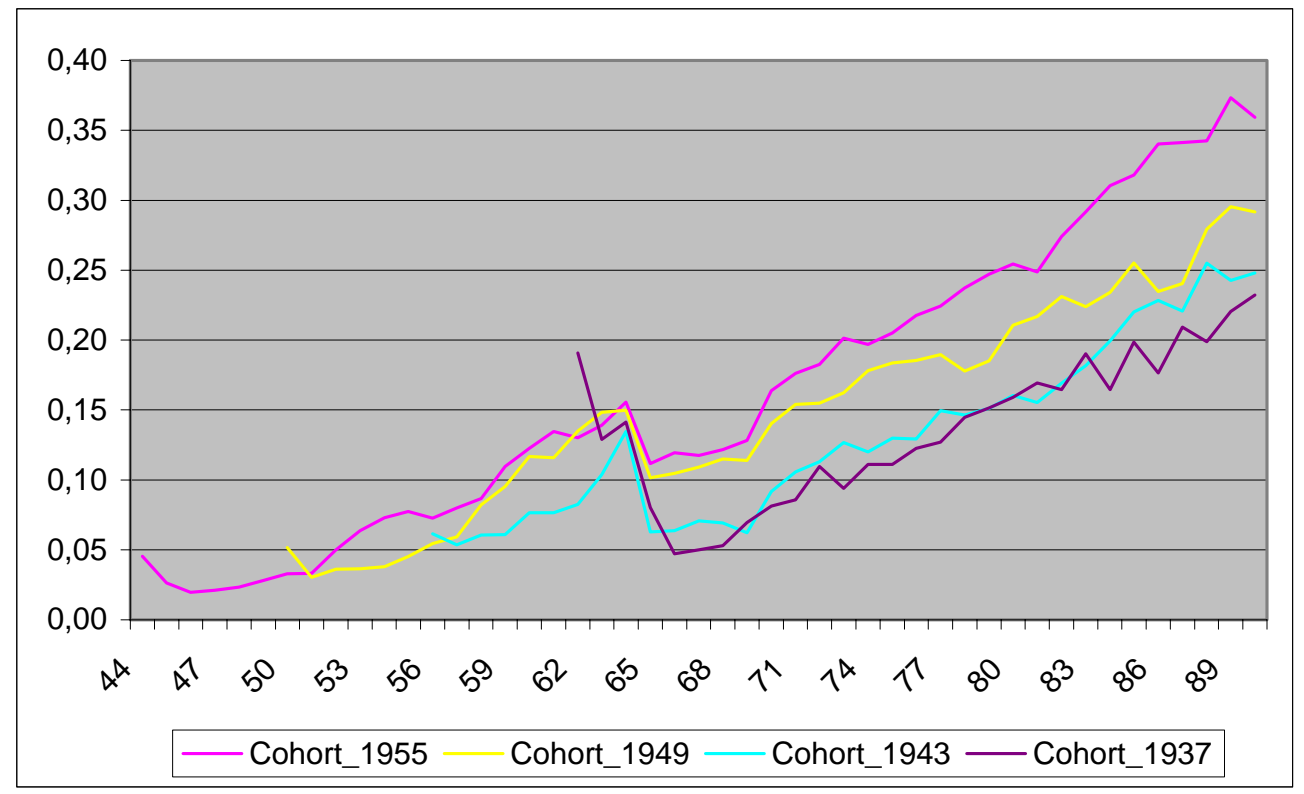

